Portland State University

PDXScholar

1985

\title{
United States policy toward Tunisian nationalism during World War II
}

Martha Staley Marks

Portland State University

Follow this and additional works at: https://pdxscholar.library.pdx.edu/open_access_etds

Part of the History Commons, and the International Relations Commons Let us know how access to this document benefits you.

\section{Recommended Citation}

Marks, Martha Staley, "United States policy toward Tunisian nationalism during World War II" (1985). Dissertations and Theses. Paper 3664.

https://doi.org/10.15760/etd.5548

This Thesis is brought to you for free and open access. It has been accepted for inclusion in Dissertations and Theses by an authorized administrator of PDXScholar. Please contact us if we can make this document more accessible: pdxscholar@pdx.edu. 
AN ABSTRACT OF THE THESIS OF Martha staley Marks for the Master of Arts in History presented Novenber 20, 1985.

Title: United states Policy Toward Tunisian Nationalism During World war II.

APPROVED BY MEMBERS OF THE THESIS COMMITTEE:

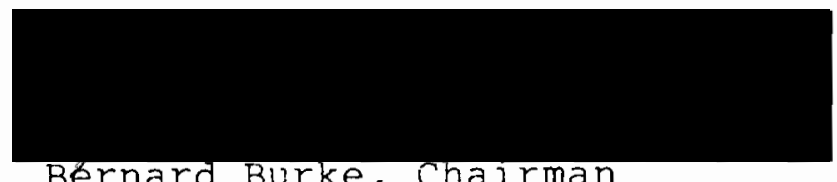

Bernard Burke, Chalrman
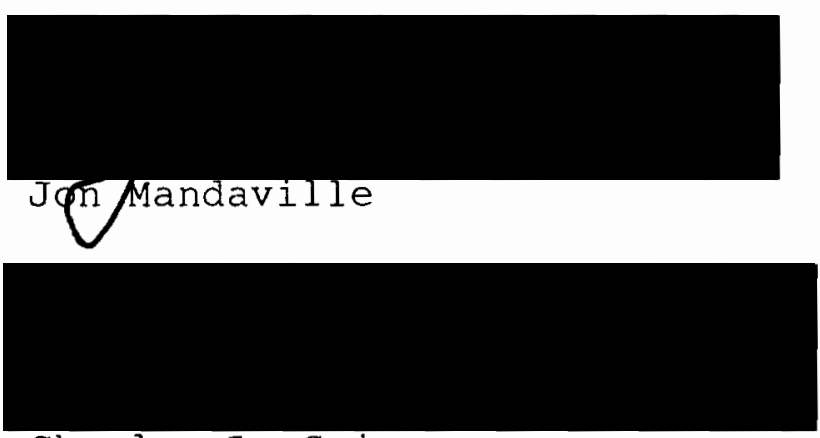

Charles Le Guin

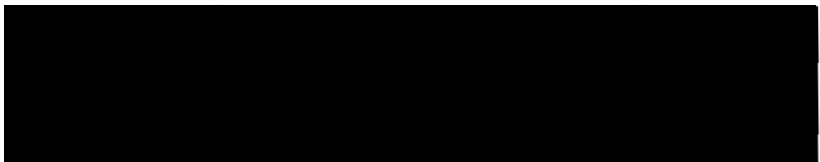

Michael Reardón

This thesis has attempted to describe the controversy between Robert Murphy and Hooker Doolittle over American policy toward the North Africans and French during World War II. The research was based primarily on material from state Department documents found in the National Archives supplemented by material from the French archives as well as 
memoirs, personal interviews, and histories of the period. In order for the reader to understand this particular dispute, the problem was developed in the context of the larger political scene as it evolved in North Africa. The controversy between de Gaulle and Giraud was described since it tended to dominate relations between the United States and France at that time. As a result of the research, it was obvious that Murphy's position prevailed, but not without raising important questions about the long term implications of this position. 


\title{
UNITED STATES POLICY TOWARD TUNISIAN \\ NATIONALISM DURING WORLD WAR II
}

\author{
by
}

MARTHA STALEY MARKS

A thesis submitted in partial fulfillment of the requirements for the degree of

\author{
MASTER OF ARTS \\ in \\ HISTORY
}

Portland state university

1985 
TO THE OFFICE OF GRADUATE STUDIES AND RESEARCH:

The members of the Committee approve the thesis of Martha Staley Marks presented November 20, 1985.

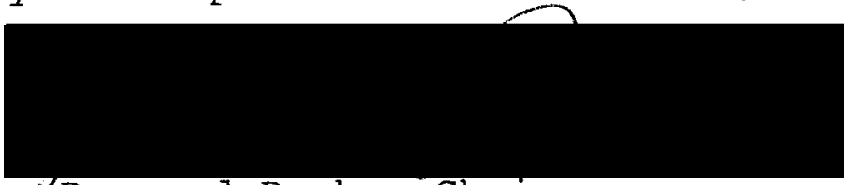

$\checkmark$ Bernard Burke, Chairman

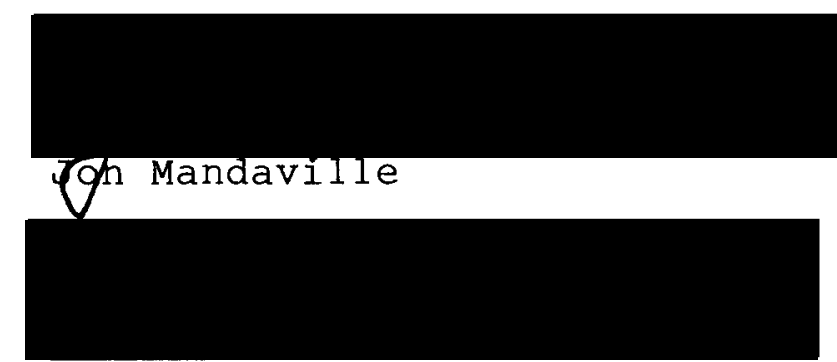

Charles Le Guin

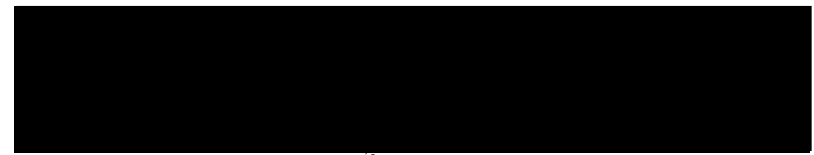

Michael Reardon

APPROVED :

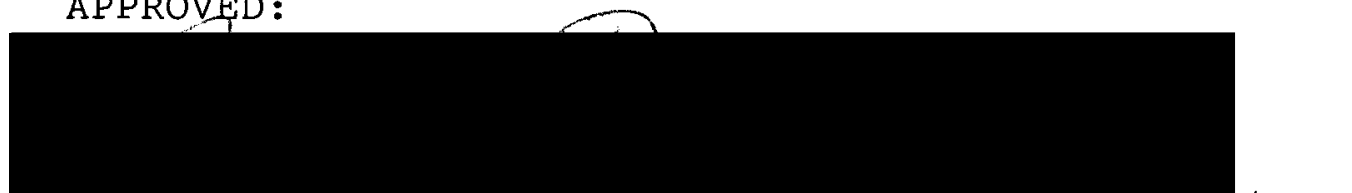

Bernard Burke, Head, Department of History

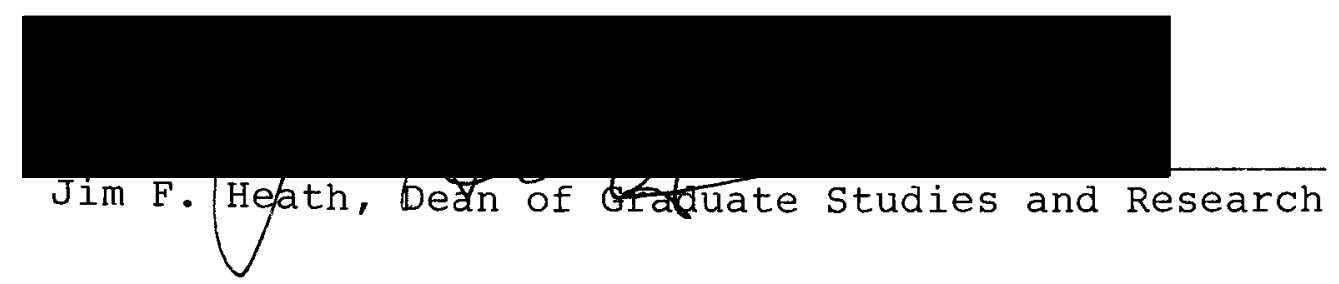


PREFACE

The idea for this thesis came from James $\mathrm{J}$. Dougherty's The Politics of Wartime Aid: American Economic Assistance to France and French West Africa 1940-1946. In Dougherty's book the chapter on "Arab Nationalism and the United States" struck me because of the problems the North African invasion caused American policy makers by raising the hopes of the North Africans for independence. I looked up some of Dougherty's references in the National Archives in washington only to discover that a story unfolded in the despatches from Hooker Doolittle, Paul O'Neill, and Marcel Malige.

Not only was the story interesting, but the strong differences of opinion about the United States policy toward the Tunisian nationalists were similar to those over policy toward Vietnam and Nicaragua. In all three cases there was a reluctance by the policy makers in washington to heed the advice of the diplomats most knowledgeable about those areas and to ignore the basic concerns of the people living there. Instead local concerns have been subordinated to global ones.

I would especially like to thank my adviser, Dr. Bernard Burke, for his help and encouragement. He went beyond the call of duty in reading and re-reading many rough 
drafts of the thesis. Dr. Jon Mandaville let me sit in on his class on Islamic Civilization and gave me some valuable insight into the North African world. I am grateful to the other members of my committee, Dr. Charles Le Guin and Dr. Michael Reardon, for their suggestions about the thesis.

In talking with Paul O'Neill, I learned of things such as the outpouring of emotion in Tunisia at the time of Roosevelt's death, that were not to be found in the Archives. Marcel Malige was kind enough to write answering my questions and describing his impressions of Bourguiba.

Doolittle's daughter, Katya Coon (Mrs. Maurice Coon), spent a day with me at her home in Marshfield, Massachusetts and gave me material that was otherwise unavailable. Her sister, Natasha Van Deusen (Mrs. E.R. Van Deusen), filled me in on her recollections of Doolittle's meetings with Bourguiba in Alexandria. Katya Coon's daughter, Elena Prentice, who lives in Paris, contacted people for me to meet or talk with who had been in Tunisia during the war.

Sabine Vauclain arranged for my husband and me to exchange our house for Yves and Andrée Haas' apartment in Paris making it possible for me to do research at the Bibliotheque Nationale and at the Ministere des Affaires Étrangeres. Andrée Haas, whose first husband was killed at Toulon fighting with the Free French, introduced me to Suzanne Broche, whose husband had also been with the Free 
French and had been killed in the fighting at Bir Hakeim. Madame Broche, who had grown up in Tunisia, shared with me her memories of the war years in Tunisia, especailly those under German occupation. Yves Haas, another former Free French fighter, explained how there were very few Frenchmen joining the de Gaulle forces at the beginning. Tamara Kinski, whose family had immigrated to France from Tiflis, Georgia at the time of the October Revolution, remembered seeing Hooker Doolittle in Egypt with his wife, who had also come from Tiflis. Tamara's father, a member of the French Foreign Legion, was killed fighting with the Free French at El Alamein. Tamara helped me to understand differences in French politics and offered to introduce me to Madame Mast, who was unfortunately away from Paris.

Estelle de Montgoflier of Avignon, France, whose parents were French doctors in Tunisia, described many aspects of Tunisian culture. Woods Vest helped find the addresses of Katya Coon and Marcel Malige.

Stuart Gates of Portland, who knew Doolittle in Tangiers, found two pictures of himself and Doolittle when they were both living in Tangiers which he had reproduced for me, one of which is included.

My brother, Allen Staley, and his wife, Etheleen, let me stay in their house while I worked at the Hyde Park Iibrary and my brother had many useful suggestions about writing the thesis. My daughter and her husband, Martha and Carter Wormeley, let me combine visiting with them and doing 
research at the Archives and Library of Congress. Sally Marks, Kathy Nicastro, and John Taylor were helpful at the Archives and have subsequently found documents for me. My husband, John, has helped me with making the thesis more readable and has let the thesis take precedence over other activities. 
TABLE OF CONTENTS

Page

PREFACE . . . . . . . . . . . . . . . i ii

LIST OF FIGURES . . . . . . . . . . . . . v viii

CHAPTER

I INTRODUCTION . . . . . . . . . . . 1

II FALL OF FRANCE . . . . . . . . . . 5

Notes . . . . . . . . . . . 34

III TUNISIAN BACKGROUND . . . . . . . . . 38

Notes............ 58

iv PALACE REVOLU'TION • . . . . . . . . 61

Notes............. . 84

$\mathrm{V}$ OPERATION TORCH . . . . . . . . 88

Notes............ 123

VI GIRAUD-DE GAULLE CONFLICT . . . . . 128

Notes . . . . . . . . . 155

VII RECALL OF DOOLITTLE . . . . . . . 158

Notes........... 210

VIII TUNISIA AFTER DOOLITTLE . . . . . . 218

Notes............. 259

BIBLIOGRAPHY . . . . . . . . . . . 265 


\section{LIST OF FIGURES}

\section{FIGURE}

PAGE

1. Hooker Doolittle and Stuart Gates of Portland, Oregon leaving the Anglican Church in Tangier. . ix 2. Map of North Africa. . . . . . . . . . . . $\mathrm{x}$ 


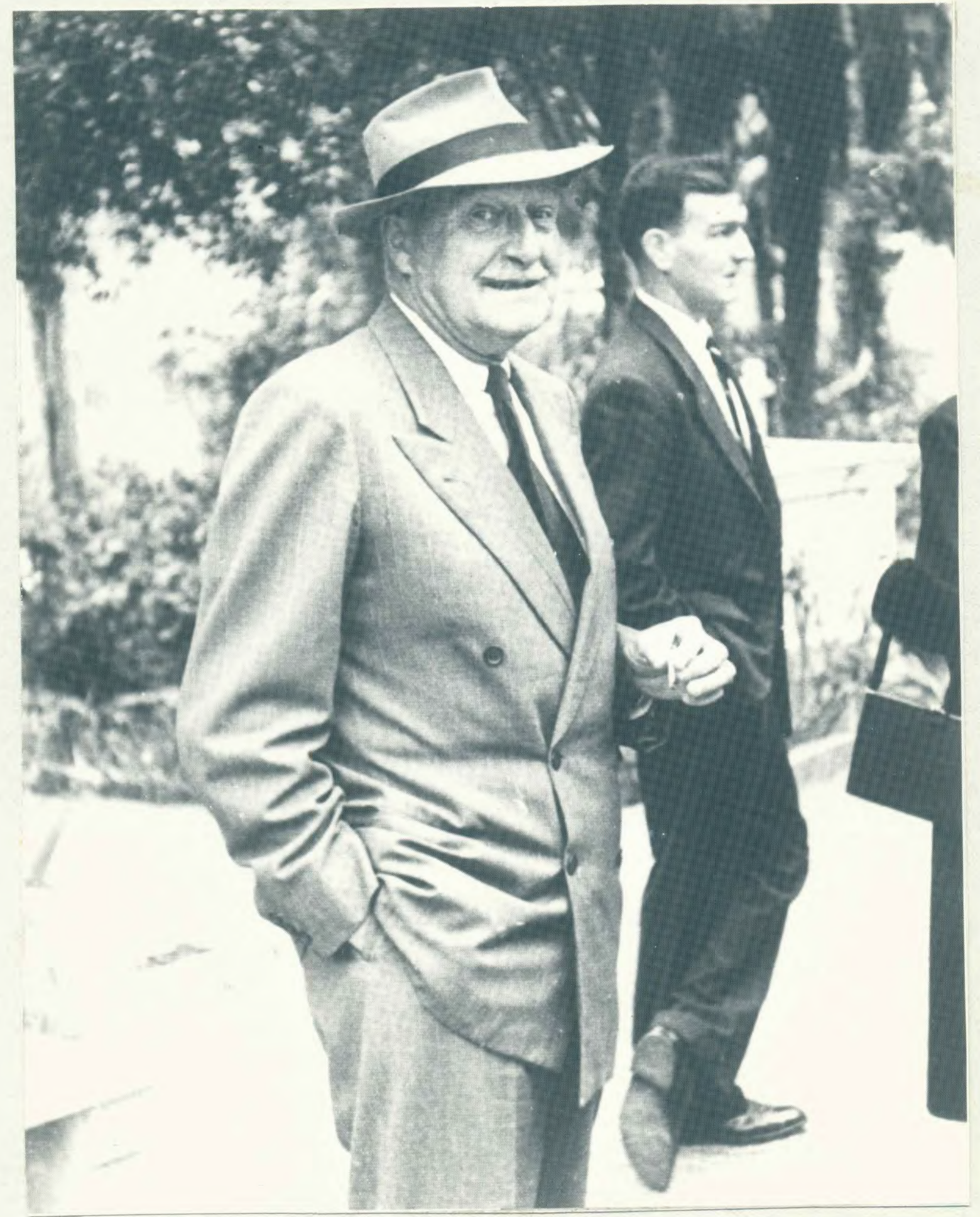

Figure 1. Hooker Doolittle and Stuart Gates of Portland, Oregon, leaving the Anglican Church in Tangier. 


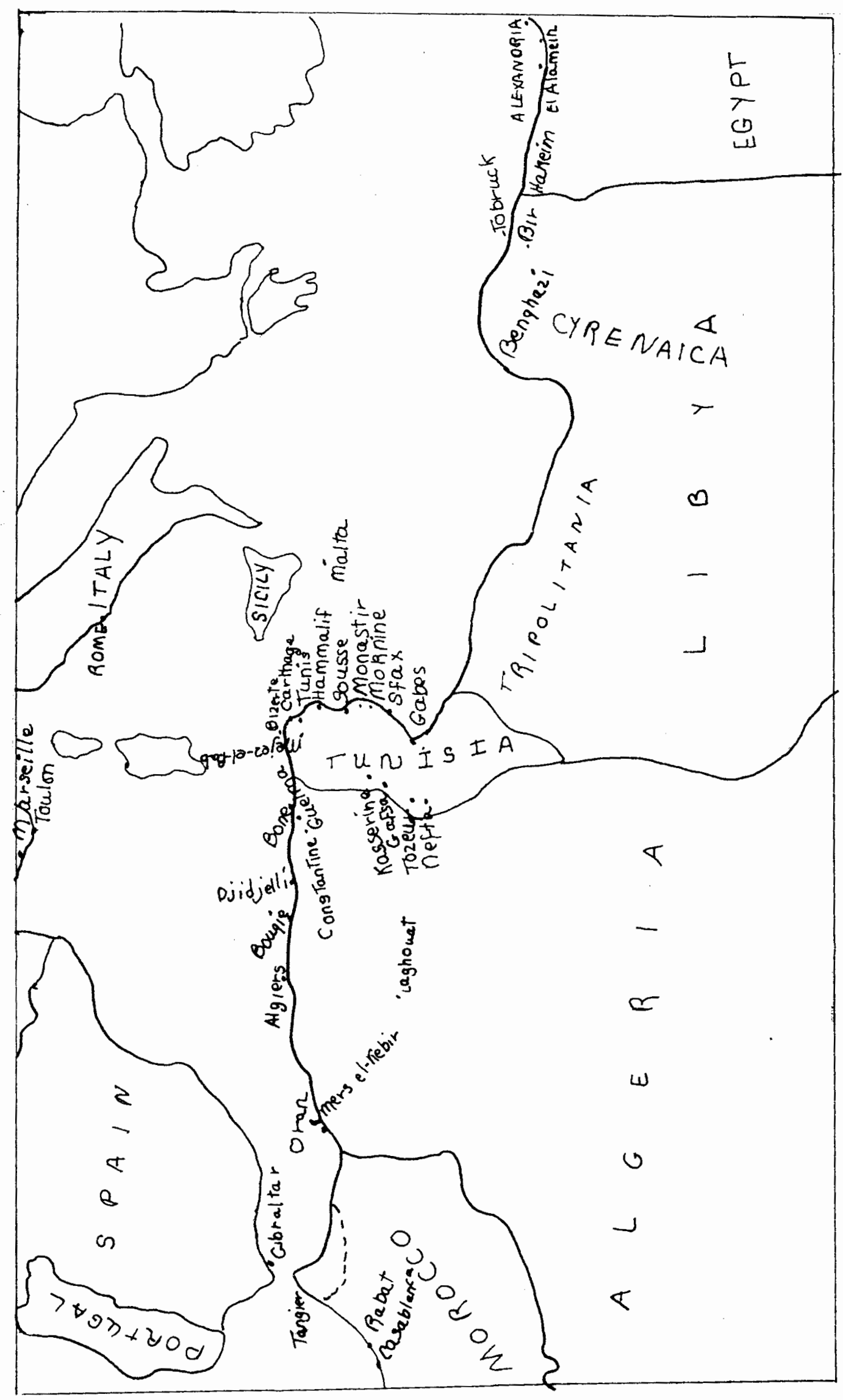




\section{CHAPTER I}

\section{INTRODUCTION}

A conflict arose in Tunisia during World War I I among State Department representatives over the United states response to the Tunisian independence movement. Hooker Doolittle, the American Consul General in Tunis, was aware of and sensitive to Tunisian nationalism. He reported it in numerous letters to the state Department. Robert Murphy, Civil Affairs Officer on General Dwight Eisenhower's staff, on the other hand, thought any recognition by the United States of nationalist desires of the North Africans would jeopardize relations with the Erench.

Eisenhower backed Murphy because French cooperation had been important not only in preparation for the North African invasion, but afterwards for its administration. Eisenhower wanted the French to administer the area in order not to tie up his forces in the responsibilities of an occupation army. Anticipating the landing of the Allied Expeditionary Force in France, Eisenhower was well aware that French cooperation would be equally important there.

For the French, humiliated by their recent defeat, it was important to hold on to their Empire, for it along with their navy and the unoccupied portion of the mainland was 
what remained to them to use as bargaining chips with the Germans. Later when German defeat seemed probable, they needed the Empire to regain their great power status.

After United States and British troops had landed in North Africa and driven the Germans out, the French resorted to harsh and repressive measures against the North Africans to regain the upper hand. In Tunisia they went so far as to depose the Bey. They claimed he had collaborated with the Axis, but the real reason was his support of nationalist goals.

Doolittle, aware of the injustice of this step as well as the French mistreatment of the Tunisians, urged the state Department to intervene with the French and attempt to influence them not to depose the Bey and to ameliorate their treatment of the Tunisians. He realized that American prestige which had been high with the North Africans at the beginning of the war was suffering from these French actions. The North Africans were holding the United States accountable as allies of the French. In some cases the French were saying that they were carrying out repressive measures at the request of the Anglo-American command. Doolittle, furthermore, thought the united states should uphold the principles of the Atlantic Charter, or as his daughter said in an interview, he thought America should stand for something.

Unfortunately for all concerned, Murphy saw only the French position. He had worked in France before the war. In 
preparation for the North African invasion, he had worked with members of the military and other French in North Africa. By his own admission, he knew nothing about the North Africans. He only knew that any suspicion of American encouragement for North African goals of independence upset the French.

It was because Doolittle had upset the French by his Tunisian sympathies that Murphy asked the State Department for his recall. Doolittle's position was not without supporters in the State Department. Among these was Edward Stettinius, who was serving as Acting secretary of state at the time. Stettinius and others thought that Doolittle's point of view was of sufficient importance to the United States that President Roosevelt should hear it. Thus it was that Doolittle had an interview with the President. Unlike Murphy, Roosevelt was sympathetic with the North Africans, but no policy changes resulted from the interview. If anybody could have effected a change in United States policy, it was the President, but he declined to do so. Undoubtedly he did not intervene because he wanted to back up Eisenhower. Also, Roosevelt had appointed Murphy as his personal representative to report directly to him. Having initially by-passed the state Department and relied on Murphy for political advice about North Africa, Roosevelt probably did not want to oppose Murphy's decision in the Doolittle dispute.

Furthermore, the Doolittle matter came to his 
attention at a time when he was preoccupied with another controversy - that between General Charles de Gaulle and Henri Giraud. Roosevelt had been troubled by this dispute since the landings and at the time of Doolittle's recall it was at one of its crisis points. With Giraud's eventual elimination from the political picture, the de Gaulle-Giraud conflict was settled, but not the conflict between Roosevelt and de Gaulle. This would last until Roosevelt's death. Its consequences on French-American relations have probably lasted until today. Ignoring North African concerns has produced consequences that are less well known, but have been important ever since. Americans lost some good will and were seen as partisans of French colonialism. Could the United states have done any differently under the circumstances? To understand how American actions evolved in Tunisia, it is necessary to look at American relations toward the French from the beginning of the war. 
CHAPTER I I

FALL OF FRANCE

The fall of France brought about changes in French leadership. One of the American responses to this new leadership was an increased interest in North Africa.

On May 14, 1940 the Germans broke through the French lines at sedan. The invasion was not unexpectea since both France and England had declared war on Germany on September 3, 1939 after the latter had attacked Poland. Even with British help, however, French troops were no match for the well prepared Germans with their heavy tanks and dive bombers. French Premier Paul Reynaud and his recently appointed under-Secretary of state for War, Charles de Gaulle, were determined to continue fighting, but there were others in the military and government that considered the French position hopeless and thought the French should seek an armistice. Among these were Marshal Henri Pétain, the new Minister of War, and General Maxim Weygand, who had been called from his post in syria on May 19 to take charge of the faltering French army. There was little Weygand could do to reverse the situation. Part of the French and British forces were trapped at Dunkirk and hac to be evacuated across the chanenl in a dramatic rescue operation. The 
British and French navy as well as numerous small boats brought two hundred and sixty thousand British and ninety thousand French to England. With his troops severely reduced, Weygand was unable to withstand the German advance toward Paris. To make matters worse, the Italians declared war on France June 11 crossing the Italo-French frontier in the south. This "stab in the back" was bitterly resented by the French and would later cause problems for the Italians in Tunisia.

Reynaud pleaded with both winston' Churchill and Franklin Roosevelt for help. The latter could offer only material and moral support as Congress alone could declare war, and it was not prepared to do so at that time. As for Churchill, Reynaud beseeched him to send more planes. On June 9 Reynaud expressed to United States Ambassador to France William Bullitt his disappointment with the English:

in spite of eleven telegrams and seven personal telephone conversations he had been unable to persuade Churchill to put into the present battle more than one fourth of the British pursuit planes. (1)

Churchill, anticipating the need for planes for England's own defense, felt that he could not send more.

Churchill's refusal to send more planes reinforced the position of those like Pétain and weygand who wanted an armistice. Petain told Bullitt that he thought England would allow Germany to defeat France and then make a compromise peace. (2) Reynaud, however, had promised Churchill that as long as he remained premier, "France would fignt to the 
bitter end." (3) He felt honor bound to the pledge both countries had jointly made in March not to sign a separate armistice or peace without the prior consent of the other. (4) Nevertheless, on June 13 when Churchill came to Tours to which the government had retreated when the Germans reached the outskirts of Paris, Reynaud asked him what the English reaction would be should France be forced to ask for peace terms. Churchill replied:

We shall not heap reproaches on an unfortunate ally and if we are victorious, we assume the unconditional obligation to raise France from her ruins. (5)

As sympathetic as Churchill's response was, he could not answer for his government. After his return to England and consultation with the cabinet, churchill sent a proposal to the French, that the two countries form a union. Having had to move farther south to Bordeaux on June 14, the French cabinet was in too great a state of confusion to consider seriously this innovative and generous offer. While it rejected this proposal, there were those who wanted to hold out in a "Breton redoubt" while others favored moving the government to North Africa. The majority, however, wanted an armistice. Lacking the support of the cabinet in his determination to fight on, Reynaud stepped down on June 17 in favor of Pétain, who immediately sought peace terms with the Germans. A ship carrying a group of French deputies, including Pierre Mendes-France, actually sailed for Morocco. Unfortunately by the time they landed, the government in France had changed and they were put under arrest on their 
arrival.

General August Nogùes, Resident General of Morocco and Commander-in-Chief of the North African troops, wanted to continue the fight. He sent a message to Weygand urging him not to stop lest France "lose forever the esteem and confidence of the indigenous people." (6) He himself was ready to continue the fight and was ready to enter into dissidence if he was authorized. In a cable to Petain he warned that if France did not defend North Africa, she would have trouble maintaining her authority "for one doesn't govern in scorn." (7) Weygand found the idea of continuing the fighting "absurd" and "odious". (8) In Tunisia, too, according to Charles Heisler, the American consul there, the French had wished to continue the struggle. When Marcel Peyrouton, the Resident General there, accepted the armistice, it was not popular. Nor were the British popular as the French in Tunisia thought they had not aided France sufficiently.

pétain at 84 was known as the hero of verdun. While there were questions whether this tribute was deserved, there were even more about his treatment of Reynaud and other members of the previous administration who were arrested and imprisoned. The new cabinet needed a scapegoat for the defeat and what was more natural than to blame the previous cabinet. In letters to pétain from prison, copies of which managed to go to Roosevelt, Reynaud questioned petain about why he was accusing him, Reynaud, of being 
responsible for losing the war when it was really petain who had vetoed his plan of using tanks. Reynaud reminded petain that he had for years "tried to open the eyes of Parliament to the deadly peril that threatened our country." (10)

While Reynaud and others were unjustly accused, there was a tendency throughout France to blame the Third Republic with its parliamentary type government and ever changing premiers for the national disgrace. This climate of opinion seemed to call for a more authoritarian government. on July 10 the Chamber of Deputies gave full powers to Pétain and made him the head of the French state. This new authoritarian government instituted what was called the "national revolution", with the slogan "work, family and country". The national revolution was a revolution from the top with all power coming from the state. Above all it represented a shift to the right bringing to power an element in France that was both nationalistic and intolerant of minorities. Freemasons, Jews, and socialists were looked upon with suspicion. This aspect of French politics had been seen before in the persecution of Dreyfus and has been seen since in the recent gains of the National Front in the 1984 election for the European Parliament.

While vichy was characterized by internal authoritarianism, externally it was characterized by its collaboration with Adolph Hitler. By the armistice terms Hitler had left France with a semblance of sovereignty. Though Germany occupied three-fifths of France, the 
southeastern part was left free and established itself at the spa town of Vichy whose hotels were used for government offices. Hitler also allowed France to keep her fleet, her colonies and to maintain an armistice army. A France that seemed sovereign saved Germany from the job of total occupation and of keeping order in its rear during the contemplated assault on England.

While there were those in Petain's government such as weygand who were fiercely anti-German, there were others who thought that France's future lay with the Germans. Among these were a group of French financiers and industrialists called the Banque Worms whose business interests would best be served by a German victory. Organized into a political pressure group, the Banque Worms took its name from the parent organization Worms et Cie., a banking house which had long standing German connections through its heavy industry interests. This group wanted complete political and economic collaboration with Germany and to encourage a negotiated peace between Germany and England should the opportunity occur. Instead of operating as a party, it insinuated its members into the most important political positions. Two members of the group who held posts in the vichy government were Paul Baudouin, Minister of Foreign Affairs, and Pierre Pucheu, Minister of the Interior. (11)

Pierre Laval, a former deputy and one time prime minister, came into the government without portfolio. According to Weygand, he persuaded Pétain not to make Laval 
foreign minister because of his hatred of the British. Soon, however, Laval, an astute politician, became the dominant member of the cabinet with the title of vice-premier and exerted a strong and, as Weygand called it, "pernicious" influence on petain. (12) While Laval was above all for France, he preferred her destiny to be linked with Germany rather than with the Anglo-Saxon countries. He expected Germany to win the war and hoped that France would be a favored part of the new German order. To insure her post-war position, she needed to co-operate with Hitler during the war. In a talk on July 30,1940 with Robert Murphy, the United states chargé d'affaires, Laval said that a German had quoted the Axis representative at Paris as saying that the Germans did not expect to crush France, but they planned

a European federation of states in which France will play an important role compatible with its dignity and tradition. (13)

And further:

speaking personally and off the record, he [Laval] said he had announced it before and did not hesitate again to say 'that he hoped ardently that the English would be defeated.' (14)

In pursuit of his policy laval arranged a meeting between Hitler and pétain to discuss closer French-German cooperation against England at Montoire-sur-Loire on October 31 and November 1, 1940. As a result of this meeting, Hitler left it up to the French to defend themselves against the English in North Africa. In spite of Laval's success in arranging this meeting, petain was dissatisfied with him and 
dismissed him from his cabinet in December. Laval treated Pétain with disdain. Pétain feared that Laval intended to make him a figurehead and make himself head of state.

pétain now showed increasing confidence in Admiral

Francois Darlan, his Minister of Marine, who by February was appointed vice-premier and "heir apparent" to the Marshal. (16) Darlan probably hated the British as much as Laval if not more. As a navy man Darlan resented the limitation that had been put on the French navy at the Washington Naval Conference in 1922 when France had been allotted the same number of ships as Italy, below that of England, America, or even Japan. In case he inight have overlooked this slight, he could never forgive the British for the Mers-el-Kebir incident. A large part of the French navy in order to escape from the Germans had fled to the port of Mers-el-Kebir in Algeria. In spite of assurances from Darlan that the fleet would be scuttled rather than be allowed to fall into German hands, the British were not completely convinced. Feeling they could not risk such an eventuality, the British on July 3, 1940 sent an ultimatum to the French admiral in charge of the ships at Mers-el-Kebir demanding that the fleet proceed either to Britain, the West Indies, or to a United States port to be interned. When the French admiral refused, the British opened fire on the ships putting many out of commission and killing over one thousand Frenchmen.

This incident reinforced the anglophobia of Darlan and 
of the French navy. It did not help any French feeling toward their former ally, and it particularly embittered the French in North Africa, some of whom had watched the ships burning from the nearby city of oran. The damage done to French-British relations by Mers-el-Kebir was enormous. The French cabinet was so angry that Foreign Minister Baudouin even wanted France to join Germany in the war against England. (17) while pétain restrained the cabinet from taking this step, it did break diplomatic relations with Britain two days later. Pétain attributed Mers-el-Kebir "to the snap judgment of 'winston Churchill who is capable of almost any rash act when drunk as he frequently is." (18) Hating the British need not, however, have meant actively pursuing the policy of collaboration which Darlan embarked upon. Like Laval, Darlan was confident that the Germans would "win the war and establish a new order in Europe." (19) Darlan envisioned a new continental system in which France would be a naval and imperial power. He thought a German victory which would weaken England would help bring this about. (20) Darlan's policy of collaboration culminated in May 1941 with the signing of what were called the Paris Protocols, which gave the Germans the use of Syrian airfields, the use of Bizerte in Tunis for General Erwin Rommel's Afrika Corps and a future submarine base at Dakar. (21) Unlike Laval, who never wavered from his pro-German stance, Darlan, considered an opportunist, would later switch his allegiance. He preferred to be on the 
winning side. When Germany invaded Russia in June 1941, he probably realized that a German victory was less certain.

At the time of the armistice there was one member of Reynaud's cabinet whose allegiance was beyond question. Charles de Gaulle, who had just been promoted to General, was bitterly opposed to the armistice. Later he managed to escape to England and there he appealed to other Frenchmen to join him to continue the fight against the Germans. At that time de Gaulle was relatively unknown, though during the 1930's he had written a book advocating the use of tanks as an important element in French military strategy. While Premier Reynaud had favored the idea, he had not been able to bring the rest of the government to implement the proposal. It was said that Hitler made use of de Gaulle's ideas in modernizing the German army. During the Nazi invasion de Gaulle had fought well in the north of France and had been commended by weygand for his efforts there. On meeting him Bullitt wrote Roosevelt that this general, who had two weeks before been a colonel in the tank corps, had "showed great initiative and courage in stemming the German advance on Paris." (22) He found that he was a young man who appeared "vigorous and intelligent." (23) He was thus known as a sound military thinker and a good soldier, but he did not have the prestige of heroes of the first world war such as Pétain and weygand. The pétain government, considering him a traitor for breaking with them and leaving for England, condemned him to death in absentia by a military 
tribunal August 2, 1940.

While churchill decided to support de Gaulle, who was the only Frenchman rallying others to the side of Britain, very few French leaders who had left France joined de Gaulle at this time. Some of the soldiers who had been evacuated at Dunkirk stayed on and became part of the Free French Divisions while gradually others came from France and the colonies. Eventually the Free French had two divisions, one of which fought alongside the British in Libya against Rommel while the other went to Syria before going to North Africa.

With the British radio at his disposal, de Gaulle was able to encourage the mainland French and gained stature with them. Slowly a resistance developed in France with many members who looked toward de Gaulle as their leader. He also won the adherence of several of the colonies including chad and the Cameroons.

In North Africa, however, de Gaulle was looked on with distrust. He was seen as too closely connected with the British, the perpetrators of Mers-el-Kebir. His movement was even thought to serve as a screen for British imperial ambitions. This suspicion was strengthened when de Gaulle and the British joined forces in september 1940 in an attempt to take over Dakar. The British wanted Dakar in order to protect British shipping. Although de Gaulle thought the Dakar garrison would rally to him, instead they put up a stiff resistance resulting in French killing 
French. The attackers were turned back. Not only was the invasion a failure, it increased anti-British hatred among the French. It also increased their distrust of de Gaulle and the Free French. One of the causes of the defeat seemed to have been that the Free French had talkea about it in London too openly. From that time on, Churchill considered them "leaky" and was hesitant to inform them of any plans in advance. This was true of both the North African invasion as well as that of the European continent.

A similar situation occurred ten months later in June 1941 when the Free French and British attacked Syria to prevent Darlan from turning over syrian airfields to the Germans. Again there were French fighting French, which did not endear de Gaulle to the French in North Africa.

Weygand used these attacks by de Gaulle to extract more troops from Hitler in order to build up the armistice army. The French military officers in North Africa were determined to keep both the British and Germans out of this area. To allow either to enter would bring reprisals from the other. It was because Hitler had been so impressed by the French defense at Dakar that he had agreed to the meeting at Montoire.

For his part it was because of Montoire that de Gaulle in October made a declaration at Brazzaville that Vichy was no longer legitimate. De Gaulle thought that the collaboration of Vichy with the enemy had been officially proclaimed at that meeting. (24) He took upon himself the 
responsibility of looking after the interests of France. He promised to give an accounting "to the sovereign

people . . When liberty was regained." (25) Having started as a purely military movement, de Gaulle's Free French had become a political one as well.

While relations between de Gaulle and Churchill were often difficult, they endured for the length of the war. Churchill not only wanted these Frenchmen fighting alongside the British, he wanted the strong post-war France that de Gaulle envisioned. A strong France, of course, meant to both men a France with her empire intact.

President Franklin Roosevelt and Secretary of state Cordell Hull had quite different ideas about de Gaulle and the ultimate disposition of the French Empire. As for de Gaulle, the United States could not recognize his movement so long as it continued to maintain relations with vichy. Besides, in the summer of 1940 de Gaulle was still an unknown quantity. De Gaulle made sure that he did not remain unknown, but his ways of asserting himself and his movement often resulted in his alienating not just Roosevelt and Hull, but even Churchill.

Underlying personality clashes and difficulties over recognition were fundamental differences between Roosevelt and Hull on the one hand and Churchill and de Gaulle on the other over the question of colonialism. While more has been written about Roosevelt's differences with Churchill on this question, de Gaulle shared the latter's belief in Empire and 
was considered by Roosevelt and Hull to be an ally of

Churchill on this point. A major goal of the foreign policy of de Gaulle as well as of the Vichy French after the defeat of 1940 was to maintain the French Empire. Roosevelt could not forgive the French for failing to resist the Germans in Europe and the Japanese in Indochina. He felt France did not deserve to have colonies such as Indochina returned or to play a great power role in the post war world.

While Roosevelt had not always been anti-imperialist, by 1928 he had come to the conclusion that a new world based on self-determination was needed. In Foreign Affairs he wrote:

The time has come when we must accept not only certain facts but many new principles of a higher law, a new and better standard in international relations. We are exceedingly jealous of our own sovereignty and it is only right that we should respect a similar feeling among other nations. (26)

By the time he became president in 1933, his anti-colonialism was well established and never altered until his death.

There were political as well as humanitarian reasons for his stand. With the outbreak of the war and American aid to Great Britain, Roosevelt realized the American public needed to be reassured that aid to the British was not for the purpose of perpetuating the British Empire. Roosevelt arranged to meet with Churchill to discuss aid and at the same time clarify for American public opinion the principles at stake in the war. Out of their meeting at Argentia, Newfoundland in August 1941 came the Atlantic Charter, which 
stressed the humanitarian goals of the war. Article III pledged respect for the right of all people to choose their form of government. While Churchill gave his assent grudgingly, differences in interpretation of the Atlantic Charter between the two heads of state surfaced shortly after the meeting. Roosevelt was never successful in changing Churchill's views about Empire. This was apparent in the latter's remark in 1945, "I did not become Prime Minister to preside at the liquidation of the British Empire." (27)

Cordell Hull's anti-imperialism also went back a long way. As a Congressman from Tennessee, he had become a student of tariffs and his ideas on tariffs had led him from the national to the international sphere. He became an exponent of free trade and as early as 1914 was opposed to the idea of preferential trade or the empire system. In his Memoirs he wrote: "Back in my Congressional years I had stood against imperialism and colonial expansion." (28) Even before the United States entered the war, Hull, as Secretary of State, felt the united States would be confronted with the need to establish a stable world order. In those days of non-belligerence he appointed a committee in the state Department to analyze the post-war consequences of the policies of the warring nations. After the United States entered the war, the committee turned to planning for a post-war organization that would maintain peace by collective security rather than the balance of power. 
Although Roosevelt and Hull were at least as distant from Vichy as from de Gaulle in terms of their views on imperialism and a world order, they devoted much more effort to getting along with the former than they did with the latter. The American president and his secretary of state had some specific objectives they thought could be achieved by this policy. Above all they wanted to keep the French fleet and Empire from falling into German hands. As a former Under-Secretary of the Navy during World war I, Roosevelt was particularly sensitive to naval problems. As early as May 26, 1940, he had instructed Ambassador Bullitt to tell Reynaud that the United States

considered retention of the French fleet vital to the reconstitution of France and her colonies and to control of the oceans and to getting less harsh peace terms. (29)

Churchill was given the same message about the English fleet. Both Churchill and Reynaud promised that the fleets would never be surrendered. According to Weygand, there was never any question on the part of the French of relinquishing either fleet or colonies to the Germans. The ministers had agreed that armistice negotiations would be broken off if the Germans demanded surrender of the fleet or any part of the overseas territories. (30)

In spite of these reassurances the United States remained concerned. With the armistice there was only the British fleet between America and Germany. It was known that British land defenses were weak, and there was even a 
question of whether the British fleet could withstand the Germans. This depended to some extent on the French. If the Germans were able to use the French fleet, England would have even less of a chance, thereby affecting United states security. Bullitt wrote Roosevelt

I believe as strongly as I have ever believed anything that you will be unable to protect the United states from German attack unless you have the cooperation of the French and British fleets. (31)

On June 17 Admiral Darlan was told that if the fleet was surrendered to Germany, "France will permanently lose the friendship and good will of the government of the united states." (32) On June 23, several hours before the signing of the armistice, Darlan gave orders, which he renewed the next day, that the fleet would remain French or perish.

Still Roosevelt continued to worry about the fleet. Pétain's meeting with Hitler at Montoire raised questions about how trustworthy the Vichy government was. After that meeting Roosevelt sent a strong statement to pétain saying that he saw no justification for France to help Germany against Britain, her former ally, and warned Pétain against permitting Germany to use the fleet. Any such agreement:

would permanently remove any chance that we would aid the French people in their distress and in these conditions we would make no effort to exercise our influence in insuring France the retention of her overseas possessions. (34)

Roosevelt, of course, was putting himself in a contradictory position in promising help in the return of the French 
colonies.

Besides the United States government's desire to keep the French fleet and colonies out of German hands, it had other reasons for continuing the Vichy policy. There were humanitarian reasons. The United states wanted the French people to know it was still their friend and give them hope of eventual Nazi defeat. Furthermore, the United States had an important listening post for obtaining word of what the Nazis might be doing. As Churchill was to describe it later, "the position of the Americans at vichy gave us a window on that courtyard that otherwise would not have existed." (35) Also the United States hoped to influence the Vichy government not to collaborate with the Germans. To carry out this task Roosevelt sought an ambassador to France in the fall of 1940 who could talk to Petain since Bullitt had returned to the united states after the armistice.

Roosevelt's first choice was General John Pershing, who had fought alongside Pétain in world war $I$. When Pershing could not accept the appointment because of ill health, Roosevelt asked Admiral William Leahy, former Chief of Naval Operations. Roosevelt thought that Leahy as a former Navy man could gain the respect of petain and have some influence with Admiral Darlan. In a letter to Leahy outlining American policy toward France, Roosevelt asked the new ambassador "to cultivate as close relations with Marshal pétain as may be possible." (36) Roosevelt feared that petain had been unaware of what Laval had been doing as 
vice-premier and that it might be the same with his replacement. Roosevelt asked Leahy to bring any acts not in the interest of the United states to pétain's attention. (37) At the same time Leahy was to keep petain informed of the support the United States was giving the British. Leahy was to remind the French naval officers that to allow Germany the use of the French fleet or naval bases would forfeit the friendship of the United States. (38) As for the children in unoccupied France, the United states would be favorable to sending medical supplies and milk if it were assured it would not assist Germany. (39) Finally, in view of the French effort to stay in authority in North Africa, Leahy was to offer assistance to help improve the economic situation there.

There were several reasons Roosevelt was interested in North Africa. The port of Dakar was the closest point in Africa to the western hemisphere and he did not want to see it in German hands. He had also heard that there was an army there which might be brought back into the fight against the Axis. Embassy reports from France about a trip the American naval attache had made to North Africa had come to his attention. The naval attache had found that the French military establishment in North Africa was far stronger than had been expected. Furthermore, these military men had not lost their fighting spirit. While they had accepted the German armistice and had sworn allegiance to Marshal pétain, they expected to defend the African empire in spite of the 
collapse of the mother country. The naval attache told the American diplomats in France, "If France is going to fight again anywhere in this war, I believe North Africa will be the place." (40)

After reading these reports about North Africa, Roosevelt summoned Robert Murphy, chargé d'affaires at Vichy, to the United States. Murphy had been a career foreign service officer since 1917 and had been counselor of the United States Embassy in Paris at the time of the armistice. In his hour long conversation with Murphy at the White House, Roosevelt expressed the belief that North Africa was the most likely place French troops might be brought back into the war against the Germans. Roosevelt asked Murphy to return to Vichy and work to obtain permission to make a thorough inspection tour of North Africa. According to Murphy,

The French African policy of the United States Government thus became the President's personal policy. He initiated it, he kept it going and he resisted pressures against it, until in the autumn of 1942 French North Africa became the first major battle ground where Americans fought Germans. (41)

One of the reasons Roosevelt thought there might well be anti-German action in North Africa was because Weygand had been made Delegate General there by the Vichy government. As a French world war I hero, Roosevelt could not believe weygand would indefinitely tolerate French subservience to Germany. Roosevelt thought that the fact that Murphy was a Roman Catholic would help in his dealings 
with Weygand. Roosevelt suggested to Murphy, "You might even go to church with Weygand." (42) As Murphy left the white House, Roosevelt told him to communicate anything of special interest about North Africa directly to him and not to bother with the state Department. Thus, Murphy became one of Roosevelt's "personal representatives". Roosevelt was known for establishing personal contacts like this which short-circuited the bureaucracy.

The United States realized that the best approach to Weygand would be economic. Upon his return to Vichy, Murphy obtained permission to tour French Africa in December of 1940. One of the first things he did was pay his respects to General Weygand at Dakar, where the latter was on an inspection tour. Murphy found that North Africa was in real economic distress. Because of the British blockade there was a shortage of gasoline, cotton fabrics, and food, including green tea liked by the North Africans. Weygand believed consumer goods were urgently needed as an incentive to North African cooperation in defense of the area and to make them less susceptible to German propaganda. For their part the Germans hoped that Morocco would have a nationalist revolution and that the North Africans would ask for German protection. (43)

The United States was receptive to sending supplies, but it was necessary to obtain permission from the British to go through the blockade. The British were reluctant to grant this fearing that supplies to North Africa would only 
help the Nazis. They particularly were concerned that goods might be transshipped to Germany. Ostensibly to placate the British, the Americans requested that American observers inspect all shipments. This was agreed to by the French. Thus the Murphy-Weygand Accord signed on February 26, 1941 permitted the use of Erench funds frozen in the United States to buy nonstrategic goods and ship them to North Africa. To see that nothing was transshiped to the Germans, twelve American control officers, serving as vice-consuls, were to supervise the distribution. While the job of these men, according to the Accord, was to supervise the shipments, everyone knew, even pétain and weygand, that these Americans really would be intelligence agents. (44) They could observe the activities of the Axis powers, could note conditions of the North Africans, look at the depth of port facilities, landing locations and roads, and make contacts. Weygand made another concession, demonstrating his confidence in the United States, which was to allow the vice-consuls to use secret codes and to employ couriers carrying locked pouches.

The War Department was asked to find twelve officers who would be reassigned to the state Department. Since army officers could be convicted, if caught, and tried as spies, it was decided that they should resign from the army before assuming their new posts. Mainly from the New York area, these vice-consuls were chosen on the basis of their knowledge of France and the French language. They started 
arriving in April 1941 and by December all twelve were at their posts. Murphy was assigned to North Africa as a sort of High Commissioner with the job of maintaining contacts, particularly with weygand. He was also to supervise the vice-consuls.

The vice-consuls would soon come under the new intelligence organization created by william Donovan, known since childhood as "wild Bill". Donovan had impressed upon Roosevelt the need to consolidate the Military and Naval Intelligence under a coordinator of Strategic Information who would be responsible directly to the President. This service, besides analyzing and interpreting material, was also to direct psychological warfare. (45) In July 1941 the Office of Coordinator of Information (COI - later changed to Office of Strategic Services, or OSS) was set up under Donovan. It was in charge of establishing a secret intelligence service as well as with the organization of special operations. One of the first tasks of the new COI was to station an assistant naval attaché in North Africa to unify the actvities of the vice-consuls and stimulate efforts in selection of "local agents of information." (46) The man picked for this job was Marine Colonel william Eddy and he was assigned as naval attaché to Tangier.

Overall relief to North Africa from the United States was never enough to help her ailing economy. Economic aid was an on-and-off affair, subjected to the American carrotand-stick policy toward Vichy. The United States threatened 
to stop aid several times when it suspected collaboration with Germany and in some cases actually did. In the spring of 1941 with Hitler marching into Yugoslavia and Greece, on the offensive in Libya (where the Germans had gone to help the Italians fight against the English), and threatening Syria and Lebanon, Darlan was ready to make concessions. Leahy reported to washington that the trend of French policy was toward greater collaboration. Even the people outside of the "small but influential collaborationist circle" anticipated a German victory. Many believed that the French, by helping the Germans now, could obtain more generous peace terms later. (47) As mentioned earlier, Darlan by the Paris Protocols of May had offered bases in Syria and North Africa, including facilities in Tunisia, to the Germans. Petain even announced closer collaboration with Hitler in a radio broadcast. (48) Leahy wrote that it was evident that the Marshal was "going the full distance in collaboration with Hitler." (49) Leahy thought that the only way to keep France from complete control by Germany was a "definite setback to the German program by application of superior force to some important point and before it was too late." (50) He wrote, "Today the vulnerable spot is North Africa." (51)

In response to Darlan's collaborationist policy, President Roosevelt said in a radio address he could hardly believe that the present government of France could be brought to lend itself to a plan of voluntary alliance implied or otherwise which would apparently deliver up 
France and its colonial Empire. (52)

In a letter to Leahy, Roosevelt wrote

the efforts of Admiral Darlan and others of

the Government to increase collaboration

with Germany has [sic] definitely compromised

our program of assistance to France. (53)

He added that flour shipments would stop unless there was

a "positive resistance to German demands." (54)

Because of Weygand's resistance, the Paris protocols were not put into effect. Weygand flew to Paris in June for a meeting in which he took a firm stand against any further collaboration. He insisted on the maintenance of the status quo in North Africa, resistance to any foreign penetration there, and no action against the de Gaulle forces in North Africa. He was backed in his position by Admiral Esteva, the Resident General of Tunisia, who had also flown to Paris for the meeting. Afterwards it was rumored in Tunisia, according to the American consul there, that Esteva might be replaced because he had backed Weygand. (55)

Darlan was now becoming impatient with Weygand. He felt Weygand was pushing North Africa, with American encouragement, toward increasing independence from Vichy. Darlan feared that Weygand's premature dealings with the United States would result in a German occupation of French North Africa. By November Darlan succeeded in having weygand recalled. German pressure may have played a part. The Germans were suspicious of Weygand's contacts with the Americans and they may have known about a remark weygand had made while having lunch with Petain and others at vichy of 
his wish to see the Germans beaten by the Russians. (56) Because of Weygand's recall, the United States seriously considered stopping its aid. Leahy considered the "jelly fish" reaction of the Pétain government justification for stopping all assistance to France as well as his own recall. Weygand urged that it be continued, however, telling Murphy that nothing had changed in French policy by his departure. (57) Weygand thought the aid program gave France the opportunity to have an economic and political relation with the United States, which he believed would be an arbiter at the end of the war. If Germany could penetrate French North Africa, it would be able to inflict its will upon France "without the possibility of a reaction." (58) Murphy too thought that cancellation of the accord would deprive the United states of advantages such as maintaining representatives in the area. Murphy tried to persuade the state Department there were many other Frenchmen in North Africa with whom he could work. Pétain assured Roosevelt that Weygand's departure had not changed French policy.

What saved the supply program was the Japanese attack on Pearl Harbor and the entry of the United states in the war. When Churchill came to washington at Christmas to discuss strategy with Roosevelt, the idea of attacking North Africa was seriously considered. At that time it was feared that Hitler might attempt to strike at North Africa through Spain or attempt to use Tunisia to supply General Erwin 
Rommel's troops, which were then on the defensive in Libya. An allied invasion would forestall this possibility as well as relieve the pressure on the British in Egypt. In fact Roosevelt and Churchill decided to approach weygand, now in retirement, to see if he would return to North Africa secretly to rally the French Army to the side of an AngloAmerican expeditionary force they hoped to send there. Out of loyalty to pétain, weygand refused.

As already pointed out, de Gaulle was not considered to take the leadership in North Africa against the Germans because of the anti-de Gaullist sentiment there. But there were other reasons as well. The Free French movement appeared to be in a state of confusion. While they had an informal representation in the United States, they were not joined by many prominent Frenchmen such as Mendes-France living in the United States and some of the French in America backed Pétain. According to william Donovan, the whole Free French movement was in a "deplorable condition" and he suggested that Roosevelt discuss with Churchill the idea of getting another leader out of France such as Edouard Herriot to take it over. (59) If on December 23, when Donovan wrote his memo, he questioned de Gaulle's leadership ability, events of December 24 would cause Roosevelt and Hull to distrust it from then on.

While Roosevelt and Churchill were celebratng Christmas eve, the Free French forces under Admiral Émile Musilier took over the French islands of St. Pierre and 
Miquelon off Newfoundland. St. Pierre was of concern because of its wireless transmitting station. Both Canada and the United states had been discussing what to do to keep it from enemy hands, when de Gaulle occupied it without consulting the American government. Muselier, who carried out de Gaulle's order, told the American consul on st. Pierre that de Gaulle's order was that of a dictator and he was sure that he had not even consulted the Free French at London. While Muselier would see the action through, he planned to resign on his return to London as a protest against the unilateral order given by de Gaulle. (50) From this time on Roosevelt and Hull worried about de Gaulle's dictatorial tendencies. At the time Hull feared de Gaulle's actions would jeopardize the whole Vichy policy "which we have been nursing for a considerable period." (61) Leahy cabled that Darlan was saying that the Germans would use it as an excuse to move troops into Africa to protect it from similar invasions. (62)

While Hull worried about the effects the st. Pierre and Miquelon incident would have on the Vichy policy, other Americans now questioned this policy. Hull in his fury referred to the "so called Free French." The press, of course, picked up this remark and raised questions about the Vichy policy. Because of Hull's intense antipathy toward de Gaulle, he lost support both from the American people and his own president. The public were now concerned about the State Department's ready acceptance of Vichy. (63) Roosevelt 
increasingly became his own secretary of state and eliminated Hull from important French matters. In North Africa he relied on Robert Murphy as his personal emissary. 
NOTES

CHAPTER II

1. Orville H. Bullitt, ed., For the President:

Personal and secret Correspondence Between Franklin D.

Roosevelt and William C. Bullitt (Boston: Houghton Mifflin Co., 1972), 457 .

2. Ibid, 450 .

3. Cordell Hull, The Memoirs of Cordell Hull $(2$ vols., New York: Macmilian, 1957-81, I, 765.

4. R. T. Thomas, Britain and Vichy: The Dilemma of Anglo-French Relations 1940-42 (New York: St. Martins Press, 1979), 7 .

5. Quoted in Andre Maurois, A History of France (trans. by Henry L. Binsse, New York: Farrar, Straus and Cudahy, 1956), 527 .

6. Pierre Laffont, Histoire de la France en Algérie (n.p.: Librairie Plon, 1980), 326. This and all subsequent translations are by the author unless otherwise noted.

7. Ibid, 326 .

8. Ibid, 327 .

9. Heisler to Hull, July 3, 1940, State Department Papers, deposited in the National Archives, Washington, D.C. Decimal File Number 851S.00/170. Hereafter cited by Decimal File Number.

10. Reynaud to Petain, April 5, 1941, President's Secretary's File, Safe File France, Roosevelt Library, Hyde Park, New York. Hereafter cited PSF.

11. The Banque Worms Summary, December 8, 1941, PSF Container 163, December 18-21, 1941.

12. Maxime Weygand, Recalled to Service (Garden City, New York: Doubleday, 1952) 231. 
13. Department of State, Foreign Relations of the United States, 1940 (7 vols., Washington, D.C., 1962), II, 378. Hereafter cited FRUS.

14. Ibid, 379 .

15. Ibid, 423 .

16. Leahy Diary 6, deposited in the Library of Congress, Washington, D.C., 18 .

17. FRUS 1940 II, 472 .

18. Ibid, 419 .

19. Leahy Diary 6, January 21, 1941, 7.

20. Robert 0 . Paxton, Vichy France: Old Guard and New Order, 1940-44 (New York: Norton, 1972), 112-113.

21. Ibid, 117 .

22. Bullitt, For the President, 452.

23. Ibid.

24. Charles de Gaulle, Mémoires de Guerre: L'Appel (Paris: Librairie Plon, 1954), 119.

25. Ibid, 119 .

26. Franklin D. Roosevelt, "Our Foreign Policy: A Democratic View", Foreign Affairs, 6 (July 1928), 584.

27. Leon Borden Blair, Western window in the Arab

World (Austin: University of Texas, 1971), 31-32.

28. Hul1, Memoirs, I, 278.

29. Ibid, 771 .

30. Weygand, Recalled to Service, 178.

31. Bullitt, For the President, 434.

32. FRUS 1940 II, 456.

33. Pierre Renouvin, Les Crises du XX Siecle 12 vols., of Histoire des Relations Internationales, Tome Hutieme, Paris: Hachette, 1957-58), II, 270.

34. Hull, Memoirs, I, 850 .

35. Winston S. Churchill, The Second World War: The 
Hinge of Fate (Boston: Houghton Mifflin 1950), 693-640.

36. FRUS 1940 II, 426.

37. Ibid.

38. Ibid, 428 .

39. Ibid.

40. Robert Murphy, Diplomat Among Warriors (Garden City, New York, Doubleday, 1964), 67.

41. Ibid, 68 .

42. Ibid.

43. Blair, western Window in the Arab World, 36 .

44. Murphy, Diplomat Among Warriors, 89.

45. PSF, Coordinator of Information, Nemo for the President, June 10, 1941.

46. Ibid, Box 141, October 10, 1941.

47. FRUS 1941 II, 168.

48. Ibid, Footnote no. 7, 172.

49. Leahy Diary 6, May 15, 1941, 57.

50. Ibid, May 22, 1941, 60-61.

51. Ibid.

52. Ibid, May 13, 1941, 58.

53. Letter Roosevelt to Leahy received May 23, 1941, Leahy Diary.

54. Ibid.

55. Doolittle to Hull, June 27, 1941, 8515.00/184.

56. Weygand, Recalled to Service, 341.

57. FRUS 1942 II, 472.

58. Murphy, Diplomat Among Warriors, 94.

59. PSF 163, No. 99.

60. FRUS 1941 II, 557. 
61. Ibid, 558.

62. Ibid, 503.

63. Dorothy Shipley White, Seeds of Discord: De Gaulle, Free France and the Allies (Syracuse: Syracuse University Press, 1964), 14 . 
CHAPTER II I

TUNISIAN BACKGROUND

Although plans for a North African invasion had been set aside in December 1941, the United States still had a keen interest in North Africa. Two vice-consuls destined for Tunisia would arrive by the spring of that year. They would discover a country that in the midst of centuries of foreign domination had known periods of independence. Though Tunisia had lost this independence when it became a French protectorate in 1881, it was not long before a nationalist movement aroused hopes for renewed autonomy. Since theoretically a protectorate was an independent regency under French protection rather than a colony, the nationalists were complaining that the French had made Tunisia a colony under the guise of a protectorate. After the French debacle of 1940, a new Bey, who came to power in 1942 and identified with the nationalists, had dared to ask the French for Tunisian autonomy as laid out in the original Treaty of Bardo. While the Erench were desperately clinging to what remnants they had left of their own past glory, the Bey was attempting to capitalize on French weakness to recapture an independence his country had known in better times. 
times.

The Tunisian nationalists could look back on a rich and interesting history. Tunisia, originally inhabited by Berbers, knew many invaders starting with the Phoenicians, who settled along the coast and founded the important trading city of Carthage. The Romans followed the Phoenicians and made Tunisia a province in 146 B.C. Tunisia, rich in wheat, olive oil, and minerals, was a prosperous part of the Empire. Carthage became the second city of the Latin part of the Empire and with men such as Augustine played an important part in the history of Latin Christianity. From Roman times, Tunisia has existed as a self-conscious cultural unit and has differentiated itself from the surrounding regions.

With the Arab invasions of the seventh century the Latin language and Christian faith disappeared. The Berbers of the mountains, who had never really been Christianized or Latinized, accepted the Moslems. Following the Moslem conquest, Tunisia was dominated at different times by Norman, Moroccan, Spanish, and Turkish rulers. The Turks arrived in 1525 and ruled in the name of the Ottoman Empire, but were too weak to maintain real control after 1600. By 1705 Tunisia was virtually independent under hereditary regents from whom the Beys of the world war II period were descended. (1)

Under the early Beys Tunis had a reputation for turning its head when pirate ships came into the harbor. 
Though the European powers occasionally managed to check piracy by treaty, piracy continued until the nineteenth century and provided public revenue for Tunis. During that century, the Tunisian people won reforms from the Bey and in 1861 he gave them a Constitution, though by 1864 it was suspended.

In the scramble for colonies by the European powers in the nineteenth century, both the Italians and French wanted Tunisia. There were actually more Italian settlers there than French, but at the Congress of Berlin in 1878 Great Britain and Germany agreed to concede Tunisia to France. Great Britain had been willing to give France a "free hand" in Tunisia in exchange for French acquiescence to British annexation of Cyprus. Germany under Chancellor otto von Bismarck saw in France's interest in Tunisia a way of taking its recently defeated neighbor's mind off revenge. The British Ambassador in Berlin expressed the Chancellor's attitude:

He is in great spirits since the French have gone into the Tunis trap, which he baited for them during the congress, and chuckles over the security Germany will enjoy from a diminished Army in France with increased occupation in Africa . (2)

Under the pretext of punishing some native tribes in 1881, a French force crossed the Algerian frontier, advanced toward the capital, Tunis, and forced the Bey to accept the French protectorate. The Treaty of Bardo was signed May 12, 1881. While this treaty maintained the nominal sovereignty 
of the Bey, the Treaty of Marsa of 1883 did away with any real Tunisian independence. French rule steadily encroached on native power.

The Italians felt Bismarck had slighted them by awarding Tunisia to the French. Nevertheless, they retained the special privileges the Bey had granted them in the form of capitulatory rights in 1868. They could hold Italian citizenship, maintain their own schools and practice all professions without the benefit of a French diploma. (3)

Under the protectorate Tunisia was administered by a French and a Tunisian section. The French section was headed by a Resident General who exercised supreme control over the Protectorate's administrative services. He served as Foreign Minister and as president of a Council of Ministers which included three Tunisians. The Resident General was assisted by a French delegate, a French military cabinet and a French civil cabinet. For administrative purposes Tunisia was divided into five regions, each of which was further subdivided into nineteen controles civils, each administered by a French controleur. (4)

The Tunisian section of the government was headed by the Bey. Assisting him were three native ministers: a Prime Minister aided by a French Director General of the Interior; a Minister of Justice aided by a French Director of Tunisian Justice, and a Minister of the Pen. Administratively Tunisia was divided into thirty six caidats under native caids who held administrative, judicial and financial powers. Each 
caidat was subdivided into shaykhates, 604 in all, each under the authority of a shaikh. The Grand Council which voted the budget consisted of both a French and Tunisian section. (5)

Authority ultimately lay with the French; the Bey had become in effect a puppet. All decrees of the Bey had to be promulgated by the Resident General who also prepared the Beylical decrees. As French historian Charles-André Julien put it:

In Tunisia, however, the higher French officials have gradually substituted their own authority for that of the Tunisian ministers while the controleurs civils have absorbed the power of the caids and the French gendarmerie has replaced the native spahis. (6)

In spite of the fact that the Bey had become a French puppet, Tunisian allegiance was to the Bey.

Until 1912 Tunisia was the quietest country in North Africa. The Moslem leaders of the religious community, known as the old Turbans, followed a policy of cooperation with the French. This changed in 1912 when Abd el-Aziz Tha'alibi founded the Young Tunisians. Modeled after the Young Turks and influenced by western liberalism, they called for an extension of rights and liberties equal to those of Europeans. They were opposed by the old Turbans until 1919 when the French wanted to use some habous (religious) land for colonization. The old Turbans opposed this and reconciled themselves with the Young Tunisians. (7)

In 1919 a delegation of Young Tunisians and old Turbans presented their claims at the Paris Peace 
Conference. Their hopes had been raised by Woodrow wilson's ideas of self-determination for all peoples. They were bitterly disappointed when they met an unyielding attitude on the part of Georges Clemenceau.

Under Shaikh Tha'alabi the Destour (meaning constitution) Party was founded in 1920 calling for a constitution under which the Bey and his dynasty would retain leadership of the country. By 1922 tension between Naceur Bey, who supported the Destour program, and the French came to a head when the Bey threatened to resign unless the Destour demands were met by the French. While the French granted some reforms, the Destour were not satisfied. With the failure of the French to meet their demands Shaikh Tha'alibi went into exile. The French then began repressive measures. The discouraged Destourians calmed down their activities and waited for a more favorable climate, which came in the thirties.

Led by Habib Bourguiba, a lawyer, and Mahmoud Materi, a doctor, a group of young nationalists broke away from the Destour and began a new party, the Neo-Destour, in 1934 which was more militant and had broader appeal. Bourguiba insisted that only continual pressure would make France give up Tunisia. Whereas the older Destour was aristocratic and upper middle class in its outlook, the Neo-Destour was a liberal constitutionalist group whose leadership thought it important to integrate the masses into the party. The Neo-Destour were successful in winning public support. The 
French responded to increased Neo-Destourian activity by sending Bourguiba and Materi into exile in the Sahara in 1934. (10)

When the Popular Front came to power in 1936, it was more tolerant of nationalist aspirations and Bourguiba and Materi were allowed to return. By 1937 the Neo-Destour had gained ascendancy over the Destour and Bourguiba took the opportunity to organize a campaign which sought to obtain Tunisian independence through negotiation and persuasion while also maintaining friendly relations with France. Premier Leon Blum's promise of independence to Syria had raised the hopes of the Tunisians. When the popular Front fell, the French policy stiffened causing Bourguiba to begin a campaign of civil disobedience. Demonstrations and riots followed. On April 29, 1938 the French killed 122 demonstrators. Both the Destour and the Neo-Destour were banned while Bourguiba was arrested and sent to prison in Marseille. (11)

Though the Neo-Destour's leader was in prison, it, along with the Destour, continued to be the focus for nationalist ambitions. The success of the Neo-Destour in winning mass support has been attributed in part to the homogeneity of the Tunisian society. According to Carl Leon Brown, as far back as pre-protectorate days

- . Tunisia was blessed with a relatively homogenous population with a long tradition of living together and of considering itself a single society. There was one national language, Arabic lonly a few thousand Berber- 
speaking irhabitants remained at this time), and except for a fairly well integrated Jewish community, a single national religion, Islam. Furthermore, Tunisian Moslems . . were not split into opposing sects; nearly all Tunisian Moslems belonged to the orthodox Sunni community. (12)

At the time of World War II ninety percent of the population was Moslem out of a total population of just under 2,500,000. While the Moslems were predominantly Berber mixed with Arab, only one percent spoke Berber. There were 60,000 Jews, mainly Tunisian, but with a few European refugees. The Jewish community had long been a part of Tunisian society. Though religiously separated, they were quite close to the Moslem majority, playing an important role in the economic life of the country. Of the Europeans there were about 108,000 French, roughly the same number of Italians, and a smattering of Maltese, Greeks, and Spaniards. (13)

The make up of the population played an important role in political and economic affairs. The economic structure tended to divide along ethnic lines. Agriculture was the principal means of subsistence and most of the Moslems were involved in agriculture either as workers or as the owners of the largest percentage of the approximately $19,000,000$ olive trees in Tunisia. While Moslems owned some vineyards, they were primarily in the hands of the French and Italians. In general the Europeans were the owners of the large, modernized farms. In the northern region the French owned over ninety percent of the European-owned Iand. 
In contrast to the French immigrants who went to Algeria and were roughly a cross section of the French population, those who went to Tunisia were a more favored group, partly because French immigrants in the nineteenth century were required to buy some land. Frenchmen were also merchants and held most of the goverment posts. The Italians, who came mainly from sicily and Sardinia, worked as miners, masons, agricultural workers, and artisans. While they were also the owners of small vineyards, generally they were quite poor. Tunisian Jews were primarily in merchandising and in skilled labor with a small percentage in the professions.

Except for the mining of phosphates, there was very little industry. It was said that the French discouraged native industry to avoid competition with the mother country. On the whole the economy was developed by and for the French. Where the traditional peasant agriculture had been self-sufficient, the colonial economy was oriented toward producing raw materials for the French and consuming the products of French industry. The Tunisians played a subservient role in the development. "Tunisians were like guests in their own houses." (14)

Despite the homogenous population, there were some underlying tensions between the different groups, which were exacerbated by the war. The French, as the colonizers, were disliked by the Tunisians. The Tunisians resented the Italians too because as manual workers they tended to take 
jobs from them. As for the Jews there was some anti-Jewish bias which, according to Carl Brown, may have stemmed partly from the fact that the Jews tended to assimilate the French language and culture faster than the Tunisians and even desired to become part of the French community instead of being under beylical authority. (15)

with the outbreak of the war, the French were in a more vulnerable position. The Tunisians, seeing that the French had been beaten, had hope for their own independence. But bad as the French were, the Tunisians preferred them to the Italians, whom they knew had designs on Tunisia. They also knew that the Italians treated the Libyans poorly. The kind of racial discrimation against the Jews introduced by the Vichy government during the war was quite alien to the Tunisians and was violently objected to by the Bey. In fact carrying out the policy was a job that even the French Resident General disliked and one that caused him difficulties with the Tunisians.

Under the Vichy regime the French administration in Tunisia became more authoritarian. Masonic lodges were forbidden while the press, radio, and publc meetings were prohibited for the Tunisians. Official discrimination against the Jews in Tunisia started with the Vichy anti-Jewish statue of November 30 , 1940, which excluded them from the teaching professions, all liberal professions, and from the publishing and film industries. Sequestration of Jewish property was authorized and registration of all Jews 
was required. They were forbidden to own any property except that in which they lived and were prohibited from collecting debts. Jewish doctors and lawyers were limited in their practice. (16)

The man who was responsible for enforcing these new laws was Admiral Jean Pierre Esteva, who had been appointed Resident General because of his naval connections with Admiral Darlan, ana had arrived in Tunis in July 1940. Soon after his arrival Esteva made a radio address in which he pointed out his wish for a "rebirth of the concept of family." (17) Besides promoting Pétain's ideas, he replaced a great many bureaucrats, but not all because, as he wrote Darlan, recruiting locally was difficult. (18)

As for the Jews, Esteva appeared to want to convince Vichy that he was doing his best to follow its orders while at the same time going slowly in carrying out those orders so as not to upset the Tunisian population. Esteva convoked the Jewish community and informed them that he wanted to end abuses such as "usury, unwholesome speculation and hoarding". (19) starting in 1940 a certain number of Jews had their merchandise confiscated and sold for the profit of the state. Esteva also fined them substantially. Writing to reassure Darlan, Esteva reported that his repression against the Jews had not ceased, but that it was important to recognize that since time immemorial Tunisia had lived thanks only to the Jews. During World war I supplies had been assured only because of their 
intervention. Since the non-Jews were not always honest or capable, Esteva had had to tolerate Jewish trading. Esteva feared that, if he suppressed all the Jews, other individuals would replace them who would be without scruples and "who would skin their contemporaries." Further

we musn't forget that when the Moslems are on good terms with the Jews which often happens, the Moslems don't hesitate to tell the Jews that the persecution comes from us and from the Germans and that for them they desire to live in harmony with their Jewish brothers. (20)

Esteva recommended that the French act with firmness toward the Jews, but not fall into systematic and blind persecution. (21)

It was into this situation of overt harmony and latent antagonisms that Hooker Doolittle came when he arrived in Tunis in the spring of 1941 as the American Consul General. Doolittle, a native of New York state and a graduate of Cornell University, had gone into the foreign service after a brief stint in business. His first post was in Tiflis in Russian Georgia. There he met his wife, Victoria, the daughter of a Russian army officer. Before his assignment in Tunisia, Doolittle had served in Morocco and knew both Arabic and French.

The vice-consuls, John Utter and Harry Woodruff, also arrived in the spring of 1941. They were responsible for verifying the employment of the merchandise received from America, assuring that it was used in the Regency and not sent to France or Tripolitania. According to Esteva, they 
were often seen at the ports or talking with a certain number of bureaucrats or circulating in the country. On their observation trips into the Tunisian countryside, they found that the natives were desperately poor. There was a serious shortage of both food and clothing. Doolittle, who sometimes accompanied the vice-consuls, wrote that "most Arabs did not ever get a really good meal" and because of the lack of cloth, they were "miserably clad." (22) In the area that Doolittle visited, the Tunisians had gone to the office of the caid to obtain releases for purchases of small consignments of American cotton goods which had just been received.

Esteva himself was keenly aware of the need for clothing. Tunisian authorities as well as the colons were coming to him to tell him that the women and children in the country lacked clothes and were practically nude. On his own trips into the countryside, he had seen men and children dressed in rags while the women hid refusing, out of modesty, to go out except at night. In writing Darlan, he said they needed millions of tons of cotton goods and not the two or three hundred tons that arrived from America or France. (23)

Doolittle and the vice-consuls noted the Tunisian contempt for the Italians. They found that it was due partly to the fact that Italian workers who migrated to Tunisia were hard working and desperately poor. While French immigrants tended to create enterprises which employed 
natives, Italians displaced native labor by doing the same work and doing it more effectively.

Doolittle and the vice-consuls also noted the Tunisian dislike of the French. As woodruff wrote, "They are the conquerors and as such have incurred a constant underlying hostility." (24) Doolittle found that "the mainspring of Arab psychology is their anti-French feeling." (25) Throughout the Protectorate the Tunisians stressed to the consul and vice-consuls the need for independence or greater self-government. The Tunisians resented not being able to develop their own industries because of pressure from French manufactures. They also resented not having positions in the administration as well as the fact that the French bureaucrats were "mostly mediocre" and often "enriched themselves while in service." (26) While the French were aware of the discontent and had attempted to placate the Tunisians in minor ways,

Doolittle found

they fail to get to the crux of the matter which is the complete subservience of the Arab population to their French masters and the resolute exclusion of all Arabs from any economic and political life of the country. (27)

Further

The so-called Tunisian or Beylical Government with its 'Possessor of the Kingdom', Ministers, Caids, and Cadis [Islamic Judge], each of which has a French controller at his side to divide the profits derived from spoliation of the 'fellah' is a complete mockery and is only permitted to exist as window-dressing and such weight it may have in deluding the masses of the people. That this delusion fails to delude is apparent from the contemptuous manner in which 
nearly all Arabs, high and low, refer to their

'Sovereign Prince' and his satellites. (28)

Considering the Tunisian discontent with the French, it was not surprising that German war propaganda was having its effect on them. Because the Germans had conquered the French, the Tunisians were receptive to what they said. Radio Ankara also influenced the Tunisians. When Radio Ankara was pro-German, the Tunisians felt that way and when Ankara swung toward Britain they followed. Doolittle thought the British radio might counteract this German propaganda by letting it be known that Britain intended, if such intentions existed, to help the Tunisian people obtain their independence. Doolittle realized this might be political dynamite but believed it was a question which needed to be confronted some time or other. Of course, the British had no such intention. Not only would the British evade this question, but, as it would turn out, so would Doolittle's own government.

At that time Doolittle and the consuls found American prestige high among the French and Tunisians. Both groups wanted more information about American aid. Because of Axis jamming of foreign radio stations, they were not getting the facts about aid. Vice-Consul utter thought that the Tunisian population should know what the united States was doing and that it was solicitous of their welfare. The consul and vice-consuls emphasized the value of American representation. Of all the powers the united States enjoyed the greatest prestige in the Near East because the Tunisians 
believed the United States had no political aspirations and was the only disinterested power to which they could turn. Doolittle thought the implications of this position were so great that serious consideration should be given to developing American connections in the Middle East. (29)

In an effort to develop connections with the French army officers, Doolittle and the vice-consuls had invited many of them and their families to consular functions. Disturbed by this, Esteva wrote to both Weygand and Darlan asking that officers be forbidden from accepting these invitations. Esteva thought this was necessary "to remedy the inconveniences which could result from French officers having contact with members of the American consular corps." (30) Since the United States had not entered the war at this point, Esteva must have feared that the Americans might undermine vichy authority.

Though Doolittle was not especially impressed with the nationalists when he first arrived, he gradually came to have many contacts with them. As time went by he became an advocate of their cause. His despatches tended to refer often to the Tunisians and nationalists and less frequently to the French. When he did mention the latter, it was often disparagingly.

If Esteva and the French administration did not want French officers to have contacts with Americans, they wanted even less for Tunisians to have contacts with them. For this reason Doolittle did as thorough an investigation of 
the strength of the Neo-Destour as possible "without arousing too much interest in French administrative circles." (31) He found that there was little cohesion among party members except for the general anti-French resentment. Because Bourguiba and the principal leaders of the party were still in prison in Marseille, the head of this movement was "apparently effectively lopped off." (32) Bourguiba's lieutenants who were still free were finding it hard to agree among themselves. Nevertheless, the party still had many adherents organized into what the French settlers referred to as "cells". The Neo-Destour put pressure on the Tunisians to join the party. Various methods were used such as refusing to marry or bury them until the proposed member signed on the dotted line. (33)

Doolittle learned that the Neo-Destour had split from the Destour because of the latter's growing conservatism. The Neo-Destour was composed primarily of younger men without much previous standing or wealth. They "wish to sweep away all the old fogies now blocking their route to power and glory." (34) Doolittle thought "they would cooperate gladly with any power other than the Italians who wanted to take a crack at their French masters." (35) Some of the party members had expressed the wish for American assistance and guidance, but judging by the past history of the country, Doolittle thought the Tunisians would tire "of even the most disinterested assistance which tried to instill a really efficient and honest administration." (36) 
Doolittle's assessment of the Neo-Destour was that they "represented no political value," were "a source of trouble," and had little future as a "democratic parliamentarian movement."(37) Doolittle's assessment would prove to be quite wrong for the Neo-Destour would be the party that in the future led the country to independence. The old Tunisian families, who tended to belong to the Destour, feared the loss of their privileges with the rise of the Neo-Destour. For these families, who before the French protectorate were similar to a feudal aristocracy, furnished the protectorate with most of the high Tunisian dignitaries, including caids and shaiks, allowed to exercise administrative functions.

The leader of the Destour, Shaikh Tha'alibi, requested an interview with Doolittle in October 1941. Doolittle, who went to his home, described Tha'albi as a "magnificent ruin of a man about sixty years of age." (38) The Shaikh told Doolittle that the Tunisians were now convinced that a British victory was inevitable in the war. They had concluded this because of the German invasion of Russia among other things. Originally they had believed that Germany would definitely win, but the Russian campaign which seemed to be going nowhere fast, as well as the visibly growing strength of the British as relayed by Tunisian sources in the Near East, had caused a great change in thinking. Doolittle found it significant that this was an "apparent change of heart away from the pro-German attitude 
reported by all observers in May and June to the pro-British sympathy now manifested." (39)

The Shaikh's purpose in wanting to see Doolittle was to put before the governments of the united states and Britain the plight of the Tunisians and learn how they could help in hastening the British victory as well as to find out what support the Tunisians could expect at the peace settlement in their goal of independence or at least more autonomy in administering their own country. (40)

The Shaikh said they had been approached by the de Gaulle forces, but had refused to see them as this would mean exchanging one group of Frenchmen for another. The Destour would prefer first an American protectorate and secondly a British and finally continuation of French rule if it could be drastically modified in its purpose and manner. Since this resembled too closely a conspiracy, Doolittle indicated this was out of the question. Besides, the United states had no political ambitions in foreign countries. Nor would he or the American government consider steps against the French. Doolittle suggested that the Tunisians settle their differences with the French and at the same time educate their young men to take their place in a modern world they hoped to occupy. The Shaikh said they had tried to come to an agreement with the French for a greater share of the administration of the country and in return the leaders had been exiled. Furthermore, there was no chance of their young men being given facilities for 
obtaining an education. (41)

World War II set in motion with renewed vigor the longings for independence in Tunisia as well as many other countries under colonial domination. It was a force that the French tried desperately to stem. The predicament for the Americans was how to keep the friendship of the French without turning their backs on legitimate Tunisian aspirations. The predicament soon caused serious differences among the American diplomats. 
NOTES

CHAPTER III

1. Nevill Barbour, "Variations of Arab National

Feeling in French North Africa," The Middle East Journal, 8, $1954,313-314$.

2. Paul Knaplund, Letters from the Berlin Embassy 1871-1874 (3 vols., of the Annual Report of the American Historical Association 1942, Washington D.C.: Government Printing Office, 1944), II, 220 .

3. Malige to Hull, January 2, 1945, 8515.00/1-245.

4. Research and Analysis 1469, 3-4. Organization of Strategic Services report deposited in the National Archives, Washington, D. C. Hereafter cited R\&A.

5. Ibid, 4 .

6. Charles-Andre' Julien, "France and Islam," Foreign Affairs, 18, (July 1940), 688 .

7. $R \& A 1593,8-9$.

8. Ibid, 9 .

9. Ibia, 11 .

10. Paul E. A. Romeril, "Tunisian Nationalisim: A Bibliographical Outline," The Middle East Journal, 14, 1960, 208 .

11. R\&A 1693, 16 .

12. C. A. Micaud, L. C. Brown, and C. H. Moore, Tunisia: The Poliltics of Modernization (New York: F.A. Praeger, 1964), 8-9.

13. R\&A 1469, 2 .

14. Dwight L. Ling, Tunisia from Protectorate to Republic (Bloomington: Indiana University Press, 1967), 77. 
15. Micaud, Brown and Moore, Tunisia, 27.

16. R\&A 7 .

17. Heisler to Hul1, August $3,1940,851500 / 172$.

18. Letter Esteva to Darlan, October 7, 1941, P-1-12, deposited in the Archives du Ministere des Affaires Etrangeres, 37 quai d'Orsay, Paris. Hereafter cited Quai d'orsay.

19. Ibid.

20. Ibid.

21. Ibia.

22. Doolittle to Hul1, November 17, 1941, 851.00/193. d'orsay.

23. Esteva to Darlan, October 2, 1941, P-4-1, Quai

24. Doolittle to Hull, October 1, 1941, $851.00 / 191$.

25. Doolittle to Hull, October $28,1941,851.00 / 192$.

26. Doolittle to Hull, August 20, 1941, 851S.00/186.

27. Ibid.

28. Doolittle to Hull, October 8, 1941, 8515.00/189.

29. Doolittle to Hull, October 28, 1941, 851.00/192. d'orsay.

30. Esteva to Darlan, October 3, 1941, P-4-4, Quai

31. Doolittle to Hul1, August 20, 1941, 8515.00/186.

32. Ibia.

33. Ibid.

34. Ibid.

35. Ibid.

36. Ibid.

37. Ibid.

38. Doolittle to Hull, October 8, 1941, 851s.00/189. 39. Ibid. 
-ptqI •tt

- ptraI • Of 
PALACE REVOLUTION

With the United States officially in the war, Doolittle took a more active role in assisting the war effort and counteracting the Germans. Whereas he had been primarily an observer of the Tunisian nationalists in 1941 , he now saw them as potentially useful allies and was more receptive to their proposals. His ideas of working with the Tunisians were forwarded from the state Department to Donovan, who looked upon them favorably, but they brought Doolittle into head-on conflict with Robert Murphy. Differences about working with the Tunisians existed not only between Murphy and Doolittle, but between the state Department and the Coordinator of Information (later OSS). The COI was interested in working with the North Africans while the state Department was afraid of upsetting the French.

In the winter of 1942 Darlan's policy of collaboration was particularly noticeable in Tunisia. In December 1941 Darlan had concluded an agreement with the Axis powers at Turin to ship five hundred tons a day of Axis material on French ships from Marseille to Tunis and across Tunisia to General Erwin Rommel's forces in Libya. In 
exchange the Italians had promised to urge the Germans to release French prisoners and to move the line separating occupied and unoccupied France northward. (1) Leahy, who had learned about this from an informer, questioned Darlan about the shipments. Darlan admitted that he had agreed to permit two hundred tons of supplies each week and a total of five hundred Italian motor trucks to be shipped in French vessels to Tunis in order to keep the Germans from seizing Bizerte. (2) Vice-Consuls Utter and Woodruff on trips out of Tunis reported that used Italian trucks were going from Tunis to Gabes to be forwarded to Libya. Gasoline from Algeria was also being sent to Libya where it was transferred to German and Italian tank trucks. (3) Moreover, the Resident General was requisitioning supplies from the local Tunisians to be sent to Libya.

While the Americans were upset about these supplies to Libya, Esteva in his despatches showed his disquiet at the Americans' knowleage of them. He wrote Darlan that everyone had seen trucks of a "particular color" carrying gasoline from Algeria and Northwest Tunisia toward Gabes. There were numerous trucks and a great deal of unaccustomed movement. The witnesses of these transports were making comments which were being spread around and which nobody had the power to stop. (4) Furthermore, Esteva told Darlan that sending supplies to Libya was causing serious discontent among the Tunisians.

In Washington Assistant secretary of state, sumner 
Welles, protested to the French Ambassador that this was the most serious situation which had arisen between the two governments and if not checked, a friendly united states policy toward Vichy would not continue. (6) Roosevelt threatened to recall Leahy for counsel unless assurances were given that no military aid would go to the Axis and that French ships would not be sent to aid in Axis acts of aggression. When the assurances requested were not forthcoming, Leahy thought he should be called home and he was instructed to that effect, but then Roosevelt decided that he should stay writing:

Not only is our presence in France and North Africa the last bridgehead to Europe but it likewise helps to hold the Iberian Peninsula in line. (7)

The United States, however, stopped aid to French North Africa until March when Darlan finally assured Roosevelt that he had stopped shipments with the exception of food supplies and trucks which would shortly be delivered. For his part, Esteva, calling on Robert Murphy on his way to Vichy, reassured him that the supplies going to Libya via Tunisia were not important and urged friendly cooperation between France and the United States. (8)

By this time colonel william Eddy, the recently appointed representative of the coordinator of Information (C.O.I.), was in Tangier under the cover of naval attaché. Born in Syria of missionary parents, he had served as head of the English Department of Cairo University and spoke 
Arabic fluently. Eddy worked with the C.O.I. recruits as well as with Murphy, Doolittle, and the vice-consuls, some of whom were also C.O.I. staff members.

In French North Africa Eddy was to make French and North African contacts who could gather intelligence if United States representatives should have to leave the area. He was also to supply resistance groups which would operate by sabotage as well as by organized armed resistance. Eddy found that there was already a well organized resistance group in Algeria, a smaller one in Morocco, and various sabotage and guerrilla groups in Tunisia, though no organized military resistance.

In talking with the Tunisian leaders, Doolittle was pursuing the kind of activity that was being done in Morocco by the C.O.I. representatives, Gordon Browne and Carleton coon. These two had spent time among the Riffians, Berbers living in the Rif mountains of northern Morocco. When coon, an anthropology professor at Harvard, was recruited by the C.O.I. in November 1941, his interviewers told him that the Germans planned to arive through spain from Vichy France and then to conquer Morocco, reinforcing Rommel and taking over the whole Midale East. A "rejuvenated Riffian army", recovering from the humiliation of their lost independence in 1926, might check this advance. Coon's diplomatic cover was as assistant to the American consul in Tangier, J. Rives Childs. He and Browne, another C.O.I. man, who had been appointed vice-consul, worked with the Riffian 
leaders to set up a resistance. C.O.I. agents worked in North Africa independently of the State Department even though they often had diplomatic cover as assistants or vice-consuls. Most of the time the Consular Corps did not know what the C.O.I. was doing.

Doolittle, who had been asked by Shaikh Tha'alibi in October 1941 about setting up an autonomous state under American or British protection, was approached again by Tunisian leaders. With the United States now in the war they must have considered it a favorable time to discuss the idea of driving out the French. If their services were of interest and if they were given arms, they would fight against the Axis. They would also encourage pro-United Nations sentiment among the Tunisians. In exchange they wanted a guarantee of independence and gave Doolittle a copy of a plan of the kind of government they hoped for. Should the United States accept their offer, he thought their organization could provide some twenty-five thousand men. (851S.00/199)

Though Doolittle reported that these conversations with the Tunisians had "reached an interesting stage," they were already beginning to back away. Their interest in helping the United Nations depended on how the British forces were doing in Libya. British losses in January of 1942 and British irability to hold Rommel's army were causing the Tunisians to lose esteem for the British and to withdraw from "the basis of understanding" Doolittle was 
reaching with them. (11)

As for as the French, Doolittle found their policy a mystery. Although they privately expressed pro-United Nations sentiments, every public act was positively pro-Axis. He had concluded that no help could be expected from the French. While support for the Tunisian cause would mean breaking with the French, the sympathy it would generate for the United States in the Islamic world would be great. (12)

In February Doolittle went to Tangier to discuss with Eddy ways of stopping the Axis shipments to Libya. On his return he wrote Eddy that the protests and publicity by British and American radio must have had their effect as he had learned that Vichy had stopped the shipments destined for Libya by way of Tunisia. He had also learned that five ships due to arrive had been cancelled. According to a friend in the local French government, Vichy had ordered this traffic stopped.

Doolittle suggested enlisting the cooperation of the Tunisians to stop shipments to Libya of goods originating in Tunisia. He proposed a scheme to bribe members of the Bey's family so they would depose the Bey's pro-French Prime Minister and replace him with a pro-American and pro-British one. (13)

To understand how this would work, Doolittle described to Eddy the political set up. The Bey had a French Resident General as his counselor and Minister of Foreign Affairs. 
Laws and decrees were prepared by the Resident General and presented to the Bey for his signature before they were put into effect. Usually these laws were given to the Bey on Thursday and promulgated the next day. This allowed no time for the Bey to consider. Technically the Bey's Prime Minister should have the time to counsel him about which bills to sign.

Doolittle proposed bribing members of the Bey's family to influence him to change Prime Ministers. Doolittle believed that the new Prime Minister could advise the Bey to wait a week before signing the laws and decress. During that week Doolittle then expected the Bey's family to convince him to withhold his signature from decrees harmful to the United Nations. In particular, this method could be used to stop a great deal of the supplies going to Libya "as it would be impossible to gouge them out of the local Tunisian producers without the Bey's assent." (14)

While Eddy received approval from Donovan and wrote Doolittle that $\$ 25,000$ had been made available for the "palace revolution," Murphy and the state Department lost no time in squelching it. Murphy wrote Doolittle that he didn't believe he had authorization from the American government for pursuing these talks with the Tunisians. Furthermore, he thought the French knew about them and, if he continued them, might ask for his recall. (15)

In writing to wallace Murray, Chief of the Division of Near Eastern Affairs, about this scheme as well as about 
Doolittle's earlier letter recounting his talk with Tunisian leaders, Murphy noted that Doolittle had "become sold on the notion that it is possible to build up in North Africa an Arab movement, antagonistic to the French, which could be useful to the Allied cause." (16)

As Murphy understood it, United States policy was to be mainly concerned with winning over the French military and civilians so that they might possibly resume hostilities against the Axis in North Africa. He was convinced that working with the Tunisians with the idea of eliminating the French from the area would incur French hostility. Murphy believed that if French elements could be persuaded to resume hostilities with American support "the Arabs would then be faced with a powerful fait accompli" (17) with the possiblity that the Americans could then take advantage of whatever help they would be willing to give provided the United States took care of their economic needs. Murphy said: "However, I do not pose in any degree as being well informed on the Arab question." (18)

Paul Alling of the Division of Near Eastern Affairs agreed with Murphy and wrote Doolittle "that the Department would consider any attempt to turn the Arab population against the French as dangerous in the highest degree." United States policy in North Africa was based upon building up the confidence of the French, particularly the military. Though the sentiments of the Tunisians were of some concern, the position of the French was what mattered to the state 
Department. While an Arab organization would be useful to the United States if its main purpose were to oppose the Axis, the Department was strongly opposed to any support of any movement that would sponsor a revolution against the French Protectorate. Alling wrote a memorandum on April 7 to Assistant Secretary of State Adolf Berle and Under-Secretary of State Sumner Welles explaining that the same problem had come up in Tangier and the charge d'affaires there, J. Rives Childs, had concluded that the very existence of the United States consular service in North Africa would be in jeopardy if the French thought American officers were encouraging the North Africans to seek redress of their grievances. (20) Childs, of course, was worried about the kind of activity Coon and Browne were involved in with the natives.

A confusing situation was already emerging. On the one hand Eddy's C.O.I. was actively working with the natives, while Murphy and the State Department were opposing it. To add to the confusion, Childs did not know what the real nature of Coon's work was. (21) In fact, according to Coon, whose brother was married to Doolittle's daughter, Katya, Doolittle was not in on what the C.O.I. was doing either. (22)

Doolittle replied to Alling that he agreed that the French were more important "to us than the disorganized Arab mass." (23) As far as the "palace revolution", it was only that and not an attempt to turn the Tunisian population against the French. Besides the Tunisians had already turned 
against the French. Doolittle had "yet to meet more than one or two who have the slightest kind word for the French colonial administration." (24) Nevertheless, he had counselled the Tunisians not to attempt any violent measures as these would gain them no sympathy from the Americans or the British. The "palace revolution" was proposed at a time when French supplies were going to Libya and the idea was to replace the present Prime Minister by one more sympathetic to the United Nations cause so he could influence the Bey to oppose "stripping his subjects for the benefit of the Italians." (25) In the meantime shipments had practically stopped, and, as Doolittle wrote Murphy, the "palace revolution" was beginning to happen of its own accord. (26) The Bey had been upset when thirty-five Destourians, who had been in prison locally since 1938 (the same time Bourguiba was sent to France to prison), were given harsh sentences. He asked his Prime Minister to intercede and, when the latter failed to do so, the Bey fell into such a rage that he passed out and was unconscious for three hours. Doolittle thought changes were beginning to happen so that the Prime Minister would be replaced. (27)

Murphy had good reason not to want to upset the French for he and the vice-consuls had made many contacts with anti-Axis French groups. A member of one of these groups, called the Group of Five, was Jacques

Lemaigre-Dubreuil, an industrialist married to a peanut oil heiress. He was a right winger and a partner of the Banque 
Worms. Because of his right wing connections, he was above suspicion and allowed to travel freely between North Africa and the mainland. Lemaigre-Dubreuil and his group, who were anti-German, wanted to establish a French African provisional government that would be independent of metropolitan France. Their plan was to cut all communications with mainland France. They were looking for a leader as well as for arms from the United States. Both Eddy and Murphy wanted to supply arms to this group, but Donovan refused because he considered their demands for arms excessive. For the most part, the men with whom Murphy was working were part of the military with conservative or even royalist sympathies. (28)

In April when Murphy and Eddy were beseeching washington for these supplies, they stressed the possibility of a German landing in North Africa. While this never materialized, another ominous development occurred when Pétain, under German pressure, brought Laval back as vicepremier of the Council of Ministers in April 1942. There were various suppositions about the reason for this. In North Africa Murphy heard it was because the Germans wished to protect their rear as they fought the Russians. (29) Another possible explanation was that the Germans did not trust Darlan, who remained as commander-in-chief of all lanò, sea, and air forces.

As early as February a member of the French foreign office had told Leahy that the anti-Americanism of Darlan 
had been changing because of recent demands by the Germans. Leahy, himself, attributed the change in attitude to the German trouble with Russia, believing Darlan would "shift from side to side with the changing fortunes of war." (30) As a matter of fact on April 14, just as Laval was being brought back in Vichy, Murphy had dinner in Algiers with Darlan's son, Alain, and Admiral Raymond Fénard, who had taken over some of Weygand's functions upon the latter's recall. From them Murphy learned that Darlan and Pétain were convinced of an American victory and wanted to be on the United Nations side as they thought, Murphy reported, the United States stood for the restoration of the French Empire. (31) This belief on the part of the French authorities may have come from the communications from Roosevelt when he was urging them to withhold their fleet from the Germans if they wanted United States help in regaining their overseas possessions. It could also have come from State Department representatives in France. In his memo to Berle and Welles of April 7, Alling had referred to "our announced desire to have the French preserve the status quo of their existing colonies." (32)

The return of Laval caused an outburst of indignation from the United States. Aid was stopped and Leahy was recalled, though diplomatic relations weren't broken. As Hull told the French Ambassador in Washington, since Laval had openly and publicly announced as his policy intimate cooperation between France and Germany obviously the united States could not maintain the same kind of relations with the 
government of Laval as with the preceeding governments. (33)

Even before his recall Leahy in a letter to welles had questioned whether the United States was following the right course in supporting the Marshal and whether it might not be better to support the dissidents. (34) Welles replied that the United state was supporting the Free French in areas they controlled while at the same time trying to keep Vichy from giving away the French fleet or making its territory available for Axis military operations. (35) While Leahy believed that Laval was willing to go as far as practicable in collaborating with Germany and aiding in the defeat of Bolshevism, at the same time he wanted to maintain good relations with the United States. Foreign Secretary Anthony Eden observed to Freeman Matthews, the American charge d'affaires in London, that he believed Laval still hoped to play the role of "mediator" between Germany and the united states and to play an important part in the establishment of the German New order to obtain a fairly favorable position in it for himself and France. Eden continued

I have good reason to know Laval very well indeed and regard him as a typical French deputy. He views the whole international political scene from the point of view of getting two polticians of opposite views into the same lobby. (36)

In France Laval's return meant harsh measures against the Jews and conscription of French labor for work in Germany. In North Africa a visit in February by Interior 
Minister Pucheu was viewed by some of Murphy's contacts as a step toward incorporation of French North Africa in a scheme of active collaboration with the Axis. (37)

Though Pucheu's visit to Tunisia was greeted with indifference by the populace and even some incidents such as cries of "vive Weygand", closer collaboration was evident even before Laval's return. There was a new Prefect of Police, a Monsieur Philip, accountable only to Vichy, and four or five hundred new special police from France, who had introduced "veritable Gestapo methods . . . including tortures of various kinds." The condemnation of the thirtyfive Destourians had been based on evidence secured by these means. (38) The new police had even gone so far as to approach Doolittle's chauffeur to report on his movements and visitors. Being a Tunisian, the chauffeur was worried what the police would do to him for not complying. (39)

Since December 1941 the French press in Tunisia had been stringently controlled. The press was magnifying British inefficiency and leaving the impression that France had no help except from Germany, "on condition, of course, of furnishing workmen for German war factories and becoming a source of raw material for those same factories." By jamming radio stations the Germans were keeping any news from American and British radio from the French people. With so little unbiased news, many people were concluding that Laval was the only person able to save France. (40) There was nothing that the Americans could do to 
counteract this propaganda except by word of mouth and by passing out copies of American and British speeches. Of course, this could endanger those found to possess them. Increasing the power of the short wave radio, Doolittle thought, would be useful.

While the French government in Tunisia was becoming more collaborationist, the Beylical government was becoming more nationalistic. With the old Bey's death and the investiture of Moncef Bey in June 1942, changes occurred in Tunisia that were to have repercussions far beyond what might have been anticipated. Moncef, who was over seventy, upset the old comfortable relation between the Residency and Beylical Court, or as Doolittle described it:

After having been for many years like the interlocking parts of a well oiled universal joint the French and Tunisian Administrations are now tending to separate and run, if not on opposite, at least on parallel lines. (41)

At the time the French were not in a position to counter this trend, but before a year passed they were able to make a demarche that would affect not only the Bey and the Tunisians, but cause differences among the American diplomats.

According to Doolittle, the new Bey planned to be the "champion of his people" unlike the former Bey, who was primarily concerned with "squeezing what he could from the French Administration in return for his conformity with their ideas." (42) Moncef was very popular and wherever his carriage appeared, he was surrounded by what Doolittle 
called "cheering crowds of Arabs" (43) and what Esteva called "a cortege of half-starved urchins." (44) The Tunisians would even knock off the hats of Frenchmen passing by who failed to show the proper reverence. Moncef was determined to regain his sovereignty as set forth in the early treaty of the Protectorate. According to Doolittle, it had become almost a "mania" with him. (45)

While Doolittle understood the Bey was prepared to be friendly with the Americans, this was difficult because of the jealousy of the French Administration which tried to keep all foreigners away from the Bey and his counselors. It was not too long, however, before Doolittle managed to establish friendly relations with the Bey by selling the Bey's son an oldsmobile car that he had acquired from the previous consul and by attending some marriages in the Beylical family. Because the car was sold at a very low price, the Bey felt Doolittle had almost made a gift of it. (46)

While relations between Doolittle and the Bey were good, those between the Bey and the Resident General became increasingly strained. The first difficulties arose over the application of the anti-Jewish laws. The Bey succeeded in persuading the Residency to postpone publication of the decree prohibiting Jewish doctors from practicing, but then in revenge the Residency soon published a list which stopped from practicing all Jewish doctors who had anything to do with the Beylical family. 
Shortly thereafter the Bey gave an interview to a Tunisian newspaper in which he said "he wished to see all his subjects treated equally without any distinction." (48) When the censors eliminated the words "without any distinction", the Bey made such a commotion that the article was reprinted in full with the phrase inserted. According to Doolittle, this did away with the French claims that the anti-Semitic laws had been applied in Tunisia "as a sop to the Arabs." (49) Consulate members had not met any Tunisians who approved of these laws.

The Bey proceeded to upbraid Admiral Esteva for having eliminated all his personal Jewish doctors from the list of Jews allowed to practice in Tunis. Three out of four of the Bey's personal physicians were Jewish. He told the Resident that if something were not done about it, he was ready to fly to France and see Marshal Pétain. As Doolittle expressed the Bey's sentiments:

If the French at German instigation insisted on anti-semitism, let them do it in France not here in Tunisia where for him all Tunisians were alike whether Jews or Moslems. (50)

When a Tunisian general who acted as a liaison officer between the Resident and the Bey tried to get the Bey "to lower his tone," (51) the Bey was so furious that he called him a traitor, had him taken from the palace, saying he never wished to see him again.

Esteva was caught between carrying out vichy orders on the Jewish question and pacifying the Bey. He wired Laval that the Jewish doctors were indispensable to the Europeans 
as well as the Tunisians. Not a single Jewish doctor would be excluded if he agreed to the wishes of the people. He had limited to twenty-three those who could practice without restrictions, but he was going to be obliged to allow others to "exercise their art." (52) The Bey and his entourage had demanded a half dozen of these doctors and Esteva had allowed it, not just to be agreeable, but because it would be useful to most of the population. (53) A three month postponement of the decree prohibiting Jewish doctors from practicing finally settled that problem.

Moncef Bey, however, continued "to add gray hairs to the overburdened head of Admiral Esteva", as Doolittle put it. (54) Moncef who was sympathetic to the nationalist cause became its exponent. Moncef's principal counselor was his brother, Hussein, who was closely linked to the Destourians. According to Esteva, though Moncef was on the throne, Hussein had the brains. Whether or not this was true, both brothers wanted to resume the policy of their father, Naceur Bey, of twenty years before which meant asking France for a program of reforms. Hussein believed that the time had come to give the educated youth a place in the administration as well as in all political, economic and social activity. (55) The Bey gave Esteva a letter for Marshal pétain along with a sealed packet of demands on the French Government. Among these were the creation of a system of Franco-Tunisian primary schools, imposition of quotas on Tunisian raw materials to be exported, reduction of the number of French 
functionaries, and equality in number, grade, and salary between French and Tunisians, and reestablishment of the civil and administrative powers of the caids by the suppression of the Franco-Musulman Agreement of 1892. At the beginning of the protectorate until 1892, the caids had been the real administrators. (56)

In writing Laval, Esteva remarked that because of the fall of France, the French no longer had the same freedom of action as with Naceur Bey. Esteva thought the French had little choice but to agree to take progressive steps toward granting Tunisians access to jobs in the administration. (57)

pétain, however, gave Moncef Bey little satisfaction, writing him that tradition in the Protectorate had taken on the force of law. He continued:

Admiral Esteva has a heavy task, especially now. The former Bey thanked him many times in terms which showed the friendly esteem in which he held him. Your Highness should in turn witness toward him the same sentiments. (58)

Nevertheless, Esteva, who made a "hurried trip to Vichy" (59) because of his difficulties with the Bey, was authorized to accede to some of his demands, though not to suppression of the 1892 agreement.

While Esteva blamed the Destourians for being the ones in the Bey's entourage counselling him to change the status of the protectorate, he reported that most of the Destourians were supported by "our parties of the extreme left, by the Free Masons and by the Jews" (60) - the 
traditional enemies of the French right.

As for the Americans, Esteva wrote that "the protagonists of Tunisian independence" (61) had been in contact with them. He reported, however, that when the Bey and Hussein had sent a Tunisian to the American Embassy to ask the American consul to come see them to have a secret conversation with them, Doolittle had replied that he would reflect. Esteva learned that Doolittle expected to ask the Resident General to arrange an interview with the Bey. Esteva concluded by stating that "he begins to be circumspect." (62) Obviously both Doolittle and Esteva had to tread a careful line. For Esteva it was between the Tunisians and Vichy while for Doolittle the line was between the French and Tunisians.

Though the demands did not seem unreasonable, Doolittle felt the Tunisians were not prepared to be "directors of a budget, allocators of raw materials, or members of the council of administration of a large company." (63) In Doolittle's opinion the French educated Tunisians had lost their own traditions, but had not fully grasped those of the Europeans. As a consequence they felt like Europeans with the Tunisians, and like Tunisians with the Europeans. Many turned to alcohol and most of the younger ones were spoiled. Their fathers, however, hung on to "too much of the Arab tradition to be able to compete in a capitalistic and imperialistic world." (64) 
Difficulties between the Bey and Resident General became even worse during Ramadan at a ceremony at which the Bey received European notables and asked many provocative questions of the French. To Philip, Prefect of Police, he asked where were the Tunisians in the police administration. To the Director of Public Instruction he said that he hoped in the future there would be no more French lycées, but only Franco-Tunisian schools. (65)

After the ceremony the Bey left for his special train to return to his palace at La Marsa. At the station there was an honor guard of Tunisian troops under a French officer who performed so well that the Bey sent his adjudant to give the officer a thousand francs and the soldiers four thousand. When the officer said he couldn't accept tips, the Bey said this wasn't a tip, but a reward for their good appearance. (66)

This incident just increased the Bey's dislike of Esteva to the point that he gave the Residency a telegram for Marshal Pétain asking for the recall of Admiral Esteva as Resident General. Admiral Esteva had visibly aged from all of this. He had always had a slight nervous tic, but now it was causing his head to wave "from side to side in a manner which aroused pity." (67) The state of tension between the French and the Tunisians had reached an explosion point.

It was obvious to Doolittle that the French were "losing their grip on the Arabs." (68) Even the French 
police had been forcea to relax their harshness. Doolittle thought it not surprising when Axis radio propaganda was pointing out to the Tunisians that, since "the French themselves were a protected nation, the Arabs should get their protection direct from the source without any intermediary." (69)

The Italians were all too ready to take advantage of the troubles between the Bey and the French. Through their broadcasts, they were assuming the attitude of the "great Eriend of all Islam." (70) Doolittle reported that they were "watching the situation like hawks and would be prompt to intervene if any disorders should occur." (71)

In the summer of 1942 Doolittle had received from a confidential source a copy of Italian plans for Tunisia once victory had put them in charge there. Doolittle forwarded a copy of the document to the state Department with suggestions of how it could be used as counter propaganda by having copies made for distribution to Tunisian leaders. Doolittle thought that letting the Tunisians see what the Italians planned for Tunisia would have the effect of turning them against the Axis. The state Department forwarded the idea on to the Office of Strategic Services who were interested in the project and provided $\$ 2500$ for it. $(72)$

Just as the situation between the Bey and Resident General was about to explode, another explosion occurred involving all of North Africa - the American and British 
landing. Problems between the Bey and Protectorate were not over, only postponed for six months. 


\section{NOTES}

CHAPTER IV

1. FRUS 1942 II, 127-128.

2. Ibid, $128-129$.

3. Ibid, 147-148. d'orsay.

4. Esteva to Darlan, April 15, 1942, P-3-5, Quai

5. Ibid, December 22, 1941.

6. FRUS 1942 II, 130.

7. Ibid, 139 .

8. Ibid, 246 .

9. William Langer, Our Vichy Gamble (New York: Knopf, $1947), 276$.

10. Doolittle to Hull, January 27, 1942, 8515.00/199.

11. Ibid.

12. FRUS 1942 II, 226-227.

13. Doolittle to Eddy, February 25, 1942, 8515.00/203.

14. Ibid.

15. Murphy to Doolittle, March 4, 1942, 8515.00/203.

16. Murphy to Murray, March 4, 1942, 8515.00/203.

17. Ibid.

18. Ibid.

19. Alling to Doolittle, April 19, 1942, 8515.00/203.

20. Alling to Berle and Welles, April 7, 1942, 
$8515.00 / 203$

21. Carleton S. Coon, A North African Story: The Anthropologist as oss Agent 1941-1943 (Ipswich,

Massachusetts: Gambit, 1980), 130 .

22. Ibid.

23. Doolittle to Alling, May 9, 1942, 851S.00/209.

24. Ibid.

25. Ibid.

26. Doolittle to Murphy, March 17, 1942, 851S.00/209.

27. Ibid.

28. Langer, Our Vichy Gamble, 228 .

29. FRUS 1942 II, 287.

30. Ibid, 145 .

31. Ibid, 283.

32. Alling to Berle and Welles, April 7, 1942, $8515.00 / 203$.

33. Frus 1942 II, 172 .

34. Ibid, 146 .

35. Ibid, 155 .

36. Ibid, 174-175.

37. Ibid, 134 .

38. Doolittle to Hull, March 5, 1942, 8515.00/202.

39. Doolittle to Alling, May 9, 1942, 8515.00/208.

40. Doolittle to Hull, July 6, 8515.00/210.

41. Doolittle to Hull, September 9, 1942, 851S.00/225.

42. Doolittle to Hull, July 6, 1942, 8515.0011/6.

43. Ibid.

d'orsay.

44. Esteva to Laval, August 18, 1942, P-4-1, Quai 
45. Doolittle to Hull, September 9, 1942, 851S.00/225. 46. Doolittle to Hull, July 29, 1942, 8515.00/217.

47. Ibid.

48. Ibia.

49. Ibid.

50. Doolittle to Hull, August 5, 1942,8515.00/214.

51. Ibid.

52. Esteva to Laval, August 21, 1942, P-1-1, Quai d'orsay.

53. Ibid.

54. Doolittle to Hull, August 19, 1942, 8515.00/218. d'orsay.

55. Esteva to Laval, August 18, 1942, P-4-1, Quai

56. Doolittle to Hull, August 19, 1942, 8515.00/218.

57. Esteva to Laval, July 30, 1942, P-4-1, Quai d'orsay.

58. Petain to Moncef Bey, September 15, 1942, P-4-1, Quai d'orsay.

59. Doolittle to Hull, September 9, 1942, 8515.00/225.

60. Esteva to Laval, September 28, 1942, P-4-1, Quai d'Orsay.

61. Ibic, September 5, 1942.

62. Ibid.

63. Doolittle to Hull, August 26, 1942, 8515.00/219.

64. Ibid.

65. Doolittle to Hull, October 15, 1942, 8515.00/234.

66. Ibia.

67. Ibid.

68. Doolittle to Hull, September 9, 1942, 8515.00/225.

69. Ibia. 
70. Doolittle to Hull, July 6, 1942, 8515.0011/6.

71. Doolittie to Hul1, October 15, 1942, 8515.00/234.

72. Doolittle to Hull, July 28, 1942, 8515.00/215. 
Chapter V

OPERATION TORCH

By July of 1942 the United Nations renewed plans for the North African invasion. Because the Russians urgently needed the relief a second front would afford, president Roosevelt had promised one to stalin before the end of the year. While both General George Marshall, Chief of Staff of the Army, and Henry Stimson, Secretary of War, preferred a direct cross-channel attack, Churchill, hoping to relieve pressure on Egypt where Rommel was advancing, opposed this and proposed invading North Africa instead. Tobruk in Libya had fallen to the Germans in June, a serious setback to the British. The Joint Chiefs of Staff, meeting in London, decided on July 24, 1942, on the North African invasion given the operation name "Torch". On learning of the decision, Roosevelt wired that the landing be made no later than october 30, 1942. The British insisted that the supreme commander be an American, and General Eisenhower was chosen for this position. The British had, also, insisted that the expedition be led by united States troops, even though British troops would be used, because of their hope that Americans would meet with less resistance. Churchill even wrote Roosevelt that the British might wear American 
uniforms.

We have plenty of troops highly trained for

landing. If convenient, they can wear your

uniform. They will be proud to do so.

The invasion ran the risk of bad weather en route and it ran the risk of submarine interception. The main risks, however, were the responses of the French and of the Spanish. Of utmost concern was how the French military in North Africa would react. Robert Murphy, in a talk with FDR at Hyde Park on September 4, 1942, found that the President was keenly aware of the delicate situation which would result from sending American troops into the colonies of an avowedly neutral government with which the United states had friendly relations. In light of stated American principle, it would be hard to establish a case for landing in French Africa without the approval of the Vichy government. Without the consent of petain's government, the united states could expect a military landing to be resisted with force by some of the French military who had sworn allegiance to petain. Murphy pointed out to FDR that there were only two possibilities for overcoming French resistance. One was to send United Nations troops and equipment vastly superior to that of the French forces already there. The second was to persuade the French military by diplomatic means that victory over the Nazis would result from working with the United states and that loyalty to France was more important than loyalty to Pétain. The first alternative was out. As Eisenhower wrote to his aide, Captain Harry C. Butcher: 


\begin{abstract}
However, study had conclusively shown that it was impossible to build up a force of sufficient strength to make tactical considerations the governing ones in undertaking this operation . . . measured purely from a military standpoint the risks of the projected operation were so great as to condemn it if military factors alone were considered. (2)
\end{abstract}

Both FDR and Eisenhower were aware that the second alternative was the only feasible one. Eisenhower continued to Butcher:

Consequently, the whole campaign had to be considered as depending entirely upon political factors - - that is, upon the accuracy with which our political leaders could foresee the reactions of the French and Spanish armies in North Africa to this landing. (3)

Eisenhower went on to describe to Butcher that the American Chiefs of Staff, around the middle of August, had proposed attacking only at Casablanca and oran in order to secure the land-line of communication running between these two in order to decrease the dependence on Gibraltar. However, should the French resist, so much damage could be done to this route as to prevent its use for some months. Thus Eisenhower reemphasized the need for French co-operation:

This fact again brought to the fore the certainty that success depends upon non-resistance on the part of the French Army. (4)

The President named Murphy the sole agent in charge of political maneuvers in North Africa, and he was given the task of persuading the French Arny not to resist the landing. Once the invasion took place, he would act as 
Operating Executive head of the Civil Affairs Section and Advisor for Civil Affairs under General Eisenhower. Murphy was to contact members of the French military whom he considered reliable, inform them of a contemplated American landing, and try to obtain their assistance. After preparations were made by those French aiding the Americans, at least twenty-four hours notice would be given them. He was to give the French the assurance that the administration of the colonies would remain in French hands. Another risk and unknown factor was what the Spanish would do. In fact, General Mark Clark, Eisenhower's Deputy Commander, wrote that, "There was, perhaps, more worry about the Spaniards than the French." (6) Should Franco decide to intervene because of Spanish interests in Morocco and sympathy with Hitler, spanish troops might easily take over Gibraltar, which Eisenhower had chosen for his temporary headquarters.

Not the least of the worries was what the Germans might do. Did they have enough troops to deflect to North Africa? Throughout the months preceeding the landing, there were constant rumors that the Germans were about to send forces to North Africa. This added pressure for speed on the part of those planning the invasion.

In planning "Torch" Eisenhower needed to find a French leader around whom the French military would rally. He considered the possibility of using de Gaulle, but he feared that de Gaulle's presence in the initial landing 
would cause the opposition of the French garrisons. The consuls and vice-consuls in North Africa reported that the regular French army corps considered de Gaulle a disloyal soldier. His standing with the resistance elements of the civilian population was quite different, but the first priority was winning over the armed services. (7) In fact, Roosevelt insisted that de Gaulle and the Free French not be told in advance of the invasion for fear they would not keep it secret. As Churchill wrote Roosevelt on september 3, "Free French have got inkling and are leaky."

The logical leader woula have been General Weygand, then living in retirement in the south of France. Weygand, however, refused out of loyalty to pétain when asked by an American representative to go back to North Africa and assume command there with full American military support. Although anti-German, Weygand was opposed to any dissident action against pétain. While weygand had refused, another military man had come to the attention of the Americans.

Back in May 1942, Murphy had learned about General Henri Giraud from the Governor of Algiers, Yves Chatel, who had just returned from Vichy where he had lunched with Petain and Giraud. Giraud, a man in his late sixties, had recently escaped from a German prison, the fortress Königstein, "by climbing down an improvised ladder some 150 feet." (9) Reporting on the luncheon, Murphy wrote cordell Hull: "Chatel says Giraud is as ardentiy anti-German as ever. He also said that Giraud would be glad to work with 
the Americans." (10)

Besides Chatel's recommendation of Giraud, the Americans had other evidence of Giraud's loyalty to the United Nations side. The Co-ordinator of Information had received a copy of a letter that Giraud had written his children from prison encouraging them to remain faithful to France and to do all in their power to hasten its deliverance from the Germans. To some extent the decision to approach Giraud was based on this letter, a copy of which Donovan had sent to Roosevelt.

Murphy managed to contact Giraud with the help of Lemaigre-Dubreuil. The latter, on one of his trips to the mainland, met with the general in Lyon and found that he was already making plans for the day when the united States would invade France. He agreed to lead if the Americans met several conditions. One of these was that a French officer be in over all command and by this he meant, of course, himself. Another condition was that an invasion of mainland France take place at the same time. Giraud also wanted Lemaigre-Dubreuil on his return to Algiers to contact his old friend, General Charles Mast, Chief of Staff of the French XIX Corps in Algeria, and ask him to serve as his representative in North Africa. Mast had been instrumental through the French intelligence service, the Deuxieme Bureau, for arranging Giraud's escape from Germany. At a meeting at Eisenhower's hide-away, Telegraph Cottage, outside London on September 16-17, Eisenhower and 
Murphy decided that on his return to North Africa, Murphy suggest to Mast that he send a message to Giraud that the United States was now able to take action on a substantial scale and ask whether he was willing to act. Should Giraud decide to come, the question of French command in North Africa would have to be settled. Giraud's friends "had always made the point that the command in North Africa must be French. On this point Eisenhower said that the question of command must wait." (12)

Murphy may have mentioned at Telegraph cottage that he had also been getting feelers from Admiral Darlan about joining the United Nations side. Back as far as August 1941 Darlan had told Admiral Leahy, at that time the American Ambassador to Vichy, to talk to him when the United States would be able to send five hundred thousand men and several thousand tanks and planes to Marseille. (13) Leahy, as has been mentioned, considered Darlan an opportunist who "endeavored to walk a tightrope between the warring parties." (14) After Darlan's replacement by Laval in April 1942 as vice-premier, William Donovan suspected that Darlan's ardour for the pétain government might have cooled and considered enlisting his help for the United Nations. In a memo to FDR he asked:

Would you think it fantastic, and if not, is it feasible to have someone who is close at Vichy talk with Darlan? His nose must be greatiy out of joint at this moment. (15)

As a matter of fact it was at that time that Darlan made an overture to the United states through Admiral Raymond Fénard 
and his son, Alain, to Murphy. Then, in the middle of October, a friend of Darlan's urgently requested a secret interview with Murphy. Murphy learned that Darlan was considering joining the United States side. Darlan's representative asked if l) the united States would be willing to co-operate with Darlan and 2) if so, would it be able to do so quickly on a large scale here and/or in Europe. In reporting this message to the war Department, Murphy urged that the United States encourage Darlan and stated that he believed this would be "reconcilable with eventual co-operation with Giraud." (16) In reply Leahy, now Roosevelt's Chief of Staff, wired Murphy that he should make any arrangement with Darlan that would assist the military operations. (17) Leahy told Murphy:

Inform your contact we also have information that Germany contemplates occupation of African Colonies and it is our opinion that Darlan should resist aggression by Axis with Army and Navy in which event America will provide at once large scale military material, and economic aid in the colonies. (18)

In a cable to Marshall on the same day, October 17, about the Darlan proposition, Eisenhower wired:

Giraud to be recognized as our principle collaborator on the French side, with the proposal that he accept the position immediately of French Governor of all French North Africa, responsible for all French civil and military affairs, and whose position will be supported and protected by the Allied Forces. Giraud to be requested to make proper contacts with Darlan and to accept him as Commander-in-Chief of French military affairs, and/or naval forces in North Africa or in some similar position that will be attractive to Darlan. (19) 
In this same cable Ike told Marshall that he was sending Mark Clark and four assistants on a secret mission by submarine to Algiers to meet with Mast no later than October 21 .

Mast had requested the meeting and had specifically brought up the question of command. In a telegram to the war Department, Murphy said: "This is a question I have dreaded because of French susceptibilities." (20) Mast insisted that French command would be necessary, since the French forces knew the terrain. Murphy asked the war Department if they had "a happy formula for this delicate point." (21) Mast, also, brought up Giraud's idea which was "dear to his heart" that a simultaneous attack on southern France be made. Finally, Mast had heard that Darlan was seeking to climb on the bandwagon, but in his opinion Darlan could not be trusted. Mast asserted that "Giraud's command will give us entry practically without firing a shot." (22) This last assertion would turn out to be quite wrong and would play a significant part in Darlan being given the leadership.

The meeting that Mast had requested took place on October 22 with a good deal of drama. The place chosen was a private house at Cherchell on the Algerian coast 150 kilometers west of Algiers. The servants of the owner had tipped off the police that something was happening. When the police arrived, looking for smugglers, the Americans had to hide quickly in the wine cellar. When they left the conference for the submarine which had brought them, the 
waves were so high that the "entire group was thrown into the sea and money, equipment and clothes were practically all lost." (23) While clark obtained much useful information from Mast, such as details of troop locations, batteries, and installations, the question of command was troublesome and left unresolved. In writing Marshall about the conference, Eisenhower said, "I will have to ride a rather slippery rail on this matter. . ." (24) Furthermore, the opportunity the Americans "had hoped for of getting Giraud and Darlan together on the proposition went glimmering." (25) Mast, Eisenhower wrote, "believes that Darlan is not to be trusted and that Giraud will have nothing to do w1th Darlan." (26)

Because of the need for secrecy it was decided not to tell the French when the invasion would take place, only that they would be given four days advance notice. Murphy wired the War Department:

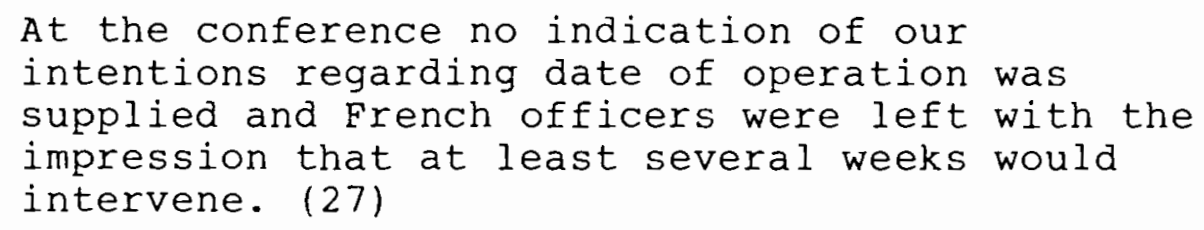

Since the date of the landing was now scheduled for November 8, Murphy found that Giraud could not leave France in time to be in Algiers for it and requested a delay. The request was refused because convoys had already left the United States, and could not be turned back.

Besides being in touch with the French military leaders, Murphy was hoping to obtain the cooperation of the 
French and North Africans by stepping up shipments of economic aid. While aid had stopped when Laval returned, it had been resumed in June. With the invasion imminent, Murphy believed it was crucial for the success of the landing. He wrote to the state Department:

I believe the Department will appreciate without much comment from me the propaganda value of the arrival of these ships in Algiers from New York loaded with American goods for the benefit of this area. (28)

When Murphy was in washington in late september after his meeting with Eisenhower at Telegraph Cottage, he pleaded for supplies for North Africa to arrive before the landing. While Roosevelt did everything he could to see that they arrived and Leahy said aid was to be sent with out any quid pro quo, simply to gain French friendship, the Board of Economic Warfare did not get them there in time. Since they could not be let in on the plans of the invasion, it was hard to convince them of the urgency of the need. Furthermore, they feared the supplies would fall into Nazi hands and were reluctant to ship them at all even with "an order from FDR in his own handwriting." (29)

Besides economic aid, diplomatic preparations for the invasion were concerned with an effort to see that spain and Portugal were kept reassured as to the United States' intentions and that spain would maintain her neutrality and prevent a German march through the Iberian peninsula to Gibraltar to attack the united states troops in the rear. 
Spain was told that increased economic aid "would be possible only so long as spain stayed out of the war and did not allow the Axis to infringe upon her territory." (30)

Furthermore, the French commanders were to be instructed not to take any retaliatory action on D-day against the Spanish should there be incidents, until after the consolidation of the American forces. (31)

In the meantime, messages were beomg drafted from the President to General Franco, President Carmona of Portugal, Marshal Pétain, Governor General Yves Charles Chatel of Algeria, General Auguste Nogules, the Resident General of Morocco, the Sultan of Morocco, Admiral Jean Pierre Esteva, the Resident General of Tunisia, and the Bey of Tunisia, Sidi Moncef Pacha. These messages said that German and Italian troops were planning to invade and occupy North Africa and that a powerful American force was being landed in North Africa to co-operate with the Governments of Algeria, Tunisia, and French Morocco in forestalling this threat. Harry L. Hopkins wrote that:

The final stages of preparation for TORCH involved a great deal of very careful word choosing for the various messages from the President. . (32)

on reading FDR's proposed letter to Pétain, churchill wrote the President:

Will you allow me to say that your proposed message to petain seems to me to be too kind? . . Will you consider toning it down a bit? (33)

A leaflet containing a message from President 
Roosevelt to the people of North Africa was also prepared. It contained a color imprint of the American flag as well as the President's photograph and was to be dropped from planes from Gibraltar at the time of the first attack. (34)

Messages were prepared to be broadcast by radio both in unoccupied France and North Africa as well as from the ships that were to provide the protective cover for the landing forces. The President's statement which was printed on the leaflet and which was to be broadcast stressed the friendship of the United States for the French people. This kind of psychological warfare was a new tactic being tried out in North Africa. Roosevelt, himself, worked on these messages. Afterwards, Eve Curie wrote FDR complementing him to which he replied:

May I tell you that I am glad you liked my straightforward French . . no beautiful phrases, nor oratory . . I thought, however, that I ought to be myself and the French people would understand my normal simplicity better than if I did something which was not a part of me. (35)

In spite of the careful preparations for the invasion, things did not go as planned. Giraud, who had been picked up by submarine, instead of going directly to North Africa, stopped in Gibraltar where Eisenhower and his staff had set up their headquarters just thirty-six hours before D-day. While the landings were taking place, Giraud was arguing with Eisenhower and Clark about the command. He refused to participate except as supreme commander.

Eisenhower thought that Giraud was playing for time, that he 
knew the Americans could not grant his request, but was waiting to see if the United Nations landing was successful. Eisenhower wrote Marshall that he and Clark were bitterly disappointed about his attitude. (36) Giraud finally left for Algiers on November 9 , thirty-six hours after the landings began. He was to do his utmost to stop resistance to the United States troops and to begin to organize the French forces for employment against the Axis. Eisenhower had made concessions to Giraud, but he would, of course, not turn over the position of supreme commander to him, nor would he promise a simultaneous landing in southern France. The military operation did not go as planned either. The Joint Chiefs had decided on attacking Casablanca, Oran, and Algiers. In explaining this decision, Eisenhower said a direct landing in the Bizerte-Tunis area would have been desirable, but that area was beyond the range of fighter aircraft support. Besides the British had had disastrous results running convoys to Malta. Though the Joint Chiefs had decided the Tunis-Bizerte area was too risky for a landing, Eisenhower, believing that Tunis was so important that the United States should land as far east as Bone, wanted to attack Oran, Algiers, and Bone. This, however, was overruled because the chiefs of staff thought the railroad between Casablanca and Tunis was an important supply route and to ensure its operation the Casablanca landing was necessary. This decision meant that the early capture of Tunis was less likely. Once the Moroccan and Algerian 
landings had occurred, the American forces were to protect the rear in Morocco while the British First Army under Sir Kenneth Anderson, which was to land at Bougie, Djidjelli, and Bone in Algeria, would rush eastwards to Tunis. (37)

In meeting with Eisenhower, Murphy had warned him that the greatest resistance would come from General August Nogules in Morocco. Stopping to see Nogues on his return to North Africa from the United States, Murphy had tried to win him over, but without success. Nogues, fearing an invasion would cause chaos, wanted to preserve the status quo. He did not want to see French authority disintegrate because that would cause North African nationalism to rise. (38)

When the landings began on November 8 , Nogules ordered the French troops in Morocco to resist the invasion. In Oran the lieutenant colonel in charge of the resistance had had cold feet and divulged to his chief what he knew about the American operation. The chief immediately prepared to resist the landing and as a consequence the United Nations faced serious fighting at Oran. Only in Algiers, where Mast and the Group of Five had successfully organized the resistance, was the fighting minimal.

In the meantime, another unexpected development was the arrival in Algiers of Darlan to see his son, who had entered the hospital with infantile paralysis. Thus while the landings were occurring and Giraud had not arrived, Murphy asked Darlan for his co-operation. Though rellictant at first, Darlan agreed to seek the authorization of Petain, 
to whom he arafted a message. General Alphonse Juin, who had been commander of the French armies in North Africa until Darlan's arrival, urged the latter to cease the hostilities. According to Mast, it was Juin who sanely judged the situation, refused to continue the fighting in spite of Darlan's stubbornness and whose intervention finally made Darlan order a preliminary cease fire. (39) In signing the cease fire, which was only for Algiers and its suburbs, Darlan claimed to have received a message in secret code from petain of his approval of Darlan assuming authority in North Africa. It was Murphy who negotiated with Darlan until Mark Clark flew in on November 9.

When Clark arrived, he was upset about the Darlan agreement because he and Eisenhower had just negotiated an agreement that morning with Giraud. However, when Murphy and Clark met Giraud in an automobile so as not to be heard, Giraud had already met with the high ranking French officials and had learned that most of them considered him a dissident. As Churchill put it: "The reception of Giraud by the leading French commanders was icy." (40)

Giraud told Murphy and Clark that he wanted to be free to devote himself to combat. He also said he would be content to work under Darlan. Giraud wanted "an arrangement by which the Admiral would be a sort of High Commissioner, while he, Giraud, would become commander-in-chief of the French forces." (41) Giraud, thus, without any persuasion from Clark or Murphy, provided what proved to be an 
effective formula for the early weeks of "Torch".

The surprise for the Americans in regard to Darlan was the fact that the French officials looked to him as the man with the greatest authority in North Africa. Mast and others who had co-operated were looked upon as traitors by other French officers whose help was needed. Giraud told Clark that only Darlan could issue a general cease fire order that would be obeyed.

When Nazi troops started moving into unoccupied France on November 12 in violation of the 1940 armistice, the last obstacle to an agreement was overcome. As a result Darlan decided that pétain was no longer a free agent and agreed to cooperate with the United Nations. Clark persuaded Darlan, using a bit of bullying, to give an order to the French troops and the navy to stop fighting. He issued the order in the name of Marshal pétain and it was obeyed. As Eisenhower wrote, "The fighting at Casablanca had ceased because of Darlan's order: at other places the fighting was over before the order was received." (42)

The name of Marshal petain carried far more weight with the French military in North Africa than the Americans or British anticipated. The authority of the state was vested in him, and it was to him they owed their allegiance. Darlan wore his mantle. As Kenneth Pendar, one of the viceconsuls described it, most of the French in North Africa had an almost mystic faith in petain and most of the military there were ready to follow the "head of the state." (43) 
Once France was occupied by the Germans, Pétain was no longer a free agent and the military could transfer their allegiance to Darlan. Since the Germans had broken the armistice agreement, Darlan felt free to co-operate with the Americans.

On November 12, the French agreed among themselves on a formula for the French command. It was basically the same one Eisenhower had proposed in the middle of October. On November 13 Eisenhower flew in from Gibraltar and received word that the French had agreed. Darlan would head the civil government, the present governors would remain at their posts, Nogues in French Morocco and Chatel in Algeria, while Giraud would head the French armed forces. Eisenhower came to the meeting and shook hands. The "Darlan deal" was thus consummated. While Mark Clark and Murphy had been part of the early discussion, it was Eisenhower who took the final responsibility for the "deal". According to this arrangement, the United Nations stated they would not disturb the French administrative control of North Africa, provided the French forces and the civilian population would obey Darlan's orders to co-operate militarily with the United States. (44)

This "deal" brought a storm of protest in both the British and American press because of Darlan's connection with Vichy and his pro-Axis politics. To explain more fully the situation, Eisenhower sent a long telegram to the Combined Chiefs of staff in which he explained: 
Foremost is the fact that the name of Marshal Petain is something to conjure with here. Everyone from highest to lowest attempts to create the impression that he lives and acts under the shadow of the Marshal's figure. The civil governors, military leaders and naval commandors agree on only one man as having an obvious right to assume the Marshal's mantle in North Africa. That man is Darlan. (45)

Eisenhower also stated in the wire that it was important to have a strong French government in North Africa.

Otherwise the United States would need a large occupation force.

FDR was convinced that Eisenhower had acted correctly in view of the unanticipated situation in North Africa and cabled him that he would back him to the hilt. On November 17 the President issued a public statement saying that he "accepted General Eisenhower's political arrangements made for the time being in North Africa and Western Africa." (46) But he went on to say: "The present temporary arrangement in North and West Africa is only a temporary expedient, justified solely by the stress of battle." (47) Roosevelt said it was made "to save American and British lives and to avoid a mopping up period in Algiers and Morocco."

Needless to say Roosevelt's statement caused problems for Eisenhower. Darlan, on hearing about it said:

Information coming from various parts tends to give credit to the opinion that 'I am but a lemon which the Americans will drop after it is crushed.' (49)

Darlan proved to be very co-operative. He did order the cease fire and stopped the fighting on the western coast though he was unsuccessful in stopping it in Tunisia. While 
he had never guaranteed that he would be able to bring the Eleet over to the united Nations side, he tried and did say that the French admiral in Toulon would never allow his ships to fall into enemy hanàs. As it turned out, the French scuttled the fleet in order to keep it from the Nazis. In Tunisia Darlan's order was received too late.

At two o'clock in the morning on November 8 Doolittle called at the Residency. He gave Admiral Esteva two personal messages from President Roosevelt, one for him and the other for the Bey asking for free passage for United Nations troops "which had no other object than the rapid destruction of our common enemies." (50) Esteva, who received Doolittle in full dress uniform and Turkish slippers, was terribly surprised by Roosevelt's letter even though, as French historian Albert Kammerer said, he approved of it "from the bottom of his heart." (51) However, because he was ruled by the "mystique" of obedience to pétain, he replied to Doolittle that he intended to be loyal to the Marshal. On the next day the first Axis radio broadcasts announced that important landings by the United States had taken place the preceeding night at several points in Morocco and Algeria. That evening at seven o'clock Admiral Esteva handed the Bey the President's message giving him at the same time petain's order "calling upon Tunisia to resist by all its means the Anglo-Saxon invasion." (53) The Bey quite naturally was confused by these two contradictory messages and called a council of his ministers, his close 
entourage, prominent members of the Destour and his two brothers.

The Bey's Prime Minister, the "timorous soul" Doolittle had hoped to depose in the palace revolution, advised that no reply should be given. But another "bolder soul", who was later chosen as Prime Minister by the Bey, pointed out that the French would be abandoning "the basic principle of the protectorate" (54) if they allowed the Germans to land and asserted that a reply should be made. This view prevailed and the Bey finally drafted a reply for the President that Tunisia desired to be neutral. As Doolittle pointed out, since Tunisia had no armed force of its own, "the Bey and his opera bouffe army could obviously do nothing against either one of the belligerent forces." (53)

While this was the official message given to Esteva for transmission to the President on November 13, an emissary from the Bey, who had climbed over the garden wall of Doolittle's house while the guards were distracted by the bombing of the airfield, brought him an unofficial message on the night of November 12. The emissary talked to Doolittle in the garden so as not to attract attention to his presence by going into the house and turning on the lights. In this oral message to the President, the Bey said that since peltain had taken a position against the United Nations and had put the airfield at the disposition of the Axis so they could occupy it at any moment, there was 
nothing at the moment that the Bey could do in favor of the United Nations other than to declare his benevolent neutrality.

In case, however, of a future invasion in response to an Axis landing, he would want to put at the disposal of the United Nations all the resources of the country as well as the goods and lives of his people. His Highness did not doubt that the United Nations which was waging war for justice and for the rights of the little people would treat Tunisia according to the principles of the Atlantic charter. The Bey was sure that the American government would do nothing to favor the expropriation of Tunisian territory by French imperialist elements. (56)

If the Bey was confused at the time of the invasion, Admiral Esteva also had reason to be bewildered. Esteva learned from Doolittle the breadth of the operation. Because of Vichy's policy of defending the Empire against all, the first measures in Tunisia were taken against the United Nations. Admiral Derrien, who was in command of the naval base at Bizerte, on hearing of the invasion ordered two cargo ships sunk in the harbor of Bizerte to block its use by the United Nations while General Barré, in charge of ground troops, ordered his troops to cover Tunisia from the direction of Algeria and Bone. On November 9 Axis planes were allowed to use El Aouina airport at Tunis, and were refueled as they arrived. Over one hundred Axis planes towing gliders overwhelmed the Ei Aouina airport by landing 
over one thousand men. Although a French colonel had wished to attack the arriving Germans, Barre' had opposed it and ordered his troops to abandon the airport. (57)

Adding to Esteva's confusion was the fact that he was receiving orders from both Pétain in Vichy and Darlan in Algiers. On November 11 Darlan ordered the Erench troops to oppose the Germans. Derrien informed his troops that the Germans were the enemy and they were to defend Bizerte against them. Derrien's troops received the order with enthusiasm. Esteva, however, immeaiately announced that the order had been given too hastily and that Darlan had revoked it. Strict neutrality was to be maintained and the orders of the Marshal were to be followed. The next day the order was again reversed and Barré and Derrien were told to resist the Axis, but by this time it was too late. In case Esteva had ever considered independent action, he waited too long. Beginning on November twelfth Axis troops began debarking at Bizerte and by the fourteenth the Germans occupied Tunis. While Derrien's troops may have wanted to fight the Germans, Derrien, himself, seemed to have decided not to resist. According to Mast, he gave up the naval base at Bizerte and all the ships without fighting. Besides refusing to fight the Axis, Derrien refused to let the ground troops at Bizerte witharaw to the west. Three thousand men thus were taken prisoner. The naval forces as well as the arsenal of Ferryville were delivered to the Axis who took them to Italy where they were used against the United Nations. (58) 
While Barre' had not opposed the Axis landing, he withdrew his troops westward into the hills playing for time. On the fourteenth the British army under General Anderson crossed the Tunisian frontiers to support Barre's troops who had taken a position at Medjez-el-Bab. By now the Germans had their doubts about Barré and asked Esteva to relieve him of his command. Esteva refused saying he was not authorized to do so. When the Germans ordered Barre' to fight on their side, he followed instead the orders of Darlan and Giraud saying: "The war has begun. I am the enemy of the Germans." (59) On November 19 the Germans opened fire on Barre's troops at Medjez-el-Bab and with that the Tunisian campaign had started.

According to Kammerer, Esteva, Derrien and Barré were unanimously against Germany and against all collaboration. They wanted the United Natiions to arrive, but they didn't do anything useful.

they limited themselves to sending telegrams to the point that the period immediately preceeding the Tunisian campaign . . would appear in history as a flight from responsibility of all the high agents and all the civil and military chiefs. (60)

Kammerer went on to say that the French soldiers could have prevented the landing of the planes or have decimated the parachute troops, but the French troops were prohibited from firing and the first German planes to land were refueled by French attendants at the airport. (61)

There were a few measures, however, that Esteva took 
that favored the united Nations. When the Germans arrived he ordered the prison doors to be opened allowing enemies of the Axis to escape. He also put Radio-Tunis out of commission. When German General Nehring arrived on November 17 proclaiming: "We come here to liberate Tunisia, in particular from Jewish oppression," Esteva protested and had him suppress the part about the Jews. (62) In fact on that same day Nehring, who had opened his command post in the United States consulate in Tunis which the Americans had deserted, and Dr. Rudolph Rahn, the Nazi diplomatic agent in Tunis, recommended that Esteva be relieved of the post of Resident General. Finally, Esteva arranged for false papers for the American consul and vice-consuls and their families. Germans had been landing at El Aouina airport for four days, but when Doolittle saw the German ground troops arrive on November 13, he asked for an interview with Philip, the Prefect of Police, since he and his household and staff had been completely cut off from contact with friends and unable to leave the residence. When philip came to the house at 9:15 p.m., Doolittle asked whether they were to remain prisoners and turned over to the German forces or whether the Tunisian administration would arrange for their departure. (63)

Philip promised to discuss it with Admiral Esteva and left immediately for his office. When he returned at $11: 15$ p.m., he informed Doolittle that they were to be evacuated to Algeria. At 12:45 a.m. November 14, Doolittle, his wife, 
their two Spanish servants, John Utter, two clerks, and a couple with their baby hastily left the house. All furnishings including silver and rugs were left behind. Since the Germans already occupied the nearby crossroads, the American party and their French guides took a round-about route. Once their cars were stopped by German soldiers with a medium tank but, because of the forceful intervention of Philip and the Residency officials, they were allowed to proceed. Doolittle believed that the German soldiers were unaware of who was in this caravan. Later they were once again stopped by Germans and again successfully passed the barrier. After a few miles all of the French officials except for a Monsieur Polifet left them with the parting words to hurry back and free the French from the prison which seemed inevitable. (64)

The rest of the trip to Algiers went without incident. At the border polifet left the group, informing them that General Barre intended to follow the orders he had been given to resist any westward advance of the German troops. Polifet asked Doolittle to impress upon the United Nations command that speed was crucial. He said that the Germans had landed some twenty tanks and four thousand men at Bizerte, while in Tunis there were about fifteen hundred Germans of which at least one thousand were ground staff for the aviation forces at El Aouina airfield.

At 8 a.m. On November 14 th Doolittle's party arrived at Bone and made contact with the British forces of 
commandos and parachutists and two Royal Airforce spitfire squadrons. As soon as they had told the British their story, Utter and Doolittle took the ladies of the party to Guelma, a town south of Bone, where they believed they would be safe. When they returned to Bone, they were taken to Algiers on a R.A.F. plane, "leaving in the midale of another air raid during which their plane was machine gunned and bombs were dropped on the field." (66)

In AIgiers Doolittle reported to Murphy and Consul General Felix cole and found that he was not needed. He then returned to Guelma passing through convoys of war material and troops streaming steadily eastward. At Guelma he learned from his wife that he was needed in constantine to help the British Army with the political situation. Returning to Constantine, Doolittle became semi-officially attached to the Army there for several months.

Doolittle found in Constantine a strong anti-United Nations sentiment among those in control. In contacting resistance groups, Doolittle learned that the same administration which had been appointed by the vichy authorities for the purpose of suppressing any "pro-British, pro-American or pro-de Gaulle sympathies were still in charge." (67) They were the same groups that had worked against the United Nations since the landings. The anti-German groups upon whom the United Nations had relied for their information were forced to remain undercover. These groups were becoming discouraged while the attitude of 
the local French authorities was anything but reassuring. (68)

When the local constantine newspaper received the news on November 19 that Barré would resist the Germans, the French censor forbade its publication. Only after a protest was made by the United Nations general to the French headquarters, did the article appear. Still the French censor told the editor that, when the Germans arrived, he would be the first to be hanged. (69)

The Prefect of Police of Constantine cautioned the Director of a Bank, who had expressed United Nations sympathy to his employees, against undertaking propaganda among his employees. The same Prefect had ordered the police to put down any demonstrations for the United Nations soldiers passing through Constantine on the part of the local citizens and had arrested some people who had welcomed United Natiions soldiers. While these demonstrators were later released, none of the political prisoners in jail for their ideas had been freed, and the local police continued to report unfavorably on United Nations sympathizers. A French general had stated that the French attitude should be one of neutrality to the united Nations soldiers passing through since they did not appear of sufficient strength to cope with the Germans.

Anti-United Nations sentiment was also evident when rumors were spread through the food lines that there was no meat and rations would be reduced because United Nations 
soldiers had seized everything in the market. Again the United Nations general protested to the French staff and a communiqué was put out stating that united Nations soldiers were bringing their own supplies taking nothing from local reserves. (70)

This local sabotage came from the civil administration and from the higher French military officials who were surrounded by members of the service d'ordre de la Légion, described by Doolittle as the French equivalent of the Gestapo. The S.O.L. was the active volunteer law enforcement part of the larger veterans organization, "La Légion des Combattants," started by the pétain government. Mast described it as a sort of police force supplementing the regular "more peaceful" police force. According to him, the S.O.L.'s function before the landing had been to watch and control opinions, denouncing those not conforming to the Vichy policy of collaboration. They were also to prevent all manifestations of ideas or reunions not conforming to this Vichy policy. (71) obviously many members of the S.O.L. had not switched their allegiance to the United Nations after the invasion.

Doolittle strongly recommended that these anti-united Nations elements be replaced. He thought that at least seventy-five percent of the local French population would welcome this action and "that the Arabs, passive and politically inert, would only look upon such action as a manifestation of the show of force which they 
admire." (72)

The political situation in constantine which

Doolittle did not find favorable to the United Nations cause was a reflection of the political situation as it was evolving under Darlan for all of French North Africa. While Darlan had made an important military contribution to the United Nations cause, in internal affairs he continued the Vichy form of government. As Darlan described it in an interview:

I am simply managing French interests in French Africa in the name of the prisoner chief of state. I am acting as a trustee of authority, the trustee of a national treasure. (73)

Thus an unexpected consequence of the American arrival in North Africa was the reinforcement of Pétain's "national revolution". Not only did Darlan continue Vichy policies there, he expelled from the army those that had helped the United Nations in the November 8 invasion and even went so far as to recommend to Vichy that they lose their citizenship. It was only Eisenhower's intervention that prevented this step.

Roosevelt, who was being severely criticized for the "Darlan deal" and the continuation of the Vichy regime in North Africa, was anxious to change the Vichy laws and told General Marshall that restrictions imposed by Vichy should be withdrawn including the ban against labor unions and the anti-semitic laws. Political prisoners were to be freed. First, however, Roosevelt thought it important to have 
Eisenhower's views on what effect he thought such a statement would have on the North Africans. (74) Eisenhower sent Roosevelt a detailed report that had been prepared under Darlan's orders outlining the steps his regime was taking to liberalize and reform the administration of North Africa (75), but decided against making a public statement. (76)

Another step Roosevelt proposed to Churchill to deal with the situation in North Africa was that they consider appointing an American and a Britisher with a veto power over French civil administrators. As a result Murphy was appointed as a personal representative of the President on Eisenhower's staff with the rank of minister and Harold Macmillan was named by Churchill to a corresponding position. (77) Murphy's position was in addition to his duties as chief of Civil Administration on General Eisenhower's staff.

In spite of Secretary Henry Stimson's strong objections, Roosevelt issued a directive turning over the administration of civilian affairs in North Africa to the State Department. (78) Murphy, as Civil Affairs Officer, was to coordinate with General Eisenhower's staff "since all civilian requirements are subject in the first instance to the military situation." (78) The primary objective of all civilian officials was to contribute to the successful military operations. Relations with the French authorities were to be conducted exclusively through or with the 
approval of the Civil Affairs Officer. (80)

Though the state Department had been put in charge of civilian administration, Roosevelt told Secretary cordell Hull on the telephone a couple of months after the invasion that Murphy "was not there to report to Hull but as a special appointee of his own to hande special matters on which he reported to Roosevelt direct." (81) While stimson thought this was bad administration, he said: "This was a truly Rooseveltian position." (82)

De Gaulle, though not informed in advance about the invasion, had taken the matter gracefully and showed satisfaction that Giraud had helped, but when Giraud and Darlan agreed that Giraud would have command of the military and Darlan head the civil administration, de Gaulle was furious and blamed the United states for bringing it about. De Gaulle had indicated a willingness to work with Giraud, but refused to have anything to do with Darlan.

Darlan's presence at the head of French North Africa had aroused opposition from all quarters. The strict Vichyites reproached him for having betrayed the Marshal by signing the cease fire. The Group of Five were frustrated that they had not been rewarded for having aided the United Nations, and the Gaullists considered Darlan an obstacle to the arrival of their leader in Algeria. Darlan was aware that there were several plots against him, even asking Murphy after lunch at the summer palace on December 23 what the Americans would do if one of these plots was successful. 
On the day after he asked this question, Darlan was assassinated by a twenty year old French student who was immediately condemned to death. (83)

only recently has it been learned that it was the British Special Operations Executive (S.O.E.) that armed the assassin. (84) Because the assassin had been a student of Carleton Coon, who during the month of December had been an instructor of the de Gaullist Free Corps of Africa near Algiers, Eddy thought it was a good idea for coon to disappear for a while. One of the places coon went was "through the cold and night to constantine where [he] found Hooker in a cold room with his wife Vecka, two Basque maids and two Pekingese dogs in attendance." (85)

The assassination of Darlan "ended one problem" as Eisenhower commented to his Aide, Butcher, "but no doubt created many more." (86) One of the problems created by Darlan's murder was that Giraud, now head of both civil and military affairs, placed a reactionary Vichy general in charge of investigating the death of Darlan and this general used his post to persecute the leaders of the Algiers Gaulist underground. Coon reported that though the assassin was a Royalist, the authorities rounded up Free French and others whom they wished to harass. Several of the instructors where he taught were arrested. (87) Giraud brought members of the Group of Five into the administration. Lemaigre-Dubreuil, though not taking a cabinet post, became his political adviser. Giraud, whose 
primary concern was military victory, would soon prove to be a weak leader. A political conservative, he would wait until the spring of 1943 to change the Vichy laws and then only under pressure.

According to Vice-Consul Kenneth Pendar, the men Giraud chose to administer, "were hardly outstanding leaders or in any way representative ones." (88) Pendar said: "We used them because they were available. Later we continued to use them because we were committed to them." Pendar thought Giraud was honest but inept and was too slow in restoring Vichy destroyed civil liberties, in giving the Jewish people civil rights and in getting rid of the vichy group in North Africa. While Giraud was not in favor of Vichy's ideas, he thought everything could wait until the war was won. (90) Harold Macmillan, the British political adviser to Eisenhower, wrote in hindsight that it would have been better if Murphy had been withdrawn at the beginning of January 1943 when the invasion had occurred and Darlan's assassination had allowed Giraud's natural succession to power. He believed a new phase was about to begin between France and the different French groups and the United Nations. Murphy had been employed in a Fifth Column operation. His job had been to make contacts and to organize plots to prepare for a military landing. He had had to deal with reputable as well as some questionable people such as Darlan and many disreputable agents. Macmillan thought he was handicapped by this in the new phase of his work because 
he was under obligations to a lot of people. According to Macmillan Murphy should have been replaced by somebody uncommitted. (91)

It is possible to view Macmillan's statement as an example of British bias. The British were, after all, committed to de Gaulle for whom Giraud, backed by Murphy, was simply an obstacle. The United States, on the other hand was committed to that obstacle, Giraud. Biased as Macmillan may have been, Giraud would not prove to be a good choice. 
NOTES

CHAPTER V

1. Churchill, The Hinge of Fate, 542.

2. Alfred D. Chandler, ed., The Papers of Dwight David Eisenhower ( 5 vols., Baltimore: Johns Hopkins Press, 1970), I, 525. Hereafter cited Eisenhower Papers.

3. Ibid.

4. Ibia.

5. William D. Leahy, I Was There (New York: Whittlesey House, 1950), 7 .

6. Mark W. Clark, Calculated Risk (New York: Harper, $1950), 54$.

7. Dwight Eisenhower, Crusade in Europe (Garden City, New York: Garden City Books, 1948), 83-34.

8. Churchill, Hinge of Fate, 538.

9. Harry C. Butcher, USNR, My Three Years with Eisenhower (New York: Simon and Schuster, 1946), 115.

10. FRUS 1942 II, 297. 148.

11. Donovan to Roosevelt, May 11, 1942, PSF 166, No.

12. Butcher, My Three Years with Eisenhower, 108.

13. FRUS 1942 II, 189.

14. Leahy, I Was There, 74 .

15. Donovan to Roosevelt, April 21, 1942, PSF 165, No. 435 .

16. FRUS 1942 II, 394.

17. Murphy, Diplomat Among Warriors, 118. 
18. FRUS 1942 II, 396.

19. Eisenhower Papers, I, 636.

20. FRUS 1942 II, 396.

21. Ibid, 395.

22. Ibid, 396.

23. Eisenhower Papers, I, 637.

24. Ibid, 640 .

25. Ibid, 639 .

26. Ibid.

27. FRUS 1942 II, 409 .

28. Ibid, 346 .

29. Murphy, Diplomat Among Warriors, 105.

30. Hull, Memoirs, II, 1191.

31. FRUS 1941 II, 410 .

32. Robert E. Sherwood, Roosevelt and Hopkins, An Intimate History (New York: Harper and Brothers, 1948), 644.

33. Churchill, Hinge of Fate, 608.

34. Eisenhower Papers, 615.

35. Elliot Roosevelt, ed., F. D. R.: His Personal Letters 1928-1945 (4 vols., New York: Duell, Sloan and Pearce, 1947-50), II, 1362 .

36. Eisenhower Papers, 672.

37. Eisenhower, Crusade in Europe, 78-83.

38. Arthur L. Funk, The Politics of Torch: The Allied Landing and the Algiers Putsch, 1942 (Lawrence: University Press of Kansas, 1974), 123.

39. Charles Mast, Histoire d'une Rébellion: Alger 8 Novembre 1942 (Paris: n.p. 1969), 206.

40. Churchill, Hinge of Fate, 621.

41. Murphy, Diplomat Among Warriors, 138. 
42. Eisenhower, Crusade in Europe, 107.

43. Kenneth Pendar, Adventures in Diplomacy (New York: Dodd Mead and Company, 19451, 102.

44. Eisenhower, Crusade in Europe, 108.

45. Eisenhower Papers, 707.

46. Samuel I. Rosenman, ed., The Public Papers and Addresses of Frankl in D. Roosevelt (13 vols., New York: Harper, 1938-1950), XI, 479.

47. Ibid, 480 .

48. Ibid.

49. Butcher, My Three Years with Eisenhower, 206.

50. "De la Campagne de Tunisie," La Dépêche Tunisienne, June 7, 1960. In the possession of Katya Coon, Marshfield, Massachusetts. Hereafter cited Katya Coon.

51. Albert Kammerer, Du Débarquement Africain au Meutre de Darlan (Paris: Flammarion, 1949), 322.

52. Ibid.

53. Doolittle to Hull, June 2, 1943, 8515.00/256.

54. Ibid.

55. Ibid.

56. Ibid.

57. "De la Campagne de Tunisie", June 7, 1960.

58. Mast, Histoire d'une Rébellion, 377.

59. "De la Campagne de Tunisie", June 7, 1960.

60. Kammerer, Du Débarquement Africain au Meutre de Darlan, 362 .

61. Ibid.

62. "De la Campagne de Tunisie", June 7, 1960.

63. Doolittle to Hull, November 23, 1942, Katya Coon. 64. Ibia. 
65. Ibid.

66. Ibid.

67. Ibid.

68. Ibid.

69. Ibid.

70. Ibid.

71. Mast, Histoire d'une Rébellion, 71.

72. Doolittle to Hull, November 23, 1942, Katya Coon.

73. Quoted in Langer, Our Vichy Gamble, Broadcast by Radio Moroc, December 24, 1942, 379.

74. Eisenhower Papers, 817.

75. Ibid.

76. Ibid, 821 .

77. Langer, Our Vichy Gamble, 378 .

78. Stimson Diary, No. 8, February 11, 1943, Yale University.

79. FRUS 1942 II, 473.

80. Ibid, 478 .

81. Stimson Diary, No. 8, February 1, 1943.

82. Ibid.

83. Laffont, Histoire de la France en Algérie, 345.

84. Douglas Dodds-Parker, Setting Europe Ablaze: Some Account of Ungentlemanly Warfare Windlesham, Surrey:

Springwood Books, 1984), 115.

85. Carleton Coon, Adventures and Discoveries: The Autobiography of Carleton S. Coon, Anthropologist and Explorer (Englewood, New Jersey: Prentice Hall, 1981), 174.

86. Butcher, My Three Years with Eisenhower, 229.

87. Coon, Adventures and Discoveries, 174.

88. Pendar, Adventures in Diplomacy, 121. 
89. Ibid.

90. Ibid, 130 .

91. Harold Macmillan, The Blast of War 1939-1945 (London: Harper and Row, 1967), 189-190. 
CHAPTER VI

DE GAULLE-GIRAUD CONFLICT

By November 1942 the United Nations had seized the initiative in North Africa. In the west they had successfully invaded Morocco and Algeria while in the east the British had taken El Alamein pushing the Germans back into Libya. Although fighting continued in Tunisia, Roosevelt thought the Germans would soon be driven out and proposed to Churchill that the miliary chiefs, including the Russians, meet to discuss the follow up to the Tunisian campaign. Churchill wanted instead a Big Three meeting. He feared that at such a meeting the Russians would argue for a cross channel invasion in 1943. In order to dissuade the Russians from this idea, he thought that he and Roosevelt needed to handle the matter with stalin rather than leaving it to the military chiefs.

Instead of a cross channel attack in 1943 churchill was promoting the idea of an attack across the Mediterranean once the Tunisian campaign had eliminated the Axis from North Africa. He suggested striking at Sardinia or Sicily, "at the soft underbelly of the Axis." (1) In spite of General Marshall's warning against too many diversionary operations, Roosevelt and the American chiefs were also 
inclined toward the Mediterranean plan knowing that not enough American troops would be available for a 1943 assault on Northern Europe.

Churchill believed that at a Big Three meeting he and Roosevelt could explain in person to stalin their reasons for postponing the cross channel invasion in favor of the Mediterranean plan. Churchill suggested that they meet in Iceland, but Roosevelt preferred a warmer place and proposed Africa. Roosevelt sent a cable to stalin suggesting the three leaders meet in January to make strategic plans, but Stalin declined the invitation claiming he was needed in the Soviet Union where a major offensive was being waged at Stalingrad. Roosevelt and Churchill suspected the real reason was that he feared that the two Anglo-Saxon leaders would try to persuade him that a second front was not feasible in 1943.

In spite of Stalin's decision not to attend the meeting, Roosevelt wanted to proceed with it anyway. Not only would it be an opportunity to plan the follow up to the North African campaign, but it would give a chance to discuss postwar plans, now that a turning point seemed to have been reached in the war. During the fall of 1942 FDR had been considering postwar objectives. He believed the Axis powers would need to be disarmed and forced to renounce their ideology. To make sure of this Roosevelt wanted their unconditional surrender. He had still another reason just now for wanting to announce this doctrine. The Darlan deal 
had raised fears with stalin and others that the western powers would negotiate an early peace with collaborators or with Axis leaders. The announcement of the doctrine of unconditional surrender would lay those concerns to rest. In particular, it should reassure stalin. While Roosevelt did announce the doctrine of unconditional surrender at the conference, which took place at Casablanca from January 14-24, discussion of the doctrine showed differences of opinion between the President and his Secretary of State. Hull was afraid that it might prolong the war if the people of the Axis countries thought they had nothing to which to look forward. He also thought the doctrine would require that the Americans and British be prepared to take over the governments of the conquered countries. (2) The fact that Hull was opposed to the idea was probably one reason that Roosevelt did not have him come to the conference. But Hull had really been left out of French matters ever since st. Pierre and Miquelon. Because of Hull's intense anger at de Gaulle for ordering the Free French take over of those islands, Roosevelt had taken French matters into his own hands. Instead the President, who liked being his own secretary of state, delegated to Hull and the state Department the job of planning for the postwar peace keeping organization.

Another reason Roosevelt did not want Hull at the conference may have been his fear of Hull's antagonism toward de Gaulle, whom he expected to meet. Roosevelt hoped 
to find a solution to the problem that followed Darlan's death of both the Giraud and de Gaulle factions wanting to be recognized as the provisional government of France - "the French quagmire", as he called it. (3) At the conference the Combined Chiefs of Staff decided in only four days that, once the Germans had been cleared out of North Africa, Sicily would be the next target, but the French problem proved to be more difficult.

Upon the assassination of Darlan, de Gaulle had drawn up a program to meet the new situation whereby his committee would move to Algiers and become the provisional government of the liberated French with himself as president. Giraud would be designated as commander-in-chief of all the French armed forces fighting with the United Nations. (4)

The Giraud group had a similar plan: Giraud with his advisors would be the civil head and de Gaulle would be a member of the Vichy created Council of the Empire, and a military adviser. From the beginning of their association with the Americans, the Lemaigre-Dubreuil group had hoped to set up an autonomous French government in North Africa. While they said their first goal was a military one, they had a political plan as well. They considered that these political aims had been endorsed by the United States in the Giraud-Murphy Accord of November 2, 1942. This accord, based on several letters between Giraud and Murphy, guaranteed

that the restoration of France to full 
independence in all the greatness and vastness which it possessed before the war in Europe as well as overseas is one of the war aims of the United Nations. (5)

Furthermore, the United States promised to treat the French as allies and declared that they would not involve themselves in interior administrative questions of the temporarily occupied territories.

This accord had been annulled to a certain extent by the Clark-Darlan Treaty, by which the administration of North Africa was left to the French under Darlan in exchange for their help with the war. Now that Darlan was out of the picture, Lemaigre-Dubreuil tried to reestablish the terms of the Giraud-Murphy Accord. When Lemaigre-Dubreuil visited Washington at the end of December 1942 to make arrangements for the rearming of the French, Hull agreed to see him. Lemaigre-Dubreuil was astonished to find that Hull knew nothing of the Giraud-Murphy Accord. Once Hull knew of the accord, Lemaigre-Dubreuil tried to get him to agree to its consequences: namely the formation of a provisional government in Algeria allowing France, independent of the Axis, to be represented abroad. Hull replied that, if the Giraud group tried to form such a government, the Foreign Office would insist on making de Gaulle its head. Hull did not think it was the right time to raise the political problem. (6)

Informed by Hull about his talk with Lemaigre-Dubreuil and the Giraud-Murphy Accord, Roosevelt, just before his departure for Casablanca, tolä the Joint Chiefs of Staff at 
a meeting on January 7, 1943 that Murphy, in giving certain pledges to restore France and the colonial possessions, "had exceeded his authority," (7) and that he, as President, was not prepared to make any promises. There were some colonial possessions that would not be returned to France, and he wanted the Chiefs of Staff to make this clear to Murphy and Eisenhower at Casablanca.

Like Hull, Roosevelt wanted to make no promises to recognise either faction as a provisional government. Instead he wanted to make temporary arrangements with local authorities as territories were liberated. He felt strongly that the French people should choose their own government after the war.

Murphy and Macmillan had suggested that de Gaulle be offered joint political control with Giraud. The latter agreed, but de Gaulle resisted. In fact, de Gaulle refused to come to the conference at all. His committee did not wish to have any part of a government including Vichy personnel such as General Auguste Nogùes. Roosevelt wired Anthony Eden in London, "I have got the bridegroom, where is the bride?" (9) Only when Churchill threatened to cut off financial support, did de Gaulle agree to appear.

It didn't help matters when Giraud met de Gaulle as though he were still the lower ranking officer who commanded a regiment of tanks. He had not taken account of the fact that he was now a powerful political force respected by members of the Resistance. (10) De Gaulle refused to 
support the Murphy-Macmillan plan claiming it was dictated by the Americans and British, but did agree to have his photograph taken shaking hands with Giraud.

It may have been because of his annoyance at de Gaulle that Roosevelt signed two memos presented to him by Giraud just before he left the conference and after churchill had already gone. These memos, which came to be known as the Anfa agreement after the suburb of Casablanca where the conference was held, were drawn up by Lemaigre-Dubreuil.

Lemaigre-Dubreuil, who questioned Giraud's ability to look out for his group's political interests, had managed to be at casablanca by saying that he had to visit family in Morocco. Later Murphy would accuse Lemaigre-Dubreuil of lying to get to Casablanca. By signing these two memos, the President agreed to provide weapons and supplies to Giraud's forces in North Africa and to recognize Giraud as the military-civil commander in Africa. (11) Roosevelt also agreed that the letters exchanged between Murphy and Giraud before the meeting remained in force. By these letters, the United states had guaranteed the restoration of the French Empire and to treat France as an ally. Probably Roosevelt did not realize what he had signed because, in agreeing to the latter, he was doing what he had told the Joint chiefs he opposed.

In the political field Roosevelt had only recognized Giraud as the trustee of French interests, not as the head 
of a provisional government. Nevertheless, Churchill, on learning of the agreement which had committed Great Britain to Giraud as well, insisted on amending it to include de Gaulle and to changing the word trustee to manager of French interests. Because of Giraud's indifference to politics, he agreed to Churchill's changes, thereby losing the political benefits of Anfa. (12)

Basic differences about the nature of the post-war world between the British and Americans underlay the de Gaulle-Giraud problem. Churchill wanted a strong France that would counterbalance Russian hegemony in central Europe. Roosevelt and Hull wanted a collective security agreement that would enable the major powers to deal individually with the trouble spots. Nor did Roosevelt see France as one of these great powers. In a talk with Molotov eight months before, Roosevelt had included France as one of those countries that should be disarmed after the war. When Molotov asked about France becoming a great power, Roosevelt said it might happen in ten or twenty years. (13)

It was at the Casablanca Conference that these different strands of Roosevelt's thinking on collective security began to fit together. While there Roosevelt discussed with his son, Elliot, his idea of trusteeship which would replace the old mandate system of the League of Nations. The trustees would report to the "organization of the United Nations." (14) This was the first time Elliot had heard of this plan. Indochina was one of the countries that 
Roosevelt had in mind for a trusteeship and he was to propose this to Anthony Eden later in the spring of 1943. When Eden objected, an impasse developed with the British over colonialism in Southeast Asia.

Differences with the British over colonialism were quite apparent at Casablanca. The trip to North Africa had reinforced Roosevelt's anti-imperialism. On his way he had visited Gambia where he was shocked by conditions.

Dirt. Disease. Very high mortality rate. I asked, life expectancy - You'd never guess what it is. Twenty-six years. Those people are treated worse than the livestock. Their cattle live longer. (15)

On returning to the united States he "talked much about the horrible conditions of the natives in the places he had stopped." (16)

At a dinner party for the Sultan of Morocco, Roosevelt, in front of Nogues and Churchill, expressed his sympathy for colonial aspirations for independence and suggested some form of economic cooperation between Morocco and the United States after the war. While this raised the hopes of North African nationalists, it only accentuated the differences with Churchill.

Roosevelt's attitude could only cause problems with all the French. The Giraud group were no less imperialminded than the Free French of de Gaulle. Roosevelt probably perceived Giraud as being primarily concerned about military matters and somebody that he could control in the political realm. At all costs he wanted to avoid reinforcing 
Churchill's imperial ideas by recognizing his protégé, de Gaulle.

While the United States was committing itself to the support of Giraud at Casablanca, disillusionment with him was already evident among his supporters. Discouraged by Giraud's weakness, Lemaigre-Dubreuil had not accepted any position in his administration, becoming instead his political adviser. Lemaigre-Dubreuil complained that instead of a total rupture with Vichy, the new situation left pétain in a certain sentimental place as "prisoner" of the Germans and the Vichy collaborators still in place. (17)

General Mast had good reason to be disillusioned. Mast, who had been Giraud's representative in North Africa before the invasion, expressed real bitterness about the way Giraud refused to intervene when Darlan expelled Mast and the other officers, who had helped with the United Nations invasion, from the army "even though" as Mast wrote, "the most elementary moral sense would have dictated to him to oppose it with energy." (18)

Nor did Giraud intervene when Darlan had Vichy strip Mast and the others of their French citizenship. Only because Mast went to Eisenhower, who intervened with Darlan, was their citizenship restored. According to Mast, Giraud on the civilian front was obviously not a chief - "one who takes responsibility and covers his subordinates for the consequences of the mission he had given them." (19) Since Mast and the others had lost their army positions, Giraud 
decided to group them in a liaison mission to the united Nations forces under Mast's command. They were installed in a few rooms in the St. George's Hotel in Algiers where the United Nations forces had their headquarters. (20)

Other officers, who had helped the United states before the invasion, were not as lucky as Mast and his group. There was a program of removing those officers and sending them to remote posts where chance of contact with Americans was slim. One of the best French regiments which had tried to prevent Noguès from resisting the American landing had been practically disbanded. (21)

In his position as head of the liaison mission to the United Nations forces, Mast was able to observe Eisenhower's conduct of the war. This campaign was not proceeding as swiftly as had been anticipated. The strategic plan formulated before the disembarkment was for the First British Army under General Kenneth Anderson to clean out the Axis troops from Tunisia. Once this was accomplished, he was to go to southern Tunisia and fight Rommel whose army was being pursued by the British Eighth Army coming from Libya. Difficulties with supplies, heavy rains, and deep mud in the northern part of Tunisia had stopped Anderson's advance in December. The Germans, who had poured troops into the Bizerte-Tunis area, began a counterattack which put the United Nations forces on the defensive. Observing the troops mired down in the mud in early December, Eisenhower decided to halt operations on a line in Tunisia running from Medjez- 
el-Bab in the north to Gafsa in the south. This line was held by British troops in the north, French (African Army) in the center, and American in the south.

While the offensive from the west temporarily halted, that from the east by the British Eighth Army was advancing westward in Libya and on February 2 crossed the Tunisian border. Concerned about his position, Rommel began a series of attacks on his western front in February causing bitter fighting, but by March United Nations counterattacks forced the Germans to begin falling back. Soon the attack from two fronts was successful, and on May 7 American and French troops took Bizerte while the British at approximately the same time entered Tunis. Though several more days were required for mopping up and for collecting the prisoners, this was the real end of the Tunisian battle.

Mast believed that victory could have come by the end of December if the Americans had reinforced Anderson's two British brigades. Unfortunately a powerful German army supported by airplanes from sicily could not be beaten by only two British brigades. (22) Instead of committing more of their troops to battle, according to Mast, the American command was preoccupied with training their troops behind the combat zone while others were protecting the rear in Morocco in case of a German invasion through spain. Mast found that there was no United Nations strategic plan to combat a classic German strategy which had been well thought out. Mast blamed this on Eisenhower's lack of 
experience. (23) He was struck by the fact that, even though the United Nations had numerical superiority, the troops committed to battle were always less than what the Germans had and for this reason could not impose their will. (24)

Mast was also critical of the Americans for not rearming the French as they had promised at the meeting that he had had with Mark Clark at Cherchel. While the French African Army had fought well, they could have done better with proper arms. From Constantine in January Doolittle confirmed what Mast said about the French forces in southern Tunisia being badly armed. They were armed with old material, and what modern weapons they possessed were short of ammunition. Their losses had already been heavy. Doolittle thought

if the elite French troops now there should receive a beating for lack of equipment, food, and services the morale of the French army, none too good except in the isolated units and individuals, may also receive a blow which will permanently render French assistance useless. It is to be hoped that the Allied command will make use of their knowledge of the ground and local tactics instead of letting this happen. (25)

Doolittle was also concerned because the Germans were giving the Tunisians in the Axis occupied area of Tunisia goods that had been pillaged locally and were reported to be arming Tunisian snipers in northern Tunisia. However, he had learned that plans were under way to counteract this by buying those Tunisians back with foodstuffs and clothing. (26) 
Not only was there the French African Army of 150,000 men under Giraud fighting in North Africa, but there were the de Gaulle Free French forces of 15,000 fighting. One Free French division under Le Clerc had come north to Tunisia from Chad while another under Larminat was fighting with the British Eighth in Libya. Rivalry existed between the French African Army and the Free French forces each of which tried to recruit from the other. This was one of the reasons Churchill and Roosevelt were trying to bring the factions together. Mast had the opportunity to compare the morale of these two forces when in February he was offered a new mission.

When General Georges Catroux came to North Africa as liaison between the de Gaulle and Giraud groups, Mast explained to Catroux how Giraud, frightened by his illegal position, sought always to get back into what he believed to be legality. This obsession, Mast observed, had eliminated all those officers responsible for the rebellion and without whom Giraud would not have become the leader. (27) Now that Giraud had been named civil and military commander-in-chief by the Council of the Empire, he signed all his decisions in the name of the "Marechal empeché." Mast explained to Catroux the heartbreaking situation of all the officers abandoned by their chief and for this reason put in quarantine by the rest of the army. While catroux could not intervene, he proposed to Mast to come as a liaison to the Free French forces in Egypt and Lebanon. Giraud agreed to 
let Mast go on this new assignment. (28)

Mast had no sooner assumed his new job than an incident occurred that made him aware of its importance. A young French soldier appeared in Algiers in a torn shirt. This soldier, who was fighting with the de Gaulle forces in southern Tunisia, had been allowed to leave his unit to visit his family in Algiers only to find himself badly treated in an encounter with soldiers belonging to Giraud's French African Army. (29)

When Mast visited the First Free French Division of General Larminat, he discoverd a far better morale among the soldiers than that of the soldiers of the French African Army who were jealous of each other, disputed among themselves, and among whom defeatism was prevalent. The defeatism among the latter was so strong that, at the time of Rommel's attack in southern Tunisia, a French colonel had been impatient for the Germans to arrive at Constantine. Mast believed that the defeatism of Vichy had left its mark on these men and they were afraid to show their patriotism. Because of Catroux's intervention, Mast would later be appointed as Resident General of Tunisia. Giraud had wanted somebody else, but Catroux had said it was important to choose somebody who had never accepted the principles of Vichy's National Revolution. (30) A broken hip, resulting from an airplane accident in Lebanon, would keep Mast from assuming his post at the time of the Tunisian victory. General Alphonse Juin served as acting Resident General 
until he had recuperated.

In Washington Secretary of War Stimson considered winning in Tunisia a significant step in the war. In his diary on May 12, 1943, he wrote, "Today is a great day of victory for the allied arms in Tunisia." (31) His press conference was a "jubilant occasion because of the victory," (32) over 150,000 prisoners had been taken. He told the press that

the defeat of the Axis in Tunisia was more than the loss of an army - it was the loss of a campaign, the loss of a continent. The battle of Tunisia ranks with the battle of Stalingrad as one of the two great military disasters suffered by the Germans within a few months. (33)

At the same time as stimson was celebrating the military victory in Tunisia, Cordell Hull was proclaiming it a victory for the Vichy policy. Talking with Churchill, who was in Washington, Hull said, "Your' and our Vichy policy has been justified and vindicated 100 per cent." (34) Hull had been sensitive to the criticism of this policy as well as the constant press attacks. It would be only two months later in July 1943 that Hull requested from Stimson access to material for a book that he was having written on the Vichy policy by william Langer (Our Vichy Gamble).

While Churchill was in Washington, he discussed the Giraud-de Gaulle problem. Progress had been made since the Casablanca conference in bringing the two factions together. This was partly due to the efforts of Jean Monnet, a French businessman who had originally gone to Washington to work 
with the British Purchasing Commission. He was highly regarded by Harry Hopkins who persuaded Roosevelt to send him to North Africa to work with Giraud on handling the Lend Lease supplies for equipping the French Army. (35) According to Robert Sherwood, this was one time when Hopkins successfully circumvented the state Department. Hull had not wanted Monnet to be sent, believing him too closely connected with the Lazard Freres banking firm which had ties to the de Gaulle organization in London. (36)

As soon as Monnet arrived in Algiers, he realized that changes were needed. He persuaded Giraud to do away with the vichy laws and to institute more democratic ones. On March 5 in a radio address Giraud announced that "France had no racial prejudices." (37) Then on March 14 Giraud made a speech advocating that all Frenchmen fighting the Axis should unite meaning, of course, the French African Army and the Free French forces. He also advocated the return to a more democratic regime. On the eighteenth he had ordinances published restoring the laws of the French Republic and abrogating those imposed on North Africa by the Vichy government, while letting it be known that he was ready to receive General de Gaulle in order to form a union. (38) Commenting on Giraud's speech of the fourteenth, Doolittle, who had been temporarily assigned to Rabat, Morocco in February, said the French there were unanimously in favor, and the bulk of the population approved of the ordinances. They had traditionally been left-wing 
republicans and had favored de Gaulle. Almost all Frenchmen wanted to see the independence of France restored.

There was, however, a minority opposed to the ordinances. Among those opposed were high ranking government officials, army and navy officers, and former leaders of the Legion. These officials and officers were worried that they might be called to account under a more democratic regime for their actions since 1940. Some were simply reactionary. This minority considered "the maintenance or installation of a 'strong' government as important as the defeat of Germany." (39) Doolittle thought this group might have been used by pro-Germans such as Laval, but any pro-German activity they engaged in was only ircidental to their main purpose of building a "strong" government. They adapted easily to the situation created by the United Nations landing up to the point where it was important to revise internal policy. According to Doolittle:

Here they were incapable of flexibility. On the contrary they resorted to every device to prevent public opinion from expressing itself and to retard the inevitable. (40)

Nogues was still one of the primary obstacles to the union Giraud was now proposing to de Gaulle. Doolittle had had an opportunity to talk to Nogués in person. He described him as having a "flexible" character which had made him more susceptible to orders from Vichy than Esteva, whom he described as the "inflexible 'Bearded Virgin' of Tunis, who when pushed too far, flew to Vichy, pounded on tables and flatly refused the more outrageous requirements." 
Removing Nogues would do a great deal to elevate the moral tone of all of Morocco. (42) Doolittle, who had had the opportunity to know Nogues and Esteva, both of whom had followed Vichy at the time of the invasion, seemed to have retained more respect for Esteva than Noguès.

While de Gaulle let Giraud know he had received his message with pleasure and that he hoped to go to North Africa soon, it required two more months of negotiations before de Gaulle actually left London for Algiers. Finally he arrived in late May and on June 3 Giraud and de Gaulle announced formation of the French Committee of National Liberation on which the two would share the presidency. A contributing factor to the union may have been the evident popularity of the de Gaullists both in North Africa and in mainland France. The Germans' total occupation of France and the drafting of French workers starting in February 1943 for work in Germany had caused many French to look toward de Gaulle as the main hope of deliverance from the Axis. The various Resistance movements had pulled together into a National Council of the Resistance under Jean Moulin and announced that they considered de Gaulle their leader on May 15. (43)

Hull and Roosevelt decided to accept the French Committee of National Liberation because it had promised it would turn over its power to the Provisional French Government to be established after liberation. (44) Roosevelt had insisted that Giraud keep command of 
the army and since Churchill agreed with this, Giraud remained as commander-in-chief.

The fusion of the de Gaulle-Giraud factions did not stop the problems nor did it ease the annoyance of Roosevelt and Hull with de Gaulle. Hull expressed his bias against de Gaulle in the lack of recognition given to the military achievements of the de Gaulists in North Africa. Though these were considerable with much loss of life among the Free French, Hull in a memo to the President which he quoted in his "Memoirs" said:

It cannot but be realized from your message of congratulations for the Allied victory in North Africa that the real French contribution was given by the French forces under General Giraud, while throughout the period of the battle de Gaulle, through his political agitation directed from London, caused nothing but disturbance and concern to our military commanders. (45)

In his determination to justify the Vichy policy, Hull discredited the Free French divisions even though they deserved praise. (46)

In spite of the union, problems continued in North Africa. One problem was that each army continued to recruit soldiers from the other. In Tunisia the Free French troops who had come from chad under Leclerc and those who had been fighting with the English Eighth under Larminat had been welcomed with enthusiasm. (47) After the victory parade in Tunis a fight for recruitment began between the two forces. Recruiting bureaus were set up. Since the Free French troops had new and modern uniforms, they were at an advantage. 
Entire units of Giraud's African French troops rallied to the Free French. Another reason for the success of the recruiting offices opened by the de Gaulle forces in Tunisian towns under Generals Leclerc and de Larminat was explained at some length by Doolittle after he returned to Tunisia. Before the November 8 landing, Tunisia had been the most favorably inclined toward the United Nations cause of any of the North African countries. This was because of the menace of an Italian takeover. Tunisia's rather small French population was equalled by Italians, and there was an active Italian Armistice Commission resident in Tunisia. In some respects Tunisia was like an occupied territory. These conditions as well as the closeness to the fighting in Tripolitania caused the spirits of the French to go up as the British armies moved westward and those of the Italians to go up as the fighting moved eastward. With the last big advance by Rommel, the French realized the danger in which they stood. (48)

Before November 8 , with the exception of a few officials who worked for Vichy, according to Doolittle, the feelings were almost entirely for de Gaulle as Giraud had not appeared on the scene. Doolittle may have been expressing a selective perception here since he had mainly talked to Resistance French. Other French who lived in Tunisia at the time recall that petain enjoyed substantial support among the colonists until the invasion. After that de Gaulle being better known through the radio was favored 
over Giraud. During the Axis occupation the spirit of resistance was so pronounced that the Vichy regime was required to send over from France "special strong arm squads" to replace the heads of the Legion and other pro-Vichy organizations. Only a few French Tunisians were found ready to persecute their fellow Frenchmen. (49)

After the invasion most of the French residents of Tunisia, knowing that Giraud was leading the North African French forces, assumed that this was simply a part of the whole and that the union between Giraud and de Gaulle would be arrived at quickly. Reports of dissension between the two men, which appeared in the German controlled press and over the radio, were considered as so much propaganda. When the United Nations forces arrived and Tunis was retaken, the inhabitants were surprised to learn that the dissension was true. The surprise turned to wonder and finally to annoyance. It was in this context that the de Gaulle recruiting was successful. (50)

When de Gaulle visited Tunis in late June, he expressed some of his feelings about the American attitude toward him. On his arrival he had received an enthusiastic reception. At a dinner in his honor Doolittle asked him how he had liked the reception given him by the Tunis crowd.

The General drew himself up to his full height, which is a great deal, and stated that it was to be expected because there was no doubt of the sentiment of the majority of Frenchmen in regaxd to the Free French Movement, sentiment which was unfortunately ignored by representatives of certain governments for political reasons. (51) 
When Doolittle asked him about this remark, de Gaulle explained he was referring to the representatives of the American government who, while declaring for the unity of the French people, were rendering that unity impossible by not permitting the necessary changes which would produce such unity. "For instance, he said, the creation of this half-and-half committee at Algiers . . was directly due to American intervention." (52)

After dinner, while coffee was being served, de Gaulle came up to Doolittle and asked him to sit and talk with him. The General praised the United States action in North Africa, but said that the Americans had overlooked one thing,

the sentiment of the French people underlying the group of big colonists, industrialists, and military figures with whom the Americans had dealt and who had introduced the figure of General Giraud. (53)

Giraud, he considered "a fine soldier, a courageous patriot, and altogether a splendid person," (54) but at that time there were only two possible "mysticisms or loyalties, that of Vichy and Marshal pétain, who stood for defeat, and that of the Free French, who had always stood for resistance and resurrection of France." (55) He explained to Doolittle that the Americans should not have been surprised at the coolness of Giraud's reception in North Africa since he stood for neither or both at the same time and could not possibly have any political influence. Too many people with the Vichy spirit surrounded General Giraud and the small people who 
represented the other side had not been given the voice they deserved. (56)

De Gaulle complained to Doolittle about American

newspaper attacks which

$$
\begin{aligned}
& \text { accused him of being } 1 \text {. a fascist and } \\
& \text { reactionary } 2 \text {. a communist } 3 \text {. desirous of } \\
& \text { bringing back the old French parliamentary } \\
& \text { machine with all its faults and } 4 \text { personally } \\
& \text { ambitious to emulate Hitler himself. (57) }
\end{aligned}
$$

All of these were false, he said, and he wondered why the American press was so poorly informed on the objectives of his movement. (58)

In this, his first meeting with de Gaulle, Doolittle

was

$$
\begin{aligned}
& \text { greatly impressed. . With his evident } \\
& \text { sincerity and directness. De Gaulle is } \\
& \text { obviously fanatic, a man with a single } \\
& \text { idea, but there is no doubt of his hold } \\
& \text { on the rank and file of the French people, } \\
& \text { or even in the lower ranks of the French } \\
& \text { North African Army which has rapidy } \\
& \text { gravitated in the direction of the Free } \\
& \text { French Forces wherever there has been } \\
& \text { contact between the two groups. (59) }
\end{aligned}
$$

Doolittle thought de Gaulle's visit had "infused new life into the de Gaulle movement in Tunisia," (60) but, because of the withdrawal of almost all the Free French forces to Tripoli with the British Eighth Army, recruiting had fallen off.

While the rivalry between the two factions over recruitment may have lessened, that between the two leaders on the Committee continued. Differences between them were so bad that in September Murphy told the state Department that 
it threatened the prosecution of the war. Just as Giraud was losing his troops to the de Gaulle forces, so was he losing ground to de Gaulle in the political field. Harold Macmillan made an interesting observation about Giraud in his War Diaries. After calling on him in late June he wrote:

The old boy was as charming and as vague as ever. I like him more and more, but of course he is really out of his depth. (61)

No doubt it was because Giraud was "out of his depth" that de Gaulle would be able by November to force him out of the FCNL though he still retained the title of commander-inchief of the French armies. Macmillan talked to de Gaulle the night Giraud left the Committee in November and had this to say about de Gaulle.

Once again I ended the day feeling that de Gaulle stood head and shoulders above all his colleagues in the breadth of his conception for the long term. Meanwhile, he was clearly the victor in the short-term struggle for power. Giraud, while remaining for the time being Commander-in-Chief, left the Committee. (62)

While the power struggle between de Gaulle and Giraud that Roosevelt and Churchill had tried to resolve at Casablanca had finally been settled, the Committee still struggled to get Roosevelt to recognize them as the provisional government. Churchill had brought up recognition when he had been in Washington in May, and then in July he had sent Roosevelt a wire urging him to recognize the Committee. According to Macmillan,

he did seven drafts of it before sending it. It is witty, convincing, pleading - loyal all at once. I feel it must have an effect. (63) 
It had no effect on Roosevelt nor did a wire from Eisenhower who also wanted immediate recognition of the committee.

Roosevelt was determined that the French people should choose their own government after the war. De Gaulle's ousting Giraud from the Committee simply increased Roosevelt's antagonism toward de Gaulle and his determination not to recognise the committee. He feared that, by doing so, he would be endorsing him as the postwar head of the French government. Now more concerned than ever about what he perceived as de Gaulle's dictatorial tendencies, he was afraid de Gaulle would not give the French people a chance to choose their own goverment after the Germans were expelled and his leadership would cause civil war in France. It would not be until October 1944 that Roosevelt finally agreed to granting recogniton. Macmillan contended that by snubbing de Gaulle, the Americans elevated him in French eyes.

Furthermore, the Americans in backing Giraud had backed a general with very old fashioned, right-wing ideas, one of whose main concerns had been reestablishing his own "legitimacy" with vichy. He was obviously out of step with the mainstream of French political opinion.

One can only wonder at Robert Murphy's inability to perceive Giraud's political limitations. In the spring Murphy had actually tried to impede the Giraud-de Gaulle union. According to Macmillan:

The situation vis-a-vis the Giraud de Gaulle 
negotiations is becoming very difficult. My colleague Murphy is back at his old tricks and trying to impede the union, without quite consciously admitting (even to himself) that he is doing so. He has an incurable habit of seeing every kind of person and agreeing with them all in turn. (64)

Instead of recognizing that Giraud represented a political viewpoint that was too far to the right to be acceptable to the majority of the French and which was not in keeping with American ideals, Murphy was trying to maintain exclusive control for Giraud. At the same time the Giraud-de Gaulle conflict was working itself out, another one was taking place in North Africa involving Murphy and Doolittle. 
NOTES

CHAPTER VI

1. Robert Dallek, Franklin D. Roosevelt and American Foreign Policy 1932-1945 (New York: Oxford University Press, 1979), 367 .

2. Hull, Memoirs, II, 570.

3. Dallek, Franklin D. Roosevelt and American Foreign Policy 1932-1945, 377 .

4. FRUS 1942 II, 495.

5. Ibid, 416 .

6. Crusoé [Jacques Lemaigre-Dubreuil], Vicissitudes d'une Victoire (Paris: Les Editions de l'Ame Française, 1946), 82 .

514 .

7. FRUS, Conferences of Washington and Casablanca,

8. Ibid.

9. Dallek, Franklin D. Roosevelt and American Foreign Policy 1932-1945, 377 .

10. Mast, Histore d'une Rébellion, 430.

11. FRUS, Conferences of Washington and Casablanca, 705.

12. Mast, Histoire d'une Rébellion, 430 .

13. Dallek, Franklin D. Roosevelt and American Foreign Policy 1932-1945, 378 .

14. Elliot Roosevelt, As He Saw It (New York: Duell, Sloan and Pearce, 1946), 76.

15. Ibid.

16. Eleanor Roosevelt, This I Remember, (New York: 
Harper, 1949), 281.

17. Crusoé, Vicissitudes d'une Victoire, 60.

18. Mast, Histoire d'une Rébellion, 379.

19. Ibid, 410 .

20. Ibid, 379 .

21. Doolittle to Hull, April 5, 1943, 851R.00/2518.

22. Mast, Histoire d'une Rébellion, 386 .

23. Ibid.

24. Ibid, 390 .

25. Doolittle to Hull, January 8, 1943, 8515.00/238.

26. Ibid.

27. Mast, Histoire a'une Rébellion, 432 .

28. Ibid, 433 .

29. Ibid, 434 .

30. Ibid, 453 .

31. Stimson Diary, No. 8, May 12, 1943.

32. Ibid.

33. Ibid.

34. Hull, Memoirs, II, 1218.

35. Sherwood, Roosevelt and Hopkins, An Intimate History, 679 .

36. Ibid.

37. De Gaulle, Mémoires de Guerre: L'Unité, 93.

38. Ibia.

39. Doolittle to Hull, April 5, 1943, 881.00/2518.

40. Ibid.

41. Doolittle to Hull, April 27, 1943, unnumbered.

42. Ibid, April 5, 1943, 851R.00/2518. 
43. De Gaulle, Mémoires de Guerre: L'unité, 101.

44. Hul1, Memoirs, II, 1220.

45. Ibid, 1217.

46. Despatches on Doolittle's impression of de Gaulle, which were in the possession of his daughter, are not in the Archives. One wonders if material that was favorable to de Gaulle was removed from the State Department

files as those justifying Vichy such as Hull, Murphy and Langer and others had access to these files to write their accounts.

47. De Gaulle, Mémoires de Guerre: L'Unité, 100.

48. Doolittle to Hull, June 22, 1943, 851.01/2462.

49. Ibid.

50. Ibid.

51. Doolittle to Hull, July 1, 1943, Katya Coon.

52. Ibid.

53. Ibid.

54. Ibid.

55. Ibid.

56. Ibid.

57. Ibid.

58. Ibid.

59. Ibid.

60. Ibid.

61. Harold Macmillan, War Diaries: Politics and War in the Mediterranean: January 1943 - May 1945 (New York: St. Martin's Press, 1984), 136 .

62. Ibid, 289-290.

63. Ibid, 160 .

64. Ibid, 68 . 
CHAPTER VII

RECALL OF DOOLITTLE

Unlike the Giraud-de Gaulle conflict, that between Murphy and Doolittle was not a power struggle. Instead it was a clash over whether the United States should stand by its principles, enunciated in the Atlantic Charter, and acknowledge Tunisian aspirations for self-determination or whether it should ignore these in order to keep peace with the French. The latter course was expedient militarily, and Murphy stood by it steadfastly. Doolittle, on the other hand, did his best to open Murphy's eyes to the plight of the Tunisians under the repressive policy of the French after the Germans were expelled.

When Esteva permitted the Germans to occupy Tunisia, he not only made it necessary for the United Nations to fight an extended campaign to liberate that country, but he also brought about serious economic and political disruptions. One was the severe inflation caused when the Germans imported French bank notes and threw upon the market, at their arrival, the reserve stocks of wheat and foodstuffs built up by Admiral Esteva. Although ample supplies were available at first, shortages soon followed, and the black market became the only source of food. While 
the rich could survive, the poor nearly starved. With Italian guidance the Germans also looted the textile and clothing stores and distributed their goods to the Tunisians thus to show their friendiness.

Politically French authority had been severely shaken by the occupation. The administration had almost collapsed. The French civil control officers who had resisted the Axis had been arrested by the Gestapo, usually after being denounced by the Tunisians, local Italians or Frenchmen belonging to the Service d'ordre de la Légion (S.O.L.). Those who collaborated had come under the control of the local caids, the chiefs of the S.O.L or the occupation authorities. When the Germans left many of the French collaborators left with them.

In general, the Germans were hard on the French population. They requisitioned and occupied French homes while the terrified owners remained cowering in the basement. While some of the Germans, usually the higher ranking ones, were correct in relation with the French, others carried away household property when they left before the United Nations advance. The Italians, dominant after the Axis occupation had taken place, also treated the French and Tunisians badly. Encouraged by the Fascists, who distributed black shirts, they looted and humiliated the French. The Germans and Tunisians also engaged in looting. For the most part, any farm whether Tunisian or French was pillaged if it were abandoned. 
While the French suffered under the Germans, it was nothing compared to the Jews. Albert Memmi, a Tunisian Jewish author, described vividly in La Statue de Sel what it was like to be Jewish during the German occupation. Measures against the Jews started the day after the Germans landed at the airport. During the night the Germans had installed their command posts. The following morning the German commander took the first anti-Jewish measure.

Armed with well made lists, the German police, accompanied by French colleagues went to collect several hundred hostages. It was announced that at the first refusal they would be shot. Then the requisitions, the exactions and the assassinations began. (3)

On the eighth day the Germans required all Jewish men eighteen to forty to assemble so they might be sent to concentration camps. The first response of the Jewish community was to send a delegation to Admiral Esteva to ask for advice and protection. He simply sent it away declaring he was under the orders of the Germans. Memmi himself was in one of the camps. (4)

In Tunisia Jewish property was requisitioned while in rural areas Jews were forced to sell their holdings of olive oil and turn the proceeds over to the Germans. There were compulsory Jewish labor gangs, the expenses for which were borne by the Jewish community. There was a levy to defray Anglo-American aerial bomb damage. In a report prepared by the United States Treasury, it was estimated that the monetary cost to the Jews was $100,000,000$ francs 
$(\$ 2,000,000)$.

military requisition of property $30,000,000$ maintenance of compulsory Jewish labor gangs $60,000,000$

levy to defray Anglo-American aerial bomb damage $20,000,000$

fine for Jewish labor desertions $3,000,000$ To underwrite the expenses imposed upon them, the Jewish community in Tunis made a capital levy of ten to fifteen percent upon the property of its members and borrowed funds from French banks at high rates. Individuals were forced to sell property and personal effects to meet their levies. Much of their property was mortgaged to French banks. After the liberation, the banks threatened mortgage foreclosures on those who had not met their payments because of lack of funds. (5)

After the United Nations retook Tunisia, Henry Morgenthau took a personal interest in this matter. He asked the American Consul General in Algiers to urge the French to adopt a program to undo the economic hurt inflicted upon the Jews in Tunisia. The matter dragged on for several months during which time the President was kept informed. In November 1943 Consul General Wiley advised Morgenthau that "in view of local political considerations" presentation of the program seemed inadvisable. Not meddling in French politics was consistent with American policy in North Africa. Apparently there was a "bitter dispute" (6) in the State Department over the program. The Political Division of 
the State Department clained that the problem was an internal one for the French and that it should make no recommendation even though Dean Acheson supported Morgenthau's position. Finally the American position was presented in late November and December to the French who said they would give it further study. (7) This same problem of whether or not to interfere in French affairs was involved in the Doolittle-Murphy conflict which came to the attention of the President in November 1943.

While the middle class Tunisians stayed neutral, many of the poorer Tunisians collaborated at the beginning of the German occupation. The fact that the Germans were the conquerors gave them prestige. The Tunisians may have been even more impressed by the way the German soldiers treated them as equals and made no distinction between them and the Europeans. The Tunisians preferred the German soldiers, who ate in their houses and played with their babies, to the French who treated them poorly. According to Memmi, it was a miracle that the Tunisians were not completely won over by the Nazis, for nothing was overlooked - promises of independence, Arab radio broadcasts by Radio Berlin, and reminders of the Islamic friendship of William II.

The Bey, of course, was the object of special attention by the Axis. During the occupation both the German and Italian consuls tried to establish direct relations with him only to be referred back to Admiral Esteva. The Bey told them that all transactions should be carried on through 
normal channels. (10) Attempts were made to get the Bey to declare war against the United Nations and, after an especially bad bombing of Tunis, to have him condemn publicly the barbaric methods of the Anglo-Saxons. He refused both of these. He also refused the Italian consul's suggestion that he denounce the French treaty of the Protectorate and replace it with one with Italy. Instead, the Bey told the Italian consul that he would be grateful if the Italian government, which was holding members of the Destour in Rome, including Bourguiba, would hasten their return to Tunisia. The consul left the palace "white with rage." (11)

From the beginning of the occupation the Italian and German consuls pressured the Bey to bestow decorations on a list of twenty-six of their countrymen. The Bey interposed objections and inquired of Admiral Esteva if it would be in keeping with his November 8,1942 position of neutrality. Esteva replied that conferring the decoration was not incompatible with his position. Finally on April 30 the Bey presented the decorations in the presence of Esteva. These actions of the Bey were of importance later when Hooker Doolittle would urge his superiors to resist the French desire to depose the Bey because of his alleged collaboration. (12)

The Bey, who had begun to regain some of his powers from the French before the invasion, became increasingly independent during the occupation. The Germans treated him 
as an autonomous sovereign. One example of his independence was seen in an interview the Bey had with a representative of Pétain from Vichy as reported in a Tunisian newspaper. According to Doolittle, it was noteworthy that the interview had been published at all as it never would have been under the French. In the beginning of the interview, the Bey asked about the "health of the Marshal for whom he held a particular affection." (13) He said also that he hoped that in the future Tunisia and France would have a common destiny. In spite of the many errors committed by the French, the Bey declared "we desire to pass the sponge over the past." (14) The Bey continued by stating that he had named new ministers and that he was certain France would "demonstrate her comprehension and justice." (15) The Bey brought up the list of Tunisian claims that had been presented to Esteva the previous year. The representative requested a copy and said he was sure the Marshal would support a new policy in Tunisia. Doolittle remarked that the outspokenness of the Bey demonstrated that French control was "illusory if not actually non-existent." (16)

One of the ministers the Bey appointed was Habib Bourguiba who had been imprisoned in Marseille without trial since 1938. When the Germans occupied all of France in November 1942, they sent him to Rome, where they hoped he could be used for propaganda purposes. Apparently they were unaware that in October 1942 Bourguiba had sent his wife and son back to Tunis with a personal message to the 
American consulate that ample time for reflection had made him realize that the Tunisians could expect nothing from the Germans and that he was telling his followers to support the United Nations. (17)

As an example of this support by the Destourians, Doolittle in a letter to Murphy, pointed out that in February 1943, when Rommel made his push against Kasserine and drove the Americans and French out of Tozeur and Nafta, areas where the Tunisians had always been considered very anti-European, the retreating French asked the Destourians of Tozeur to handle the policing of Tozeur. They did such a good job that no looting took place there "and not even the Jews were molested." (18)

Even though Bourguiba was treated handsomely by the Italians in Rome, he resisted their attempts to have him ally himself with the Axis. While he made a speech from Rome to the Tunisians, he made it sufficiently ambiguous to give no aid to the Italians. In fact, he was probably referring to Italian designs on Tunisia when he said "while our country is the theater of operations it is at the same time a booty of colonization." He ended by saying that "he hoped to join them as soon as circumstances permit," (19) and by asking the Tunisians to obey Moncef Bey.

The Axis sent Bourguiba back to Tunisia in March of 1943. While he found that some of the Destourian cells had cooperated with the Germans, won over by the promise of 
freedom and independence, he quickly took the matter in hand and turned the Neo-Destour back in favor of the united Nations. Bourguiba wrote,

My first care was to put the brakes on the purely sentimental movement which carried certain militants toward the Axis powers because they had liberated all the imprisoned Destourians. (20)

While it would still be several months before Doolittle would be involved directly with the economic and political problems caused by the German occupation, he was already anticipating them in constantine. The economic situation, he said, would be catastrophic with "ruined ports, railroads, electric plants, water supplies," (21) all of which would have to be reestablished immediately. Politically the situation would be more complicated. The French would undoubtedly throw out the Vichy partisans in the administration but the status of the Tunisians, who constituted five-sixths of the population, would still present a "very delicate" problem. (22)

Before the United Nations invasion of November 8 the Bey of Tunis had begun to regain from the French Resident General some of his powers. Doolittle said the latest information from Tunisia indicated the Germans were treating him as an independent sovereign. Because of the political sophistication of the urban Tunisians and because the Germans were playing up to him, Doolittle believed the French could no longer treat the Bey solely as a puppet. Since the Americans would have the primary responsibility of 
feeding, clothing, and reequipping Tunisia, he thought they should serve as a buffer between the French and the Tunisians. Because of its role in supplying the "stricken Tunisian population," (23) the United States should be in a position to impose its decision on these opposing groups. To do this, there should be an American representative with definite instructions as to policy and with authority to carry it out. Although in this despatch to his superiors in the State Department Doolittle was arguing for an American policy to be established which would allow the American consul in Tunisia to serve as an intermediary between the French and the Tunisians, this was later to be denied him, and he was not to be consulted on Tunisian policy.

For their part the French, well aware of the prestige they had lost during the German occupation, were making their own plans to reestablish their authority as soon as Tunisia would be recaptured. One obvious step needed was to unify the two factions so there would be one definite authority. In a report to the Free French in London in April 1943, the Secretary General of their Algerian mission reported that Tunisia was in a chaotic state with two enemy armies and five United Nations armies operating there. Each army was recruiting their political agents among the French or the Tunisians. According to the Secretary General, the French administration had disappeared or had no more prestige. The leading Tunisians were absent while those who had collaborated had fled with the Germans. The faithful had 
been taken to the rear. Every troop was acting as its own police, administering on the spot, and pillaging at random. To reestablish order the secretary General thought it crucial that the political and military unity of the Empire be achieved. He meant, of course, a solution to the Giraud-de Gaulle problem.

To delay this risked compromising French authority in the region which had always been the most difficult to govern in North

Africa and the most receptive to anti-French forces. (24)

Other measures were also being considered, the most important of which was the deposition of the Bey. In a report from one of the French civil controllers in Tunisia during the occupation on what steps would be necessary after the war, he thought it was "important to exploit the occasion to diminish the importance taken by the Beylical family." (25) This controller in his report pointed out the "need to be tolerant with the Destourians whose only error was to nourish premature ideas of national liberation." Perhaps because he saw the Destourians as weak, this Frenchman did not see them as the threat other Frenchman would. He also thought it would be important to ameliorate the conditions of life for the Tunisians.

In February 1943 Doolittle was assigned to Rabat, Morocco. While there he learned that the French were considering deposing the Bey. Pointing out the Bey's pro-United Nations sympathies, he wrote Murphy that he thought this was a serious mistake and that the Americans 
should intercede to prevent the French from doing it. In bringing up the question of the deposition of the Bey, Doolittle was broaching a subject on which he and Murphy were to differ profoundly.

Doolittle askea to be excused for putting in his "six cents", but said that if he was to go back to Tunisia, he felt strongly that the Bey should not be deposed. It would be an opportunity for the French to rid themselves of a Bey "with a mind of his own" (27) and to wipe out the vestiges of Tunisian nationalism, but he did not see any reason for the United States to be a party to such action.

Doolittle asked what acts of the Bey were reproached. The only ones he could think of were that the Bey had received the Germans and had decorated a German general or two. He asked though "what would any of us have done in the position of the Bey?" (28) He then asked about the pressure brought by the American Army on the sultan of Morocco for private audiences and decorations. He concluded by saying it was his opinion that "we have everything to lose and nothing to gain by deposing the most popular sovereign of Tunisia since Naceur Bey," (29) the present Bey's father. Murphy, however, took the position that it was a strictly French problem. In replying to Doolittle, Murphy told him that his letter carried the thought that the United States was going to deal directly with the Tunisian question; "I have the feeling that that is a contract which we do not want to assume." (30) Murphy believed that the 
United states probably did not want to deal directly with the Tunisians. He didn't think that the United States or the British wanted to take over the responsibility of administering Tunisia from the Erench nor did the United States want to interfere in French internal policy as long as that policy did not interfere in the war effort. Cooperation of the French was more important than the position of the Bey, as long as the protectorate was maintained. (31)

Doolittle responded by saying that he feared Murphy had missed the point. Doolittle had never meant for the United states to deal directly with the Tunisians, but, since the French and the Americans were fighting together against the Axis, whatever policy the French adopted would surely be attributed to the Americans as well. Whether the Americans wished to assume "the contract" or not, Doolittle thought the United states would be held responsible. Everyone would believe the Americans had been consulted in the matter and told the French to go ahead. Because of this, Doolittle believed that the United States should "restrain the action apparently envisaged." (32) Should it turn out badly, the French would be the first to say that the Americans approved or even ordered the action to be taken. Later events proved that Doolittle was essentially right because the French would ask if the Americans approved of deposing the Bey before they did it. Doolittle referrea to a memo prepared by Lieutenant 
Archie Roosevelt, a cousin of the President and an oss agent in Morocco. In this memo Roosevelt had come independently to the conclusion that it would be a bad policy to allow a spirit of revenge to prevail in handling the Tunisian question after the arrival of the United Nations forces in Tunisia.

Doolittle told Murphy that if he, Doolittle, were going to go back to Tunisia, he would be the person responsible for carrying out any policy or lack of policy. Even though Doolittle had not been consulted on Tunisian affairs since leaving Constantine, he thought he should have had a chance "to put a word in here and there." (33) Though Murphy did not want to upset the status quo, Doolittle asked if deposing the Bey was not in fact upsetting it. Doolittle did not think all French proposals should be swallowed without examination. Shoula the Americans follow the one about deposing the Bey, they would be turning their backs on their own public declarations such as the Atlantic Charter, and would "lay ourselves open to the accusation of talking through our honorable hats, brass-bound or silk." (34) The return of the United Nations to Tunis on May 7 began inauspiciously for the Bey. No sooner had British soldiers moved into Tunis then they attacked the summer palace of the Bey at Hammamlif and forcibly took him at bayonet point to Tunis to the office of the British Consul General. The recently arrived acting Resident General Juin had him returned to Hammamlif. The British excused 
themselves for this unfortunate incident by saying their soldiers were carried away by the heat of the moment and were badly informed. (35)

Juin, who was to serve until Mast was well enough to assume his post, had arrived in Tunis right after the British. Describing his entry, he said that he was greeted with a "a delirious enthusiasm" (36) as he passed through the Jewish quarter. He mentioned how these poor people had suffered terribly during the German occupation. As for the Tunisians he saw few of them while "the Italian colony naturally didn't put its nose outside." (37) When he reached the Residence, he found a few French and Tunisian officials and some prominent persons who had escaped being forcibly removed by the Germans, as well as some French resisters who had come out of hiding. At the Residence Juin proceeded to give his first commands restoring order. (38)

Doolittle, Murphy, and Colonel Julius Holmes, Allied Force Headquarters, visited Tunis on May 11 for three days. Doolittle found that his home, which had been used by the German military commander, had been "thoroughly and completely sacked." (39) Doolittle reported: "MY wife and I now have not even a single napkin to our names." (40) Clothing, silver, china, kitchen utensils, furniture, rugs, everything were lost. According to his daughter, Katya, it was the rugs collected in Persia and the Caucausus that he most minded losing. (41) The consulate, which had been used as offices by the Germans, had also been ransacked and the 
safes blown.

Murphy wired the President and secretary of state that the Tunisian population was enthusiastic, but affected by the destruction which had occurred. In many towns it had been quite severe while Tunis on the other hand had suffered little except for the dock area. Eight hundred civilians had been killed, but, had the bombing not been confined to the dock area, the toll might have been much greater. Other than a shortage of food and the lack of electric lighting caused by the destruction of the power plant by the Germans as they left, the situation in Tunis was almost normal. As soon as transportation was reorganized, Murphy thought there would be no serious food problems. The enemy trucks that had been seized would help solve distribution needs. While the Germans had either consumed or taken two-thirds of the livestock in northern Tunisia and one-third in the southern part, Murphy thought enough remained, along with a good cereal crop about to be harvested, to alleviate the food situation. (42)

On this trip Murphy had also visited Bizerte which was "a complete shambles, not a building in the town remained undamaged." (43) He saw many thousands of enemy prisoners on the roads and in the prison camps. In one camp there were a group of 36,000 German prisoners, principally young shock troops; in another, there were 20,000 Germans and Italians.

Included in Murphy's telegram was a report on the 
political situation. Giraud had arrived in Tunis on the twelfth and discussed with Murphy and Juin the question of the Bey. Giraud believed the Bey should not be allowed to remain in office on the grounds that he had collaborated with the Axis and permitted acts of disloyalty on the part of his subjects which militated against the United Nations effort. Giraud told Murphy that he proposed to detail Juin to suggest to the Bey "that the happiest solution would be for the Bey to abdicate." (44) When asked by Giraud whether the United States government would approve the French action in deposing the Bey, Murphy said:

There apparently is no law under which the action could be taken without invoking necessity arising out of the military situation. (45)

Murphy informed Giraud that he had no instructions from his government, but he was sure that American opinion would favor any French action that proposed to punish those who had actively aided the Axis during the course of the Tunisian campaign. He said the internal affairs of the Protectorate lay between the competent French and Tunisian authorities. (46)

While it fell upon Juin to execute the decision to depose the Bey, he claimed in his Mémoires that the order bothered him since he did not wish to commit an injustice. After making an inquiry, Juin could discover nothing serious against the Bey. All one could reproach him for was having conferred some decorations on some enemy personalities at the insistence of the Resident General. He had formally 
refused to recognize them himself. The only other complaint invoked against him was his pro-Neo-Destourian sympathies. Nevertheless, the Committee at Algiers was insistent on profiting by the disarray and shock produced by the defeat of the Axis. According to Juin, since "the instructions had once again an imperative command, he had no choice but to obey." (47)

Juin called on the Bey on May 13 and asked for his abdication explaining that the decision had been made in Algeria. The Bey insisted that he would not abdicate. After three hours, Juin left saying he would wait until four p.m. for his decision. At four with the Bey's decision unchanged, Juin had him flown with a reduced entourage to Laghouat, Algeria near the Sahara. Juin had hoped that, since he had never flown, he would change his mind and abdicate. Instead he showed a joy, which Juin patronizingly called childish, in mounting the plane. With the approach of summer being at Laghout, according to Juin, was not "a beautiful gift." (48) In his Mémoires Juin said, in recalling these events, that he regretted that the "pseudo-government of Algeria", in haste and in ignorance of the exact facts of the political situation, had required of him "an unwise act to the detriment of a sovereign to whom there was nothing grave to reproach and who had always been loyal." (49)

The Tunisians were devastated by the deposition of the Bey. They went into mourning for three days, shutting their shops and praying in their homes. (50) Whereas there 
had been some Tunisians favorably disposed toward the French, the deposition had the effect of turning them unanimously against them. As French historian Charles-André Julien wrote, "in eliminating Moncef one had created Moncefism which was to give to nationalism a virulence without precedent." (51) He continued,

Moncefism took on a passionate character that did not let up until the death of the Bey. It was around him that nationalism crystalized. . . The inconsiderate decision of General Giraud executed hastily but without conviction by Juin rendered all French Tunisian rapprochement impossible and furnished a solid basis for Destourian opposition. . . (52) The French Committee should have shown itself more prudent. With the exception of General Catroux who said the era of colonial domination had ended, the technicians surrounding de Gaulle and Giraud had forgotten nothing and learned nothing. (53)

Juin had one last "thorny case", âs he called it, to handle before leaving Tunisia and that was the presence in Tunisia of Habib Bourguiba. The latter had gone into hiding when the United Nations entered Tunis since he was not sure what his legal status would be with the return of the French. Bourguiba, according to his own account, had refused to follow the Germans, who had proposed to take him to save the head of the nationalist movement. "I refused in order not to compromise the party and the unity of the Tunisian movement." (54) Persuaded that the Axis forces were going to an inevitable defeat, he thought the Neo-Destourians had no interest in finding themselves at the end of hostilities on the side of the defeated. 
He knew, however, that the Allies at Tunis would mean the presence of the French partisans of de Gaulle or of Giraud and in short the French whatever their tendency would be in agreement that Bourguiba and the Destour constituted the enemy. (55)

Bourguiba was quite right that the French looked upon him as the enemy. Juin referred to him as "the Destourian agitator." (56) Juin, however, did say that, in truth, Bourguiba had not compromised himself and since his arrival in Tunis Juin had verified this.

Bourguiba sent an emissary to seek an interview with Doolittle. He wanted him to intervene with the French to have them lift the order for his arrest. While Doolittle rejected this demand, since it was not part of his job, he did take the opportunity to tell Juin that Bourguiba had been detained illegally during five years and that appeared to him unjustifiable. He suggested that the order of arrest be rescinded, that he talk to the Destour leaders and use them as instruments of French policy rather than "make of them outcasts and martyrs and thereby lose all touch with the very considerable body of Arab opinion which they represent." (57) Juin told Doolittle that his orders were to arrest Bourguiba, that he could not disobey, and "that to assuage British and American opinion these present measures against the Arabs were necessary." (58) Juin, at that point, seemed to be blaming the Americans for the hard line he was taking against the Tunisians. This was precisely what Doolittle had told Murphy the French would do. Doolittle replied that he was unaware of any great British or American 
opinion which demanded such repression and that if it did, it was obviously misinformed. "Now that France was again becoming strong, she could afford to be generous." (59)

Bourguiba, as he would recount later, recognized that while the war lasted against the Axis powers, the United States did not want to displease the French or hurt their feelings. Bourguiba believed that such a policy was justified at a time when Vichy propaganda was attempting to raise up the French against the United Nations by accusing the English and Americans of having designs on North Africa and wishing to defraud the French of their colonial possessions. (60)

In fact, Bourguiba wrote a manifesto when the French returned to Tunisia asking his followers to put aside until after the war their nationalistic ambitions and join the Fighting French in the war against the Axis. The French authorities, however, refused to allow the diffusion of this appeal. According to Bourguiba,

They were aware of the fact that from the moment it would be published it would be difficult to justify the repression of a movement which declared itself ready to cooperate with them. (61)

Doolittle thought the manifesto had irritated the French because it implied that they would also make a gesture of reconciliation. Doolittle found it ironical that Bourguiba had said that he could speak freely now because he was confident that the United Nations would not let the French proceed in a spirit of revenge and that "the way is 
open for a fruitful collaboration." (62) Doolittle commented "nothing of the sort. No Tunisian can speak freely. An answer of any kind to the most unjust accusation is taken as insolence." (63) The French had shut the door unfortunately to any collaboration and had alienated the Tunisian bourgeoisie "who had always been sincerely Francophile and remained so during the occupation." (64)

The United States was pretending, according to Doolittle in a despatch to the state Department, that this was a matter for the French alone and would not see that the French were not able to overlook their own pettiness.

Led by a stiff-necked and stupid military clan, overloaded with generals of 1906 vintage and admirals without ships, they suddenly find, at the behest of selfish colonists and inefficient administrators, that now that France as embodied by the handful of colonial rejects and selfpromoting armchair warriors in North Africa, is great and powerful and therefore must take the strong hand with a helpless native population. They forget that sixty years of the strong hand had done nothing to endear them nor to create a group of native collaborators animated by no other motives than that of splitting the proceeds of exploitation of the fellah with the French officials set over them ostensibly to guide and control. (65)

Doolittle had heard that Allied Force Headquarters had issued orders saying no members of the Destour should be arrested simply because they were Destourians, but by a peculiar coincidence most of those arrested were known as Destourians.

Besides leaving the order of arrest for Bourguiba in place the French had instituted harsh and repressive 
measures against the Tunisians. Doolittle wrote:

As I had foreseen, the French, not the Tunisian French but the French military administration in which few changes in mentality or efficiency are to be observed came into Tunisia in a spirit of revenge for their three years of humiliation. It was obviously necessary to find a scapegoat for the acts of the French administration and what more natural and easy than to choose as the scapegoat the Arabs of Tunisia with their Bey and childish attempts at nationalism. (66)

It should be realized, Doolittle continued, that it was not the Tunisians who allowed the Germans to enter, but Admiral Esteva and General Barré, the two responsible heads. Nor was it the Bey and his court who had requisitioned animals and provided foodstuffs for the Germans during the occupation, but again it was the French administration. The Bey had refused to sign decrees given to him on this score. Admiral Esteva himself had done this by Residential orders. Nor was it Moncef Bey who had organized the North African Phalange which sent young Frenchmen to fight against their brothers under General Giraud. Inspite of all this, when the Army of Liberation entered Tunis, they immediately deposed Moncef Bey and began a series of arrests, the number of which was reported at about five thousand. While Doolittle agreed that "pillagers, spies, and denouncers should be apprehended and punished," (67) very few Tunisian notables were known to have collaborated with the Germans. None of the French officials who underwent the occupation were consulted as the steps to be taken and several protested vehemently against the actions and considered resigning in 
protest. Doolittle pointed out that neither he nor Vice-Consul John Utter had been consulted in Tunisian matters since leaving Constantine. (68)

The new Bey, Sidi Lamine, accepted the post only to preserve the Hussenite Dynasty. New ministers were chosen by the French to replace the ones that Moncef Bey "had had the effrontery to choose for himself." (69) Two of these new ministers had talked to Doolittle about the unfairness of deposing Moncef Bey. The Tunisian bourgeoisie, whose conduct during the German occupation was dignified according to Frenchmen who stayed there, "was disgusted and worried." (70) Numbers of Tunisian merchants had not reopened their shops in the souks, and the peasants in the outlying districts were afraid to bring in their products. There was an atmosphere of repression and terror. (71) American prestige was high in North Africa at that time. Doolittle asked if the United States was to let it be dimmed because it turned its back on the series of injustices of the French. "By their acts since 'liberating Tunis' the French have made the Tunisians more unanimous than formerly in detesting them." (72)

It was also true that the Tunisians had a first hand knowledge of what German occupation meant. With the exception of a few who profited, most of the Tunisians found it worse than expected. "Here then was a malleable material ready for use through a policy of generosity and understanding." (73) The Erench told the Americans to tell 
the Tunisians to settle their differences with the French. Yet this implied two sides to the bargain. Doolittle asked, if the French themselves refused to settle, how could the Tunisians arrive at a settlement? (74)

Doolittle thought the Americans, "the torchbearers of freedom", should accept the responsibility they had assumed by landing in North Africa by making their voice heard in the policies that affected not only North Africa, but the whole Islamic world. He wrote:

Any observer here in North Africa is soon forced to the conclusion that the French are psychologically sick. Their division, their petty quarrels, their lack, with a few notable exceptions, of any will to help themselves out of the muddle, their tendency to call upon the British and Americans to help them, and not only to help them but to do everything for them, and then object to measures taken indicates that they need a rejuvenation of spirit and a direction which they themselves are incapable of furnishing. (75)

Doolittle thought that the Americans had the men and material to give the French a new direction. If so, the men must be given the authority and those with specialized knowledge should be consulted. (76)

Doolittle supplemented his despatches of this time with a telegram.

Present policy toward Tunisian Arabs is disastrous. The army of liberation in three weeks has succeeded in what 60 years of occupation has failed to do, unite the Tunisians solidly against the French. (77)

He continued that the United Nations were blamed for the deposition of the Bey. The situation had degenerated into "a reign of terror, arbitrary arrests, beatings, and 
torture." (78) Forced labor was being obtained by police roundups. Instead of returning to Tunisia "to heal the wounds of German occupation," the French had returned "as to a conquered country." He reminded the state Department that the army that was to be raised in Tunisia would be largely composed of Tunisians. A copy of this as well as all of his despatches went to Murphy who apparently ignored them. For his part, Bourguiba wrote a long letter to President Roosevelt asking him to help the Tunisian people, who were being treated poorly by the returning French. Bourguiba described how repression of Tunisian patriots had started with the events of April 9, 1938 when the militants and the party chiefs had been put in prisons and concentration camps in France and Tunisia.

This repression, which ironically had only known a moment of respite during the German-Italian occupation, has started again with an accelerated rhythm. Inspired by a desire to humiliate and terrorize the people and taking advantage of the terror weighing on the country, the heads of Free France have by an unparalleled blow deposed the legitimate sovereign of the country, Sidi Moncef Pacha Bey, who in spite of advances and pressures of the Germans and Italians had obstinately remained neutral and faithful to the French Protectorate. Thus by an irony of a sort which is particularly cruel to Tunisian democratic hearts the victory of the Democracies in Tunisia had established methods which were most authentically fascist. (80)

Bourguiba said the Tunisians were putting all their hopes in the President to intervene with the Free French "who were fighting against Nazi enslavement to see that they did not treat the Tunisians as an enslaved people." (81) Bourguiba 
believed that the United Nations could not be indifferent to the crisis in Tunisia for the errors being committed by the French "out of a spirit of revenge could not but nullify the Allied war effort by alienating precious sympathies." (82)

Suddenly on June 6 a member of Juin's staff informed Doolittle that, if Bourguiba presented himself to the Director of Security, Juin would give him and his immediate colleagues, their provisional liberty whereas, if he did not, he would be shown no mercy. Doolittle relayed this proposition to Bourguiba's Destourian friends. They replied that Bourguiba wished to meet Doolittle. Doolittle accepted, and the two met clandestinely at night. Bourguiba wanted to inform Doolittle of Tunisian nationalist goals, while Doolittle wished to know the truth about the accusations that Bourguiba had collaborated with the Axis. Doolittle was quoted on the occasion of a celebration of this meeting:

I did not know him before. From the first contact, he enchanted me. He was really bubbling, a real force in action like an overcharged battery. He pleaded the Tunisian cause, naturally. I was already won over to the cause he was defending. By the time we separated, we had become two good friends. (83)

Bourguiba presented himself to the Director of Security and at first was met coldly by the Director who asked what his demands were. When Bourguiba replied that he had come, as requested, to regularize his juridical situation which was not clear, since he had been imprisoned by the French and Iiberated by the Germans, the Director 
became more cordial. Bourguiba told him that he had no plan of creating public demonstrations, but, if treated with understanding, would be happy to try to "disintoxicate the Tunisian people from the poison left by the German occupation." (84)

In reporting this to the state Department, Doolittle remarked that "in spite of injunctions not to meddle in Arab affairs as being exclusively a function of the French administration" he thought

a constructive act has been taken. The fact that the French themselves came to the Consulate for a matter of this kind indicates that they recognize that we have a certain right to be consulted on their policy inasmuch as we are all engaged in the same struggle. (85)

Doolittle was far too optimistic about the French. Juin's version of this, as given in his Mémoires, was quite different. He said there was "not a day that passed that I was not pestered" (86) on the subject of Bourguiba's freedom by his American friends. Juin thought it "of public notoriety that the Americn diplomatic agents in North Africa always made themselves the advocates of the most active nationalists." (87) According to Juin's account, Doolittle insisted that Bourguiba be authorised to come see him, but since Juin did not wish it at any price he replied that he could see his Director of Security who would give him his instructions. (88)

Having given Bourguiba his freedom, Juin left Tunisia in June 1943 and was replaced by Mast. Little or no change 
in French policy toward the Tunisians was apparent. Bourguiba found Mast's policy as repressive as Juin's had been. Mast no sooner arrived in Tunis than he sent a despatch back to Algiers saying that it was desirable to obtain the abdication of Moncef Bey. Mast reported that the Destourians were telling the Tunisian population that the new Bey was not legitimate. The new Beylical court was upset by rumours that the return of Moncef Bey was imminent and that his return would be because of American pressure. Mast wanted to suppress this agitation by obtaining the Bey's abdication in exchange for his being moved to a more tolerable climate on the seashore. (89)

Nor was the arrival of de Gaulle in North Africa to cause any noticeable difference as far as French policy toward the Tunisians went. Though he had not arrived in North Africa at the time the Bey was deposed, he expressed his approval of the measure in his Mémoires, saying that it was necessary because the Bey's "attitude had been troublesome with regard to the obligations that had linked him to France." (90) He went on to say that the committee had no more serious problems in Tunisia after that and that he supported Mast who, he said, was doing his job with intelligence. Furthermore, he blamed Esteva, whom he referred to as "that unfortunate man", for causing serious political consequences when he allowed the Germans to occupy the country. (91) The presence of the Germans and Italians in Tunisia had given "agitators many occasions to turn the 
citizens against France." (92) For imperially minded Frenchmen any nationalist could by labelled "agitator". By his actions in Lebanon in November 1943 de Gaulle demonstrated his general attitude toward nationalists; he dissolved the newly elected parliament, suspended the constitution, and arrested the ministers. (93)

Doolittle's concern for the Tunisians bothered the French. Before Juin left Tunisia, he wrote Giraud that the Americans were critical of the deposition of the Bey and thought it harmful to the united Nations cause. Juin believed the Americans lent too attentive an ear to the complaints of the Beylical milieux, and he feared that their solicitude extended to the nationalists as well. (94) When Mast arrived, he also complained about Doolittle and actively pursued obtaining his removal.

Under pressure from the French, Murphy now began seeking Doolittle's recall. In first bringing up the matter with the state Department, Murphy said that he personally liked Doolittle and "admired his idealism" and did not like to suggest his transfer, but thought it might be necessary. (95) Murphy was disturbed about "the independent policy pursued by Doolittle in respect of the Arabs in Tunisia." (96) Since his return to Tunisia Doolittle had not disguised his disapproval of the deposition of the Bey and had encouraged the Tunisians to come to him with their grievances. Murphy admitted that "the French may have been too aggressive in punishing those who had aided the Axis," 
but Doolittle was the only person he knew who called it a "reign of terror." (97)

While despatch after despatch had flowed from Doolittle to the state Department with copies to Murphy about the Tunisian situation, now telegram after telegram, all secret, started flowing to the state Department from Murphy with no copies to Doolittle about the Doolittle situation. Although Murphy at first had only suggested that Doolittle's recall might be necessary, he soon was actively building up a case against Doolittle in order to obtain his recall.

He reported that an observer who had just come back from Tunis was worried "that Doolittle had gone so far out for the Arabs that a serious French reaction had set in against him." (98) The same observer said the French resented Doolittle's intervention on behalf of Bourguiba. This was in accord with Juin's opinion as quoted above. After Doolittle had intervened for different Tunisians several times, the French second Bureau decided to ignore his interventions "because of his advanced partisan attitude." (99)

Murphy then sent letters from two different American Army officers, who were stationed in Tunisia, saying that Doolittle was overstating his case. However, both admitted that there had been instances of mistreatment and that French methods were "somewhat more drastic" than American. (100) 
Murphy also sent a complaint from the French Director of military security about Doolittle. On June 27 Doolittle had visited a camp of internees in sousse accompanied by Lieutenant Archie Roosevelt and by a Tunisian, Abdelaziz Hadj Hussein, also known as "Slim Driga", to inquire about the latter's brother, Abdallah. Slim Driga was the one who had climbed the garden wall with the message from the Bey after the German occupation when Doolittle was confined and just before his escape. In an interview with Abdallah, Doolittle learned that he was poorly fed and ill-treated. Doolittle told the warden that he was going to try to have Abdallah released, as he had done inteligence work for him against Italy, and he did not consider that having belonged to the Destour Party a serious offence. The French Director thought Doolittle's attention should be called "to the irregularity of any direct action on his part, which might well be interpreted as an attempted interference with the rights of sovereignty of France over its own subjects." (101)

Murphy had discussed with General Mast, just before the latter assumed his duties as Resident General, what his policy would be in dealing with the Tunisians. Mast assured Murphy that he would "avoid anything savoring of repressive brutality in dealing with the Arabs." (102) For those Tunisians responsible for treasonable conduct or criminal acts, they should be punished, but he planned to follow judicial procedures and make every effort to avoid 
injustice. (103)

Doolittle's despatches and Murphy's telegrams did not go unnoticed at the state Department. Paul Alling, Assistant Chief of the Division of Near Eastern Affairs, now wrote Murphy asking for his comments on the French policy of deposing the Bey. Murphy replied that he did not agree with the statement of Doolittle that "we had nothing to gain and everything to lose by the deposition of this Bey." (104) Murphy thought United States policy had been that the French authorities were "responsible for the native policy in North Africa" (105) and, if the Americans had reversed this attitude in the case of Moncef Bey, it would have had an adverse effect on American relations with the French. Murphy admitted that the Bey had never been proven to be actively pro-Axis, but that his feud with the French administration of the Protectorate before the Germans came played a decisive part in his removal. (106)

In late July Doolittle was recalled to the Department "in order to clarify the issues." (107) While Doolilttle was on his way, wallace Murray, Adviser on Political Relations, on July 27 sent a long memorandum to Adolf Berle, Assistant Secretary of state, summarizing the differences between Murphy and Doolittle. Murray pointed out to Berle that the two "took diametrically opposed positions." (108) Murray thought the proper policy lay somewhere in between.

The attitude of Murphy, according to Murray, was quite understandable and was based on the status quo in French 
North Africa that he found when he was sent there to work with General weygand. Obviously the objective then was "to leave no stone unturned to gain the goodwill of the French masters of that area" (109) and enlist their active collaboration in the military landing. Murphy pursued this loyally and with great success. Murphy could not be worried about whether French rule was just or unjust. His assignment was to win over the French and he could not have done this if he had tried "to carry water on both shoulders" (110) by worrying about complaints of the North Africans against the French, no matter how justified.

Murray went on to say that Doolittle, whose North African tour of duty went back to 1933 , knew more about "native problems" and was more inclined to see the point of view of the Tunisians than to adhere to "Mr Murphy's rigid objective of dealing solely with the French and steering absolutely clear of native problems." (111)

While Murray believed that Murphy's policy was sound before the landing and through the close of military operations, it should not be followed indefinitely. In view of the policy the united states had adopted for subject peoples and their aspirations as stated in the Atlantic Charter, the United States could not ignore Tunisian aspirations. Should the United states do this, it would reinforce the British belief that the Americans were peculiarly interested in maintaining the French Empire while undermining the British Empire by their sympathy for 
India. (112)

Murray pointed out that of the three French areas in North Africa, two, Morocco and Tunisia, were protectorates and not parts of the French Empire. Both had been independent countries with which the United states had diplomatic relations. Neither country had forgotten its lost independence, and there was every chance that sooner or later the United States would be reminded of the articles in the Atlantic Charter stating that peoples shall have governments they choose. While Tunisia and Morocco might not be ready to assume independence, Murray wondered whether their ability to rule themselves was any less that that of the Ethiopians or Afghans whose independence the United States didn't question. In his opinion, the problem might "come home to haunt us in due time and that the unduly prolonged policy now being pursued by Mr. Murphy will not be good enough in the long run." (113)

Berle wrote Murray that his memorandum about the deposition of the Bey was "extremely interesting." (114) He had heard the same differences of points of view that the cables from Doolittle and Murphy expressed from other people returning from North Africa. The dilemma was that, while the French colonial system was far from perfect, American soldiers were not there to revise it but to restore France and fight the Germans. Berle said it did appear that the Bey did not deserve the treatment he received. The way the Tunisians were treated appeared wrong too. Still, he 
questioned whether the United states was entitled to use the war to improve European colonialism. While the Americans would like to do much, he did not think they should be "too expansive about it." (115)

He suggested proposing a commission, made up of French, to study the administration of Tunisia. While the United states would have to be careful, he thought forces could be set in motion to improve the situation. The only right to say anything, beyond that, woula be if American forces were endangered by ill-considered measures of the French that might provoke a Tunisian uprising. Berle asked Murray to think about what the United States could do. Referring to the remark of Doolittle about the colonial policy of the "1906 vintage", he said that "besides being inherently immoral, French policy may offer very solid and political dangers." (116)

Mast made a trip on July 29 to Algiers to protest informally to Murphy about the policy of Doolittle. Unfortunately, Doolittle, who had stopped in Algiers en route to the United states, had just left that morning. otherwise, Murphy wrote, he would have insisted on a joint conversation. Mast asserted that Doolittle had associated "with Arab enemies of the French administration acting as their counselor and adviser and encouraging them to be anti-French." (117) According to Mast, Doolittle had connected Lieutenant Archie Roosevelt with these activities causing the Tunisian leaders to believe that President 
Roosevelt favored the policy of Doolittle. Mast continued that the French administration was increasingly embarrassed by the activity of Doolittle "in cultivating and supporting anti-French leaders" (118), which was being interpreted as an indication that United States' policy was unfriendly toward France. Mast was aware that the attempt of Doolittle to defend Tunisian rights was primarily a personal matter, but he thought it best if Doolittle did not return to Tunis. Murphy assured Mast the United States had no intention of supporting anti-French activity. While in Algiers, Mast took advantage of his "friendly relations with Eisenhower," (120) whom he had known from the time he had served as head of the liaison mission to the Allied Force Headquarters, to discuss the Doolittle matter with him and Bedell Smith. Requesting that Doolittle not return to Tunisia, Mast put it on a purely military plane referring to his need to maintain the order and the security of Tunisia which served as a base for United Nations operations. Eisenhower told Mast that he agreed that Doolittle had gone beyond his job as consul, and he assured him that the consul General would not regain his post. Mast also obtained the assurance from Eisenhower that Lieutenant Archie Roosevelt would be sent to another theater of operations. Mast thought Doolittle used Roosevelt because of his name. (121)

In Algiers Mast, of course, talked to the French administration about 
relations he maintained with influential

members of the Destour, the violent criticisms

he directed against the Protecting Nation and

how the Doolittle administration had unsettled

circles favorable to France. (122)

On his return he wrote that he believed that the assurances he had received from Eisenhower would contribute

to maintaining the political situation in

Tunisia and will permit me to obtain a

progressive amelioration of the state of the indigenous mass. (123)

Murphy thought it had been superfluous for Mast to speak to Eisenhower as though nothing had been done about the Doolittle matter. Nevertheless, when Eisenhower questioned Murphy about the Doolittle problem, Murphy explained it to him as he had already done to Bedell Smith. (124) Both Eisenhower and Bedell Smith insisted that Doolittle not be allowed to return to Tunis. They thought that he was acting against united states policy and that American military concerns in Tunisia were so important that the United States could not risk the trouble with the French that would result if Doolittle continued his activities. Eisenhower requested that a "well balanced and intelligent" (125) replacement be found. In reporting this to the state Department, Murphy concluded by saying that some French who were already unfriendly to the united states were using the Tunisian policy of Doolittle as another example of the "meddling" of the state Department in French affairs and saying that united States policy was designed to diminish the French position in North Africa. (126)

Murphy may have been influenced by Macmillan, who 
in his war Diaries indicated he had had a hand in

Doolittle's recall. Macmillan described himself as an old friend of Mast, whom he had known and liked from Algiers, and who was "very pro-British and reliable." (127) Macmillan had dinner with Mast at the mess in Tunis on July 23 . On July 24 when Bedell Smith came for a talk with Macmillan, the latter expressed his desire to see Doolittle removed "as a source of trouble to the French and of disunity to the Allies." (128) Macmillan had met with Doolittle and formed a bad opinion of him. (129) In view of the fact that he was a friend of Mast and represented a prime minister who had sworn to defend the British Empire this was not surprising. Felix cole, who came at the end of July to Tunisia from Rabat, Morocco to serve as temporary Consul General when Doolittle was recalled, sent a long letter to Murphy about the situation as he found it. After being there only eleven days, he wrote that a change was necessary in the United States Consulate especially in connection with relations with the French. While Doolittle was "an able, intelligent and attractive personality," he had pursued a personal policy which was not in accord "with the general line prescribed. . The consulate has become his personal appanage and the seat of his personal politics." (130) Those toward whom his personal policies were aimed were the leaders of the Tunisian "intelligentsia". They have taken advantage through him, or through his influence on Murphy in Algiers, or the Department in washington to promote their 
goals of obtaining from the French more control over their own affairs and own people. As cole understood it, interfering in the question of Tunisian rights and grievances toward the French was not "the proper concern" (131) of the United States Consulate in Tunisia except to preserve peace and quiet in a military area. Cole noticed a "swarm of visitors at the office" (132) on his first day. A Tunisian, Abdelaziz Hussein, "Slim Driga", was using the kitchen of the Consulate apartment to receive reports of French abuse. This slackened a day or two after cole came partly because Doolittle, before he left, had already told Slim Driga to stop using it. Recently Doolittle and Utter had suspected that he was receiving money by posing as the consul's private secretary and as the only channel by which one could communicate with the Consul General. According to cole he had had police charges in 1937 of "abuse of confidence, embezzlement and bad checks" which may or may not have been because of Neo-Destourian activities. (133)

Mast reported to Algiers that Doolittle's departure had brought about a marked "detente" in the relations with the American Consulate. He had seen cole twice and the latter had expressed his desire to stay out of local intrigues and to have no relations with anti-French Tunisian personalities. Cole gave Mast the impression, by his attitude and words, of having received formal instructions in this regard from Murphy. Some United Nations officers, 
however, persisted in maintaining toward "indigenous elements" a policy similar to that of Doolittle. (134)

Mast continued that rumours had circulated in the Destourian circles that Doolittle was not coming back. Bourguiba appeared discouraged and, according to reliable sources, thought of abandoning politics and of going to Egypt for some time. Mast wrote "I, of course, would not put any obstacles in his way." (135)

On September 14, 1943 Murray wrote Murphy that he had "given much thought to your various communications regarding Hooker Doolittle's policy with respect to the Arabs in Tunisia." (136) Because of Eisenhower's "strong views in this matter," the Department had decided that it would be "inadvisable to have Doolittle remain in Tunis and that he should be transferred to another post." (137) The Department, however, thought it best "for reasons of prestige" (138) for Doolittle to return to Tunis for a short time to wind up his affairs and to receive a transfer in the near future. This would avoid the precedent "of yielding to French pressure" (139) which the United States might regret in the future. Murphy thought Felix Cole and Doolittle might exchange posts with the latter going to Rabat, Morocco.

In Tunisia both cole and Mast now confirmed what Doolittle had been reporting about French treatment of the Tunisians. To save face Mast probably had to wait until Doolittle was no longer on the scene to take measures to correct the situation. Mast now formed a commission to study 
ways of opening up more positions in the administration for Tunisians. A start had been made by appointing a Tunisian to be a counselor in city planning. Since many Tunisian homes were destroyed during the fighting, using a Tunisian to plan the rebuilding could be beneficial. According to cole, while the French realized it was politically desirable to open more positions to Tunisians, it was difficult to find Tunisians who would stay in the bureaucracy. Tunisians usually studied to become either lawyers or physicians. While the latter found jobs as community physicians in the administration, the former did not fit easily into a routine bureaucratic job. (140)

Beginning in August Mast had begun to try to create an atmosphere of confidence and understanding between the French and Tunisians. Utter had obtained a letter from "very confidential sources" (141) that Mast had written to bureau and office heads of the French administration reprimanding them for their behavior toward the Tunisans. About this letter Cole wrote the State Department:

This rebuke to French bureaucratic behavior is unprecedented as far as anyone in this office can remember. Many of the French Government employees, uneasy because of their own conduct during the occupation, have sought to assuage their consciences by taking it out on the Arabs whom they accuse of all the misdeeds of which they themselves were guilty. The inferiority complex which local French officials have consistently shown also explains their attitude of bullying the weaker party. (142)

Mast in his letter asked the Frenchmen "to adopt a 
correct attitude toward Tunisian Moslems by avoiding all contemptuous words or gestures." (143) He reminded them that the French acts were being observed by foreign troops as well "as an educated and cultured Tunisian bourgeoisie and that every blundering and stupid act may endanger the very existence of the Empire." (144)

In October Murray, Adviser on Political Relations, sent Berle a report on native affairs in Morocco written by Gordon Browne, now with the OSS, whom he described as formerly "one of our ace control officers" (145) in that area. Going into the history of the protectorate in Morocco, Browne discussed the present Moroccan situation which was similar to that of the Tunisians. He, also, mentioned that stories had begun to drift into Morocco about the French attitude toward the Tunisians when that country was reoccupied. Murray felt sure that Berle would agree with him that when the views held by such persons as Gordon Browne and Hooker Doolittle became current in the United states, the state Department would be subjected to rather severe criticism for ignoring the Atlantic Charter. The inconsistency of this policy would be pointed out in that the United States was going to great lengths to suppress those principles in North Africa while being concerned about them in India.

Browne's report along with one which Berle had received from the Joint Intelligence Committee of the Army must have made Berle decide it was time the President 
learned of the Doolittle situation. The J.I.C.A. report, drafted by an informant, described how the Tunisians had turned instinctively to Doolittle because of the "massive arrests even of the important Arab families," (147) how Doolittle had intervened several times, how the Tunisians became used to addressing him and deserting the French Residence, and how this had annoyed Mast. The Tunisians had reacted emotionally to the news of Doolittle's recall which had been a real blow to them and especially to Bourguiba. (155)

Berle asked Murray to draw up a one page memorandum for the President. While this was prepared and signed by Acting secretary of state Edward stettinius, a handwritten note attached to it in the Archives indicates that it was "not seen by the President." (149) Probably stettinius did not despatch the memorandum to the President because in the meantime he had arranged a personal meeting between the President and Hooker Doolittle. Stettinius, who was upset by Doolittle's recall, had him stopped in Union station as he was about to leave Washington. In a note to the President he wrote:

You have been interested in the problems of the natives in North Africa. I wonder if you would perhaps care to see Hooker Doolittle, Consui General in Tunis up to a couple of months ago, who, prior to that, spent eleven years in the area; was an eye witness of the French colonial policy in Tunis; got to know too much; was fired out by the French for that reason. The story is dramatic; and really raises the question as to whether we ought to try to mitigate the rigors of the French imperial policy. It is quite a story. (150) 
Stettinius' promise of a good story must have aroused Roosevelt's interest because he agreed to see Doolittle. A meeting was arranged for $11: 15 \mathrm{a} . \mathrm{m}$. on November 9 .

While the President began the interview by asking Doolittle about what he called "the Moors" in Tunisia, the problem was discussed only briefly and superficially. Doolittle told Roosevelt that there had been some relaxation of the actively oppressive measures and that the Resident General had written his subordinates that they were now under observation by foreign forces. When he reported that some steps which he had suggested had been taken, the President said, "Good work." To Doolittle's suggestion that he had interpreted the President's sentiments too early, the President smiled and said, "it seemed so," but he agreed with the idea of acting as a conscience.

The President then questioned Doolittle on a broad range of topics including what sort of person the new Bey was, the reception given de Gaulle in Tunis, how the Arabs got along with the Jews and Italians, and about the food situation. Doolittle responded that the new Bey was an elderly scholar without the influence of the former Bey; that de Gaulle had received a great welcome and was a superb showman; that the Arabs resented the Jews and Italians because of economic competition and because of memories of Italian acts in Libya; and that wheat and olive oil were not moving and would soon create a storage problem. (152) 
"Foreign Service officers could help the Arabs by reporting on their difficulties and asking tactful, but pointed questions." (153) The main problem was lack of contact. Roosevelt was aware of this and mentioned Archie Roosevelt as having been transferred from North Africa because he was too "pro-Arab". Doolittle said he had seen Archie in North Africa and his "pro-Arab" tendencies were similar to his own in merely wishing to see them have decent treatment. The French not only tried to prevent the North Africans from talking with Americans, but from being exposed to American publications. Doolittle showed Roosevelt a copy of the Arabic edition of the Reader's Digest which the French did not permit in North Africa. Roosevelt was surprised and asked why not. Doolittle presumed they did not want to give the "Arabs any food for thought." (154) Doolittle thought it should be made available through United States offices there, "that it would be intellectual manna." (155)

Doolittle concluded that the President was well informed on the whole situation and was especially interested in Morocco. He was also interested in the idea of an international trusteeship. He talked about "the vast Arab majority and seemed to feel that something should be done for them." (156) He noted the difference between Algeria and the Protectorates, Morocco and Tunisia, where he thought a difference in treatment could be brought about. While obviously interested and sympathetic with the plight of the North Africans, Roosevelt did not bring about any policy 
changes. He may, however, have intervened to see that Doolittle was able to return to Tunis eventually to wind up his affairs and help move his wife and household to Egypt. (157)

The State Department must have "yielded to French pressure" after all because Doolittle did not return to Tunis until after he had assumed his new post in Alexandria, Egypt. The fact that he went there before returning to Tunisia and was not given the position in Rabat was probably due to another intervention by Mast. Four days before Doolittle's interview with Roosevelt, Mast cabled the French Committee that Doolittle was about to resume his post and he thought Ambassador Henri Hoppenot, the accredited representative of the committee, should make an energetic intervention in

Washington based on promises made by Murphy and Eisenhower. Destourian circles are talking of Doolittle whom they considered as their protector and their best agent. Mrs. Doolittle who is in Tunis is not unfamiliar with these rumours. (158)

Apparently Mast thought of the Doolittles as engaged in something of a conspiracy.

In an undated essay entitled "L'Affaire Doolittle", written on stationary of the Division of Political studies, Doolittle with a certain amount of bitterness, wrote of the power the American Army exercised in dictating what State Department personnel should remain or not in North Africa. Doolittle said the iceas of the state Department, regarding 
its personnel in North Africa, did not appear to be worthy of consideration since

General Mast continues to dictate the movements of personnel in that area apparently on the grounds that he is the only friend still left to the American Army there. (159)

Doolittle thought it was regrettable that the Army was isolated. However, he continued, no effort had been made to determine the reason. Possibly it was due to ignoring the wishes of the majority so as to keep the "professed esteem of certain agreeable individuals." (160) By this Doolittle probably meant people with whom Murphy had been working, such as Mast, as well as those who were holdovers from the Vichy regime.

It was alleged that Doolittle had intervened in the internal affairs of Tunisia. Doolittle asked if any specific charge had been filed to this effect. The internal situation was said to have improved since the intervention stopped. "Has the fact been mentioned that certain measures suggested by Doolittle to the French prior to his departure have been put into effect and may have something to do with better Arab-French relations." (161) If the French treated the Tunisians in such a way as to cause "resentment against not only themselves but also against American forces," it would seem obvious that the United states should try to persuade the French to adopt a policy that would tend to "conciliate local majorities." (162)

The worst aspect of the intervention by the United States Army in this situation was that, by relinquishing the 
position of the state Department, "we give up any moral influence we may have and with it the hope of implementing any of our ideas regarding the betterment of colonial peoples throughout not only French colonies but throughout the world." (163)

If United States policy was to be determined by

the personal social relations of colonial administrators with American army officers who happen to be stationed in certain areas, the work of the Division of Political studies seemed useless and henceforth the United States should simply approve in advance the policies of the subordinate officers in the colonies occupied by American forces. (164)

Doolittle's daughter, Katya Coon, said her father was very depressed when he returned to the United States, fearing that his career was finished with the state Department. It was her belief that it was due to the intervention of Roosevelt that he was reinstated. (165) Still it was Mast and the American Army that had the final word. Roosevelt may have been preoccupied with other problems for it was at this time, November 1943, that de Gaulle forced Giraud out as chairman of the National Committee, and it was in November that de Gaulle had taken repressive measures against the nationalists in Lebanon, which Roosevelt had not liked. In this case, even if he had wanted to intervene, Roosevelt may have found himself in a difficult spot since his personal representative, Robert Murphy, was supporting the French position of asking for Doolittle's recall. Roosevelt probably did not wish to 
overrule him. Nor would he have wished to overrule the decision of the Supreme Commander, Eisenhower. The latter had probably been persuaded by Mast's argument that Doolittle's presence interfered in the war effort. Even if he were not persuaded, his policy from the first was that he needed the French and had to have their cooperation.

Eisenhower revealed the reasons for this policy in a letter he wrote to his brother Milton on June 29, 1943 just a month before Doolittle's recall in which he said that there was

deplorable racial and political discrimination that not only cried aloud for quick correction, but were of the type that our people were determined that war should eliminate. (166)

Nevertheless it was necessary to have the

active cooperation of French forces. If we had not we would have had to permit the Axis to take over and defend Tunisia. If we had done that we would be fighting the Tunisian campaign until next Christmas. The size of the eventual military victory certainly justified the policy of evolution rather than revolution in the political field. (167)

While Eisenhower's policy was understandable, Murphy's was not. Eisenhower, after all, did acknowledge the "deplorable" conditions of the North Africans. Murphy, on the other hand, chose to ignore them. Although Doolittle had aroused the sympathy for the Tunisians of members of the State Department in Washington such as Murray, Berle and Stettinius, he had not influenced Murphy who was in a position to talk to the French. When Giraud asked Murphy what American opinion would be if the French deposed the 
Bey, Murphy could have pointed out that the American Consul General considered it a mistake. It might have saved the French from a move which later many of them acknowledged to be a mistake. Instead Murphy told Giraud what he wanted to hear, that it was a French problem as long as it didn't interfere with the war effort. It would seem that Macmillan was right when he said about Murphy:
He is a pleasant enough creature and amenable to kind and firm treatment but he had neither principles nor judgment. (168) He is without fixed purpose or plan and is affected by every changing mood of local opinion or washington rumour. (169)

If Macmillan's assessment is correct, then one can better understand why Murphy ignored Doolittle's strenous efforts to have United States policy in Tunisia reflect the principles of the Atlantic Charter and was swayed by the French.

The choice of Marcel Malige as Doolittle's replacement was a clear indication that the policy of appeasing the French had prevailed. French Ambassador Hoppenot cabled Mast that he had the best reports about the new Consul General to Tunisia, Marcel Malige, whose parents were both French, and who had always shown a sympathetic understanding of French interests. Malige, who had been consul in Martinique, had a "favorable prejudice toward Petain and for certain aspects of the National Revolution" (170), according to Hoppenot, while he was only lukewarm toward de Gaulle. In his wire Hoppenot said, "It's 
a choice about which we can only be happy." (171) 
NOTES

CHAPTER VII

1. Doolittle to Hull, December 30, 1942.

2. OSS Report No. 0136.

3. Albert Memmi, La Statue de Sel (Paris: Gallimard, $1966), 294-295$.

4. Ibid, 296-297.

5. Paul White to Morgenthau, June 23, 1943, Morgenthau Diary, container 644, deposited at the Roosevelt Library, Hyde Park, New York, 225.

6. Morgenthau to White, November 3, 1943, Morgenthau Diary, container 688 , part 1,9 .

7. White to Morgenthau, December 14, 1943, Morgenthau Diary, container 688 , part 2,24 .

8. OSS Report No. 38992.

9. Memmi, La Statue de Sel, 296.

10. Doolittle to Hull, June 1, 1943, 851S.00/259.

11. Doolittle to Hull, June 3, 1943, 851S.00/257.

12. Doolittle to Hull, June 2, 1943, 851S.00/256.

13. Doolittle to Hull, February 10, 1943, 851S.00/242.

14. Ibid.

15. Ibia.

16. Doolittle to Hull, April 17, 1943, 851S.00/247.

17. Ibid.

18. Ibia. 
19. Ibid.

20. Doolittle to Hull, June 1, 1943, 851s.00/255.

21. Doolittle to Hull, January $8,1943,8515.00 / 238$.

22. Ibid.

23. Ibid.

24. Telegram from Marchal to France Libre in London, April 14, 1943, vol. 861, Quai d'Orsay.

25. "La Question Tunisienne," vol. 861, Quai d'Orsay.

26. Ibid.

27. Doolittle to Hull, April 17, 1943, 8515.00/247.

28. Ibid.

29. Ibid.

30. Murphy to Doolittle, April 22, 1943, 851s.00/259.

31. Ibid.

32. Doolittle to Murphy, May 3, 1943,851S.00/259.

33. Ibid.

34. Ibid.

35. Alphonse Juin, Mémoires: Alger, Tunis, Rome (Paris: Librairie Artheme Fayard, 1959-60), 181.

36. Ibid, 178 .

37. Ibid, 179 .

38. Ibid.

39. Doolittle to Hull, May 14, 1943.

40. Ibid.

41. Interview with Katya Coon, December 10, 1983, Marshfield, Massachusetts.

42. Murphy to the President and Hul1, May 14, 1943, $851 \mathrm{~S} .00 / 250$.

43. Ibia. 
44. Ibid.

45. Ibid.

46. Ibid.

47. Juin, Mémoires, 183.

48. Ibid, 188 .

49. Ibid.

50. OSS Report No. 001826, June 18, 1943.

51. Charles-André Julien, L'Afrique du Nord en Marche (Paris: Rene Julliard, 1972), 92.

52. Ibid, 156.

53. Ibid, 153 .

54. "Le Président Bourguiba Retrace Les Événements du 7 Juin 1943," Radio Interview printed in La Dépeche Tunisienne, June 8, 1960, Katya Coon.

55. Ibid.

56. Juin, Mémoires, 192.

57. Doolittle to Hull, June 1, 1943, 8515.00/259.

58. Ibid.

59. Ibid.

60. "Le President Bourguiba Retrace Les Evénements du 7 Juin 1943," June 8, 1960.

61. Ibid.

62. Doolittle to Hull, June 1, 1943,8515.00/255.

63. Ibid.

64. Ibid.

65. Ibid.

66. Doolittle to Hull, June 1, 1943,8515.00/259.

67. Ibià.

68. Ibid. 
69. Ibid.

70. Ibid.

71. Ibid.

72. Ibid.

73. Ibia.

74. Ibid.

75. Ibid.

76. Ibia.

77. Doolittle to Hull, June 5, 1943, 851S.00/253.

78. Ibid.

79. Ibid.

80. Bourguiba to Roosevelt, transmitted by Doolittle to Hull, June 7, 1943, Katya Coon.

81. Ibid.

82. Ibia.

83. "Bourguiba et Doolittle," L'Action, June 5, 1966, Katya Coon.

84. Doolittle to Hull, June 11, 1943, 851S.00/262.

85. Ibid.

86. Juin, Mémoires, 193.

87. Ibia.

88. Ibid.

89. Mast to Massigli, June 27, 1943, vol. 909, Quai d'orsay.

90. De Gaulle, Mémoires de Guerre: L'Unité, 123-124.

91. Shortly before the United Nations retook Tunisia, Esteva was deported by the Germans, apparently forcibly. When he reached Vichy, he was given special honors for his actions during the occupation. (Cole to Hull, october 2, 1943, 851S.00/285) Later when France was retaken and was under de Gaulle's authority, Esteva was tried by the High court and sentenced to solitary confinement. (De Gaulle, 
Mémoires de Guerre: Le Salut, 110)

92. Ibia.

93. Dallek, Franklin D. Roosevelt and American Foreign Policy $1932-1945,458$.

94. Juin to Giraud, May 28, 1943, Quai d'Orsay.

95. Murphy to Hul1, June 16, 1943, 8515.00/258.

96. Ibid.

97. Ibid.

98. Ibia.

99. Ibid.

100. Murphy to Hull, June 26, 1943, 851S.00/263; June $28,1943,8515.00 / 264$.

101. Murphy to Murray, August 11, 1943, 8515.00/279.

102. Murphy to Hull, June 26, 1943,8515.00/263.

103. Ibid.

104. Murphy to Alling, July 5, 1943, 8515.001/34.

105. Ibid.

106. Ibid.

107. Murray to Berle, July 26, 1943, 8515.00/257.

108. Ibia.

109. Ibid.

110. Ibia.

111. Ibia.

112. Ibid.

113. Ibid.

114. Berle to Murray, July 30, 1943, 8515.00/257.

115. Ibid.

116. Ibia. 
117. Murphy to Murray, July 29, 1943, 8515.00/267.

118. Ibid.

119. Ibid.

120. Mast to Massigli, August 2, 1943, Guerre 1939-1945, Alger, vol. 868, 4-0-6, Quai d'Orsay.

121. Ibid.

122. Ibid.

123. Ibid.

124. Murphy to Felix Cole, August 5, 1943, 851 S. $00 / 281$.

125. Ibia.

126. Murphy to Murray, July 3, 1943, 8515.00/268.

127. Macmillan, War Diaries, 149.

128. Ibid, 162 .

129. Ibid, 134.

130. Cole to Murphy, August 4, 1943, 8515.00/281.

131. Ibid.

132. Ibid.

133. Ibid.

134. Mast to Massigli, August 10, 1943, vol. 868.

135. Ibid.

136. Murray to Murphy, September 14, 1945, $8515.00 / 279$.

137. Ibid.

138. Ibid.

139. Ibid.

140. Cole to Hull, October 16, 1943, 8515.00/290.

141. Cole to Hull, October 19, 1943, 851s.00/291. 142. Ibid. 
143. Ibid.

144. Ibia.

145. Murray to Berie, October 11, 1943,881.00/2678.

146. Ibia.

147. Berle to Murray, October 12, 1943, 881.00/2680.

148. Ibid.

149. Memorandum to the President, November 1, 1943, State Department.

150. Memorandum to the President, undated, unnumbered, State Department.

151. Interview with President Roosevelt, November 9, $1943,8515.00 / 2821 / 2$.

152. Ibid.

153. Ibid.

154. Ibid.

155. Ibid.

156. Ibid.

157. Ibid.

158. Mast to the French Committee, November 5, 1943, vol. 868, Quai d'orsay.

159. "L'Affaire Doolittle," undated, Katya Coon.

160. Ibid.

161. Ibid.

162. Ibid.

163. Ibid.

164. Ibid.

165. Interview with Katya coon.

166. Eisenhower Papers, II, 1219.

167. Ibid. 
168. Macmillan, War Diaries, 393.

169. Ibid, 66 .

170. Hoppenot to Mast, Decemiver 20, 1943, vol. 868., Quai d'orsay.

171. Ibid, December 18, 1943. 
Chapter VIII

TUNISIA AFTER DOOLITTLE

Marcel Malige came to Tunis as the American Consul General in January 1944 and stayed approximately one year. His appointment was obviously meant to appease the French, and it must have done just that. His sympathies were in harmony with theirs, and he followed a policy of non-involvement with the nationalists. The American Consulate was across the street from the Residency and he came to know both General and Madame Mast well since he was often their guest. Because of his friendship and close contact with Mast, Malige viewed Tunisia very much as the French would have liked the Americans to view it - a country where French and Tunisian lived in harmony.

Malige seriously underestimated the force of nationalism and thought that American observers had exaggerated the importance of the Destour. Malige thought the Tunisians, for the most part, were "apathetic to any change at all because of innate fatalism and non-combativeness." (1) of course, the Destour were quiet the year Malige was there because they were following Bourguiba's manifesto of May 1943 of forming a bloc with the French for the sake of winning the war. Malige did admit 
that there were those who wanted more Tunisians in the administration.

It is true that a few agitators, such as Bourguiba, are genuinely imbued with a desire to see Tunisia governed by more Arabs and less Frenchmen with a view to eventual elimination of the latter: but they have recently confirmed Bourguiba's appeal of as long ago as May 1943 calling upon the Tunisian Arabs to collaborate with the French. (2)

The fact that Malige referred to Bourguiba as an "agitator" indicated his identification with the French point of view. Because of Malige's policy of non-involvement with the nationalists, he was probably out of touch with their true strength. Instead he thought that the "initial enthusiasm among the Destourians over the Atlantic Charter had disappeared," (3) and they had had to accept reality. They had "resigned themselves to gradual political evolution within the framework of a more enlightened French policy." (4) By this remark Malige himself seemed to deny the validity of the Atlantic Charter for the Tunisians, agreeing instead with Mast's basic belief that Tunisia belonged to the French Empire and that this situation was irrevocable.

During this period, Mast continued to restore French authority, on the one hand, by forcibly eliminating any threats to it and, on the other, by gaining the goodwill of the Tunisians, or as de Gaulle wrote in his Mémoires de Guerre, "Resident General Mast maneuvered readily between plans for reform and authoritative action."(5) While it was 
not until 1945 that mast announced his plan for long range reforms, he made many gestures during 1944 to obtain Tunisian good will. At his request de Gaulle paraoned thirty-three Tunisians who had been in prison since 1938 for crimes committed during the Destourian riots of that time. The Residency announced this action as an indication of its desire for "Franco-Tunisian appeasement and frank collaboration." (6) At the same time he launched the Paysannat Plan at Kairouan whereby he presented 350 title deeds to Tunisian peasants who already occupied the land as squatters. In his speech there, he emphasized that "France always keeps her promises." (7) Mast tried to form a commission composed of French and Tunisians to study reforms and took many good will trips to outlying areas. As Mast told Malige, he hoped to do for Tunisia what Marshal Lyautey had done for Morocco. By his reforms and goodwill trips Mast also hoped to nullify the Neo-Destourian demands. As for nationalist demands, he refused to concede to their wish for liberty of party organization and freedom of expression. While he aspired to be an enlightened administrator, as Malige considered him, Mast was very much imbued with the idea of Empire as he revealed in an interview with the Paris newspaper Liberation in November 1944. In his interview Mast spoke of a wish to create "a patriotism of empire." (8) Each country of the Empire would have its own individuality and be governed with the assistance of its elite - including the elite among the 
Tunisians. The independence movement would fail because the improvements planned by the French "will give sufficient liberty." (8) He referred to hopes of the Tunisians raised by the war; "certain Tunisian illusions, of which some remain." (10) Nevertheless, Mast thought there was a favorable attitude "among the native masses" toward France. "The influence of the former Destourian Party is no longer to be feared. They are divorced from the people." (12)

Mast continued that to counteract those "perspectives of independence" (13) held out to the indigenous people in the Atlantic Charter, Tunisia would need the help of England or the United States. England was loyal as well as the United States to the French position. Right after liberation
Tunisian Arab agitators believed they found encouragement in the attitude of the American Consul General, Mr. Doolittle. My personal position allowed me to breast the current. Mr. Doolittle departed. The comportment of the present Consul General cannot lead to confusion and the Tunisians know there is no divergence of views to exploit. The most effective agitator of the past has sought contact, but he struck a categorical refusal. (14)

Mast told Malige that the author of the Liberation story had obtained the reference to Doolittle elsewhere, but, in general, the article reflected accurately enough present French policy toward the Tunisians. (15)

In the article Mast referred to the "former Destourian Party." In October 1943 the French Committee of National Liberation had decided that the "indigenous party" could not be authorized, it having already been banned since 1938. However, Tunisians could join French parties. The 
"agitator" undoubtedly referred to Bourguiba.

The French were not all happy with Mast's reform plans. Some of them thought that instead of giving Tunisians land to cultivate, they should be taught to increase production. Mast, however, realized the settlers had to relinquish some privileges. He thought that giving labor an honorable status could not hurt the real interests of the French. In his interview with Liberation Mast said that with the French settlers the war had brought about the fear of losing everything which was then manifesting itself in a determination "to regain all former privileges - even the most unjust perhaps." (16)

Mast's trips to outlying areas gave him the opportunity to act the part of the benevolent colonial administrator. Even Malige realized that they were so carefully staged that it was hard to judge true native sentiment. These trips, on which Madame Mast accompanied Mast and occupied herself with charitable works, were given much publicity. Mast often asked the American and British consuls to accompany him. This had the effect of reinforcing the French position. In fact on one trip the Bey went with him to quiet rumours that there were differences between the two.

Very shortly after Malige arrived, he accompanied General Mast on a goodwill trip to northwest Tunisia. Writing about this trip and others, Malige portrayed a Tunisia that was living comfortably with the French 
administration. Malige described how at the towns they visited the French and the native leaders made speeches, all claiming loyalty to France, after which Mast would give each of the native officials an autographed photograph of himself. (17)

On the first trip they stayed overnight with a colonialist who had left a practice as an architect in Paris to restore a wheat farm to its productivity of Caesar's time. This meant restoration of underground tunnels which pumped water to the surface and, as Malige wrote, was an example of France's "mission civilizatrice". (18) On this farm the owner had built new concrete living quarters for the Tunisians to replace their sod huts, but the latter still preferred sleeping in their clothes directly on the floor. A future step for the owner in the civilizing process would be to raise the sleeping surface a few inches onto a bed. Malige wrote:

This recalcitrance to first steps in civilization characterizes two-thirds of the population of Tunisia and reminds one of the American Indian's aversion to our own early efforts to help him. (19)

Malige found Mast interested in the material welfare of the Tunisians. Malige reported that there was a serious lack of cloth "and natives in the more remote areas. - .are so clothed in rags as to arouse pity." (20) General Mast promised to have a small amount of clothes sent including discarded American Army clothing. Madame Mast, on one trip, took clothing to the people in the area, while in Tunis she 
organized a charitable sale of articles of clothing. (21) Malige did say that the receptions at the various towns that Mast visited had been organized well in advance by the controllers. While Malige had "an opportunity to talk freely with the native leaders, it was difficult to assess how faithfully the reception portrayed native sentiment towards the French." (22) Malige, however, believed that French influence had not suffered much due to the war "and that sentiment in favor of France's recovery through Allied victory was genuine." (23) Goodwill toward France had been built up by French doctors and nurses. Malige wrote that anti-French sentiment was found mainly in Tunis among a few thousand educated youth and in a few other towns. Actually Malige found little interest in politics outside of Tunis and three or four other cities. In fact he said, what went on in Tunis was looked upon with distrust. One caid told Malige that all natives realized the ascendancy of the Protecting Power, but "only the malevolently disposed criticized the relationship." (24) The Tunisians were indifferent to who occupied the Beylical throne so long as the French upheld it. (25)

In the south a caid told Malige they respected the Bey because of the French and, if the Protectorate were eliminated, they would go back to independent tribal ways. In the north around Sfax, Arabized descendants of Phoenicians were distrustful of Arabized Berbers. Both 
wanted the French to stay as arbiters between them and as caretakers of order. (26)

Reporting on a study trip to central and southern Tunisia, Malige described the controller-caid relationship. There were twenty-four French civil controllers and thirty-six Tunisian caids who governed 2,500,000 Tunisians. Six of the controllers were chiefs of six regions with the other eighteen under them. Each controller had a district with usually two or more caids to control. The essence of the French Protectorate was this co-sovereignty. (27)

Malige was impressed that "the controllers were of uniformly high standard." (28) He thought their job required much tact "in teaching the Caids to carry out their responsibilities to the governed along western standards." (29) On the other hand the caids had punitive powers which led to "venality that characterized the native officials". (30) Graft was not considered immoral by the Tunisians because it was an "ingrained practice consolidated by many centuries." (31) According to Malige,

all Controllers and Caids agree that the universal Moslem trait of deception carried to the point of perjury is their greatest problem, one they despair of ever solving. (32)

The checks and balances made the system "function among a people who are fundamentally undisciplined by nature." (33)

One of the cities where anti-French sentiment was found was Moknine where the first attack against French 
authority was made in 1938. Representatives of both the British and American Consulates were invited to accompany Mast on a trip there. John Utter went along. Utter reported that in his speech there, "realizing that he was among the enemy, so to speak, Mast spoke less in generalities and devoted much of his speech to subjects which touched the inhabitants of his region." (34) Mast told Utter he had purposely come to Moknine to "beard the lion in his den." (35) By putting into effect that for which the Destourians were agitating, the new French policy was, according to Mast, taking the initiative away from Bourguiba and his followers. (36)

When Utter asked Mast why he didn't give Bourguiba a place in the administration, Mast replied "that Bourguiba would have too much to lose in abandoning his party - both in prestige and income." (37) Utter also asked Mast how "the exploratory conversations by Tunisians for reforms were progressing." (38) When Mast answered that "nothing was being accomplished so far and prospects were poor," (39) it confirmed what Utter had already heard.

Utter was referring to the commission Mast was trying to form of twelve Tunisians and twelve French to study reforms. Bourguiba refused to join the commission unless the ban on the Neo-Destourian Party was lifted. Other Tunisians had also declined. In October, however, Mast was able to induce Tahar ben Amar, the head of the Tunisian section of the Grand Conseil, the legislature, to bring together 
seventeen leading Tunisians, including Bourguiba, to seek agreement on political aspirations preparatory to appointing twelve of them to the Franco-Tunisian Commission. When they met, they voted against participation in the commission unless liberty of expression, party organization and meeting were restored. They also wanted seven of the Tunisians at the meeting to be designated as an exclusively Tunisian committee which would reflect the different Tunisian political views. These seven would decide on a program for eventual presentation to the French government rather than the Resident General's commission. Mast refused and esplained to Malige that bitter experience with sabotage and bloodshed in 1934 and 1938, when the Tunisians had Iiberty of organization, precluded restoration of the liberty asked for by the Tunisians. (40)

Mast, in trying to form his commission, had brought the Tunisians together. They had settled their differences and were presenting a united front to the French. The Tunisian Committee of Seven in November voted in favor of self-government with a prime minister who would be responsible to a popularly elected assembly. France would remain the protecting Power. These views would be submitted to other leading Tunisians before being adopted as the Tunisian nationalist platform. Mast, however, considered the resolution impolitic at a time when solidarity with France was important. Receiving this decision, the committee voted to do nothing. (41) 
Bourguiba, who had resumed his law practice, had advised his followers to be patient and to cooperate with the French in their stated policy of appeasement of the native population. In March 1944 Mast reported to Algiers that Bourguiba was in semi-retirement and nationalist activities were confined to "court intrigues and clan rivalries." (42) According to Mast, Bourguiba's policy appeared to be one of "playing the French card." (43) Mast went on to say that Bourguiba was beginning to be criticized for his policy of "attentisme" and his desire for a rapprochement with France. Mast thought that the former Bey, Moncef, had supplanted Bourguiba in the spirits of the bourgeois and the more educated. "The star of the chief of the Neo-Destour had seemed to pale," and he was already considered "un vieux" by the young ambitious

Destourians. (44)

In fact some Tunisians even accused Bourguiba of having been bought by the French. Some of his lieutenants, including Salah ben Youssef, considered the most important Neo-Destourian leader after Bourguiba, had wanted more political activity and had wanted to distance themselves from Bourguiba. Bourguiba, however, had brought them back into line and in August 1944 the party had issued another manifesto justifying the apparent inactivity.

In spite of Bourguiba's cooperative position, Mast, who met with Bourguiba in August 1944 and asked what he wanted, refused his request to print an unmuzzled party 
organ and to hold a party congress of four hundred delegates at which the reinstatement of Moncef and Tunisian

independence would be discussed. Mast told Bourguiba there was no real political unrest in the regency. (47) In fact from the summer of 1944 Mast restricted Bourguiba's movements more and more. In the summer of 1944 a bad food shortage, resulting in heavy French requisitions, had added to native unhappiness. Mast must have feared that there was a risk in allowing Bourguiba to circulate freely. Even though Bourguiba repeatedly tried to reach an understanding with the Residency and attempted to convince Mast that his policy would only add more troubles, he was "brushed off" and put in a situation equivalent to forced residence. Discouraged by Mast's intransigence, Bourguiba decided that the French were not going to make any concessions and only in obtaining help from the outside could pressure be put on the French to grant the reforms they refused to give spontaneously. His hopes as well as those of the other Neo-Destourians turned toward the Arab League. In the fall of 1944 he sought help from both the American and British consuls to intercede with Mast to allow him to leave for a pan-Arab conference in Cairo.

Pan-Arabism had been a negligible force in Tunisia, but Tunisians had been made aware of it in 1943 when Feisal and Khaled, the two sons of King Abd al-Aziz Ibn Saud of Saudi Arabia visited Tunis. When they left, the Bey sent a letter to the king in which he expressed the hope that his 
majesty would find success in the idea of a union of the Arab world which would be the "reward for his noble and glorious initiative in striving to help Arab states... out of the sometimes painful straits in which certain ones among them still find themselves." (48)

Bourguiba approached Malige to ask him to intercede with Mast for permission to go to a pan-Arab conference in Egypt despite, according to Malige, "previous failures to involve me in Destourian questions." (49) Malige agreed to see him, having first made sure that Mast had received him. Though the meeting had been scheduled at one o'clock for a half hour, Malige found Bourguiba so interesting that he kept him all afternoon. The two men found that they were both graduates of L'Institute d'Etudes Politiques in Paris, having attended together in 1926-1928, though not having met. (50) In spite of his interest in Bourguiba, Malige refused to help him leave Tunisia by interceding with Mast, and he refused to see him on another occasion when Bourguiba wanted to see him "ostensibly to air Nationalist resentment over continued denial of the right of self-expression." Malige thought it was possible he wanted to see him to "strengthen his own position among the party leaders." (52)

The Communists were taking advantage of the inactivity of the Neo-Destour and at times Mast seemed more worried about them than the Destourians. After the United Nations liberation some Neo-Destourians had joined the 
Communist party with the idea of using membership as a way of criticizing French policy not allowed them as nationalists. The communists trying to enlarge their numbers had taken on the political goals of the Destourians as well as keeping the goals for social change of their own party. In September 1943 Mast put the Secretary General of the Communist party in jail for sending him a letter in which he strongly criticized Mast's Tunisian and economic policies, charging that the situation had become worse than during the German occupation. In october 1943 Mast reported to Algiers that Communist propaganda could have a disastrous effect on the Tunisians who were unbalanced by the enemy occupation. The Communists could cause serious social troubles which could gravely hurt the war and the French position in Tunisia. Mast wanted the Committee to limit Communist Party membership to French citizens. (53)

Mast called on Macmillan in Algiers in October 1943 to express his concerns about the communists who were working hard with the Tunisians and "stirring up disaffection." (54) Mast complained to Macmillan that he couldn't get support from the French Committee in Algiers for firm measures against the Communists because de Gaulle was "always flirting with Russia and Communists." (55) Macmillan, describing this meeting in his war Diaries, wrote: "But poor Mast is rather a 'fusser', and apt to exaggerate on this topic." (56) Macmillan told him he should get Stalin to intervene and tell the Communists to be quiet 
as they were interfering with the war effort. When Mast "brightened up" at that idea, Macmillan promised to put him in touch with the new Russian Ambassador. (57)

By January 1944, however, Mast found the Destourians were the most troublesome party. By then the Communists had separated from the Destour because, they claimed, the Destourians were taking up anti-French activity. For their part, the Destourians were upset with the Communists for their pro-French position and in March 1944, when the Communists publically stated their platform which included a pledge of cooperation with the Protectorate, the Destourians walked out. Ben Youssef, who thought there were several thousand Tunisian Communists, told the American vice-consul, Paul O'Neill, that this stance would not change as long as the Communists went along with the French. He did say that, if the communist Party came out wholeheartedly against France in Tunisia, he would become a communist immediately along with all other Destourians. O'Neill commented that this statement showed how bitterly anti-French and opportunistic some of the more militant nationalists were. (58)

Less militant Destourians looked upon the Communists as adversaries. They worried about their recruiting of Tunisians. According to Mast, the Communists tried to win the Tunisian population over to their side by flattering them in their sentiments for the former Bey, by showing that Islam was compatible with Bolshevism, in attacking the 
established order, the bureaucrats, and in particular the government, and in exploiting economic difficulties, notably that of provisioning. (59)

The concern of the nationalists was expressed in an editorial in the Arabic Nahda, which Malige described as much a nationalist organ as was possible under the Destourian ban. It stated, "We are Moslem Arabs; we have our own ideals and traditions: we want none other." (60) Malige commented that the permission of the Residency to print the editorial reflected its dislike of both communists and Destourians. According to Malige, Mast welcomed the controversy between the two believing it created for him "a divide-and-rule atmosphere." (61)

At the time of the death of Shaikh Taalbi, the head of the old Destourians, in October 1944 a bad rift occurred between the Communists and Destourians. The latter were furious over the obituary of Shaikh Taalbi in the local Communist Party organ. It was written by its leader, a Tunisian, who referred to the old Destourians as pro-fascists and suggested Taalbi was a Hitler sympathizer and that he had consented to the collaboration of his political associates with the Axis occupation. Bourguiba told Malige that the Destourians "were already lukewarm to the Communists, because the latter were too pro-French and this latest attack has split them wide apart."

Both the American and British consuls agreed not to attend the funeral. In Malige's case it was probably because 
of his non-involvement with the nationalists. When Bourguiba did not attend Shaikh Taalbi's funeral, it was feared that he had left for the Pan-Arab Conference. Mast had asked both the British and American consuls to prevent any escape of Tunisian leaders via United Nations military aircraft. Actually Bourguiba had not gone. (63)

While there was little political activity among the Tunisian nationalists during 1944, significant changes occurred in the French Committee of National Liberation. In April 1944 de Gaulle relieved Giraud of his rank as commander-in-chief thereby essentially eliminating Giraud from the scene. Roosevelt continued to be opposed to recognition of de Gaulle in spite of the fact that the invasion of France was imminent and Eisenhower and Murphy recommended recognition in order to have a French administration in place with which to deal after the invasion. Henry Stimson blamed Roosevelt's opposition on Leahy, who had warned the President that he might expect a revolution in France. Although Leahy had had the advantage of being stationed in vichy for several years, stimson did not think his advice was good. He did not consider Leahy "a very acute person." (64)

on May 7 de Gaulle visited Tunis in celebration of the anniversary of the United Nations victory there. In a speech he spoke of the need for recognition.

On the eve of battle in France, we ardently wish that French realities be definitely recognized, so that the Allied armies can concentrate on their task, which must remain 
strategical. (65)

On June 6 the United Nations invasion of Normandy took place, and though there was no revolution, Roosevelt still refused recognition.

In June Mast expressed some bitterness to Malige over the "mistaken" Unitea States policy of non-recognition of de Gaulle. He spoke of an anti-American sentiment that was developing because of it. Mast was now pro-de Gaulle, not from personal attachment, because his sympathies were with Giraud, but because of the political leadership of de Gaulle, which he considered the best rallying point for Frenchmen under the circumstances. (66)

Mast told Malige that the proclamation of General Eisenhower (the Darlan deal) had been expedient, dealing with officials found on the spot. They were, however, "Vichy tainted." Mast continued that, "Just as Darlan had been eliminated from the Algiers scene so would any other rival of de Gaulle" (67) who might arise under American aegis. No French prefect could govern his department without a superior and central French authority.

Mast attributed United States policy to the unsympathetic reaction Roosevelt had at his one meeting at Casablanca with de Gaulle. He thought other meetings would have changed the reaction. Besides, he thought personalities should be overlooked. Mast felt deeply over what he felt to be the misguided policy of the united states. Malige had observed the same belief in the press and in conversations 
with other Frenchmen. (68)

Actually President Roosevelt had invited de Gaulle to meet with him in July 1944, the following month, but Mast had heard that "the President's invitation was 'to have tea' and nothing was expected from it." (69) Mast was right because, when Roosevelt met with de Gaulle in Washington, he refused to grant any concessions to de Gaulle's Committee other than "temporary de facto authority" for civil administration in France, on condition that military authority rest with Eisenhower and that the French people would choose their own government. (70) While Paris was liberated from the Axis on August 25 and the Committee moved from Algiers to Paris, it was not until October 1944 that Roosevelt gave his approval of recognition which was announced on October 23. Shortly after that Mast held a reception to commemorate recognition by the United States and Great Britain at which he reminded Malige of his "outburst" of June. Malige and Mast agreed that frankness was the best policy among friends. (71)

When Malige was transferred to another post in Poland during the early part of 1945, Vice-Consul Paul O'Neill took over as acting Consul General. He had arrived in Tunis at the end of August 1943. At that time he had only just become a Foreign Service officer. Having been sent briefly to Canada, he had requested a post as close to the war zone as possible. Though from a Quaker family, both his brothers were in the armed forces, and he, himself, was not opposed 
to fighting. Still, because he was married and had a child, he was exempt. (72)

O'Neill had met Doolittle when the latter came to Tunis for three weeks to pack up his things. O'Neill admired him though he felt he had gone too far in his pro-nationalist position. O'Neill found that Malige was pro-French with a hands-off attitude towards the nationalists. Though the latter had sought out O'Neill, he was less involved with the political side while Malige was there. It was John utter who saw the nationalists and who was much more understanding of their aims than Malige. Utter, however, left Tunis for an assignment in Paris in February 1945. (73)

In that month O'Neill wrote of the reaction in French government circles to a speech made on February 4 by de Gaulle in Paris. Roosevelt had not wanted de Gaulle at the Yalta conference and rejected the latter's request to attend. Regarding France as a defeated and collaborating power, Roosevelt did not think France deserved to have an equal role in making postwar decisions. Nor did he want to add to de Gaulie's power by giving him a voice in these decisions. De Gaulle, on the other hand, wanted to assert a position for France as a victor power with equal authority. His exclusion from the conference had led to hurt feelings among the French. For those with whom O'Neill had spoken, the part in de Gaulle's speech which brought forth the most pride was the one saying that, in the future peace, France 
would not consider herself bound by anything which she had not discussed and approved in the same way as the other powers. (74)

By the time of Yalta Roosevelt had accepted the idea that France would play a stronger role in Europe than he had previously wanted. Because he did not think the United States public would agree to keeping occupation troops in Germany more than two years, he decided at Yalta to give France an occupation zone and to let France arm eight more divisions. By Yalta Roosevelt had also given up the idea of putting former French possessions under trusteeship except for Indochina and by March he would agree to make that country a trust territory of France. (75)

Roosevelt asked de Gaulle to meet with him in Algiers after the Yalta conference. De Gaulle refused feeling that, if Roosevelt had a good reason to see him, he should have permitted him to go to Yalta. Furthermore, de Gaulle did not think the American President qualified "to invite the French President to visit him in France." (76) De Gaulle realized that for Roosevelt, Algiers probably was not France, but de Gaulle felt it was just as well to remind him. Besides, Roosevelt was starting his trip by going through Middle Eastern Arab states inviting kings and heads of states aboard his cruiser including the presidents of Syria and Lebanon, French mandates. De Gaulle considered it an affront that the President was offering to receive de Gaulle "on the same ship and under the same conditions." (77) Thus, at the 
time of Roosevelt's death on April 12, 1945, relations between the two men had not improved, and this fact undoubtedly had an effect on future united states relations with France.

When O'Neill took over as acting Consul General his despatches were far more concerned with the Neo-Destourians than Malige's had been, indicating, no doubt, more contact with them. Nationalist activity was still relatively dormant. The nationalists were aware that they could expect no backing at this time from Great Britain and the united States and without their help or French concurrence, they were powerless.

o'Neill had an interview with Salah ben Youssef in which they discussed different aspects of party policy and attitudes which, to some extent, were a reaffirmation of already known ideas. Ben Youssef was at that time more militant than other top nationalist leaders and was closely watched by the Erench, who thought him the likely successor to Bourguiba should anything happen to the latter. Ben Youssef told O'Neill that the party had two projects for the immediate future. One was to work on strengthening itself internally and on organizing for posible action along "maquis" lines when the war finished. The other was to send a top notch representative to Cairo to carry out anti-French activity. O'Neill mentioned how the Destourians had already attempted to send a representative and to obtain united States aid. Ben Youssef confirmed that they were still 
determined to do this and, in fact, a few students had already left the country via Libya in secret several months before and were now in Cairo where they were to make contact with young Algerians and Moroccans who had been there since before the war. (78)

For his part, Mast still refused to recognize Tunisian aspirations. At the final meeting of the Grand Conseil, which had been considering the 1945 budget, the Vice-President of the Tunisian Section, Tahar ben Amar, again, as he had at the opening session, asked for democratic liberties for the Tunisian people and for more internal self-government. (79)

General Mast replied that the Protectorate "from the beginning had been established on a permanent basis." (80) There was a great deal of comment that the Vice-President, who had been considered a French stooge, had spoken out as forthrightly for extensive concessions. Some thought he had been put up to it by General Mast in order that the latter could silence all speculation by his answer. Others thought it more likely that he had been prompted by his colleagues on the Tunisian Committee of Seven. (81)

While Mast's reply was well received by most of the French residents, it was bitterly criticized by the nationalists who were especially upset by Mast's use of the word "permanent." Mast said,

Although this question (Tunisian aspirations) is not within the jurisdiction of the Grand conseil since it has been raised gentlemen, I don't want to leave any doubts in your mind. . 
other French Government spokesmen have already drawn your attention to the fact that a protectorate was not a mandate and that the French Protectorate was, from the beginning, established on a permanent basis. (82)

Furthermore, Mast went to great lengths to make it appear to the outside world that the Tunisians were content with this permanent arrangement. The British consul told O'Neill that he had seen no nationalist leaders for a while but, when he did see Bourguiba, he suggested, after telling him that no British support could be expected for nationalist agitation, that the party would better occupy itself in preparing its case for the peace conference. The Destourians, since they were outlawed, expected no such opportunity and complained that France had for some while been gathering as much evidence as possible to prove, when the matter arose, the attachment of the colonial subjects to France. To counteract this was another reason the Destourians wished to send a spokesman to Cairo. (83)

To prove this attachment of the Tunisians to France, all the newspapers had been publicizing telegrams received from civil controllers in different parts of Tunisia expressing gratitude and happiness to Mast for his reforms. All the telegrams had approximately the same date and O'Neill learned that they were sent in response to instructions from the Residency. The way this worked was for the controllers to assemble the leading Tunisians such as caids and shaikhs and read them a summary of the reforms and then recommend that they send telegrams on behalf of the 
assembled group. Presumably these messages were for external use to prove that the Tunisians were fully and loyally attached to the protecting power. (84)

Mast outlined his long range political, social, and economic plans for Tunisia in a broadcast on February 17 , 1945. Politically the reforms were to permit the Tunisians to participate more in the government and administration of the country. Socially and economically there were plans for more schools, better medical care, and new building programs. As envisioned by Mast, the reforms would require twenty to fifty years and large sums of money. Mast "emphasized that all reforms would be carried out within the framework of the French community and under the Protectorate." (85)

After Mast's speech sixty-eight Tunisians of different political parties met and denounced the reforms as "insufficient and illusory." (86) This group was an enlargement of the Committee of Seven which had met during the past few months to obtain agreement on their political aspirations. Representatives from all Tunisian political parties and independent groups attended including the old Destour, Neo-Destour, the Tunisian Section of the Grand Conseil, Chamber of Commerce and Chamber of Agriculture, professors from the Grande Mosquée, college Sadike and College Alaoui, businessmen, and landowners.

At the meeting a motion was read requesting internal self-government with a popularly elected assembly. The 
Committee of seven had already approved this motion. Some of the group thought that the motion did not go far enough and wanted complete independence with integration of Tunisia in an independent North African Federation, and then into a larger pan-Arab federation. Both the old and New Destour leaders, however, said this was not a good time to raise the question of complete independence as it would hinder the war effort of the United Nations. Furthermore, internal self-government was a necessary step before external sovereignty could be thought of. (88)

It was clear to the participants at the meeting that outside pressure would be needed if Tunisian aspirations for self-government were to be met. They also believed that it was important that the sacrifices of the Tunisians for the war effort, particularly in troops, be credited to the Tunisians and not to France; and that the

claims for self-government be presented to the outside world independent of ideology and passion for the world must know that these claims are based not on fanaticism or xenophobia but on the need for more self respect, liberty, better food and living conditions. These needs are not met by France which not only humiliates and represses us but prevents us from advancing in education, agriculture, and technical fields. (89)

The meeting agreed to form four study groups to work out a detailed plan for self-government with commissions for political and legislative problems, economic and financial problems, educational and cultural problems, and social problems. O'Neill pointed out that nationalist parties had formerly concentrated on political aims and had been vague 
about details of administrative, social, and economic matters. (90)

Mast, several days later informed Tahar ben Amar, the Vice-President of the Tunisian Section of the Grand Conseil, who had in the past been agreeable to French directives, that he, Mast, was "most displeased" (91) with the activities of the meeting, and that no more of these illegal meetings should take place, and that the leaders would be confined if it continued. A second meeting was cancelled.

O'Neill wrote of an article in Nahda about a conversation between its director and General Mast on the reforms planned by Mast. In parentheses O'Neill explained that Nahda and the other Arabic daily, Zohra, were both censored and under a certain "amount of control and suggestion from the Residency," (92) but Nahda to the extent allowed, was more representative of nationalist opinion. It was believed that the interview was initiated by the Resident General in order to allow Tunisian critics who thought the reforms did not go far enough "to let off a certain amount of steam" (93) and to allow Mast to say these reforms were planned steps that, when finished, would be followed by others.

In talks with some of the leaders of the Neo-Destour, O'Neill was told that the party policy for the time being was one of "wait and see." (94) while a minority wanted to act now in hopes that demonstrations and their repression would elicit the sympathy and action of Great Britain and 
the United States, the majority were for waiting in hopes that the San Francisco Conference scheduled for April 25, 1945 would result in some colonial agreement favorable to the Tunisians. They were looking for the support of independent Middle Eastern countries, especially Egypt, at the conference.

The Destourians continued to insist that they would get an important leader to cairo in the near future. Bourguiba was now limited to the city of Tunis proper by the security authorities, and his colleagues claimed that this was because the French were afraid that he would be the one to attempt to leave the country or, should he be permitted to come and go freely, he would conduct a campaign in the interior against the reform plan of General Mast. (96)

April 9, the anniversary of the Tunisian nationalist demonstrations of 1938 after which the French legally dissolved the Destourian parties, was quiet without any incidents. The French police patrolled the streets and Sengalese troops, as well as the American military police, were put on alert. Several inflammatory bulletins were passed around before April 9 and a few were posted on walls around the Grande Mosquée where the students were a focal point for nationalist loyalties. Nationalists reported that some French "agents provocateurs" were trying to promote demonstrations. The Neo-Destourian party, however, had asked its members to remain quiet and avoid any open action. The native quarter appeared normal during the day. 
This peacefulness was not unexpected. The nationalist leaders had often assured the Americans and British that they would refrain from any active disturbances that might hurt the war effort. They knew that any disturbances would be quickly put down by the French authorities and would be disapproved by the United States or Great Britain. (98)

While the peacefulness of April 9 was expected, the vast outpouring of grief at the time of Roosevelt's death on April 12 was not. The extent of Tunisian mourning came as a real surprise to the French. The nationalists looked up to him because he had espoused self-determination in the Atlantic Charter, and they organized a mammoth parade of mourning. Demonstrations had previously not been allowed, but this ceremony of mourning was allowed on this day. There was great fervor and shouting. It was a memorable occasion that really startled the French and frightened them since it was the first time that they saw the dimensions of the nationalist movement. O'Neill described it saying, "You could hear the shouts. There was peaceful marching in ordered ranks. There were rows and rows - thousands." (99) It gave the nationalists a sense of their own strength and was a real shot in the arm for them. The French were alarmed, but O'Neill was not sure what their reaction was or what they did in retaliation. (100)

O'Neill reported on a couple of minor incidents that happened at the memorial ceremony which involved Tunisians. In one, Tunisian students marched around with a sign in 
Arabic saying "Glory to the Great President Roosevelt, creator and Guiding spirit of the Atlantic Charter." (101) French authorities watched them carefully to make sure no unanticipated demonstration took place as a result of this group. Another minor incident was over the report of a French newspaper that "several Tunisian religious organizations took part" (102) in the memorial ceremony. The Tunisian press was indignant because all sections of the Tunisian population had taken part with great enthusiasm. (103)

When it was learned that Habib Bourguiba had disappeared, there was much discussion. It was rumoured that he had been whisked away by the French, as a precaution before April 9, or that he had left secretly for Egypt, which he had wanted to do in order to promote Tunisian nationalist aspirations. (104)

The rumour that Bourguiba had escaped to Egypt was indeed true. When the French had refused to allow him to go to his niece's wedding in his native village of Monastir, it was the "final blow," (105) and he decided to go anyway. His car was sent empty to Monastir while he remained "ostentatiously in Tunis." (106) Then, taking a mianight train to Sfax, he mixed with a group of Tunisian students and arrived at Monastir where a group of Destourians ready to fight kept the police from arresting him. The Tunisian governor of the district advised the local French controller not to start riots by keeping Bourguiba from going to the 
wedding so he was permitted to attend and to return to Tunis by car. In Tunis his comrades told him his escape had been arranged. He was to leave his car conspicuously parked in front of his house and go to a hiding place. (107)

From his hiding place he went on March 26 to Sfax where, disguised as a fisherman, he took a sailing ship to a small port in Tripolitania. The trip took almost a week and at one point the ship was becalmed for three days within sight of Gabes. Bourguiba spent his time below deck. In Tripolitania he bought native clothes and was able to join the party of a shaikh going to Benghazi. From there his trip was by camel, donkey, and on foot for sixty kilometers until he passed the Egyptian border where he was arrested on April 26, one month after leaving Tunis. His release was arranged through the Secretary General of the Arab League and the British immigration authorities allowed him to remain indefinitely. (108)

In Egypt Bourguiba saw advocates of the Arab League and other groups concerned about their North African brethren. He also contacted Doolittle and on May 15 he visited the Alexandria consulate and recounted his story. Doolittle told Bourguiba to take up with the Legation any political matters that he could not handle himself. In his despatch Doolittle wrote,

I hope that he may be accorded a hearing. Habib Bourghiba is a most interesting man. A fanatic in defense of his ideals of national autonony. I have found him to be straight and direct beyond the conception of any other oriental 
politician. Slight of figure with blazing blue eyes, he is the type that lives on nervous energy and inner convictions. (109)

Doolittle's youngest daughter, Natasha, who joined her parents in Egypt in 1945, recalled that Bourguiba had come twice for lunch. Her father saw that Bourguiba was not the unscrupulous agitator the French portrayed, but a man devoted to his country. (110)

When Mast learned of Bourguiba's arrival in Egypt and meeting with Doolittle, he lost no time in telling o'Neill that he was afraid that the friends of Bourguiba might try to send messages to him through the American Consulate and that he would view seriously any such help to the nationalists by the United States. O'Neill assured him that "it was established policy not to accept such material from any source." (111)

In his anxiety about Bourguiba and Doolittle, Mast must have again asked the French Embassy in Washington to intervene. The Counselor from the latter spoke to Loy Henderson in the Bureau of Near Eastern Affairs of the State Department about the fact that Doolittle

had been encouraging Tunisian revolutionists who had taken refuge in Egypt and in particular had been giving encouragement to Mr. Habib Bourguiba, one of the most notorious of the Tunisian revolutionary leaders. (112)

Henderson told the counselor that "after investigating the matter the Department was convinced that Doolittle was not assisting or encouraging Tunisian revolutionists."

Doolittle "had been in the Foreign Service for many years 
and his record was such that the Department had confidence in his integrity and judgment." (114)

Because he feared Henderson was "fed up" (115) with his complaints, several weeks later the same counselor approached another member of the state Department with reports of frequent contacts between Doolittle and Bourguiba along with a report that Bourguiba's journey to Egypt had been arranged by Mrs. Doolittle. The Counselor was told that the story about Mrs. Doolittle was absurd and "that all of these reports bore the stamp of overzealousness on the part of some agent." (116)

It was not only Doolittle that Mast worried about, but any contacts by the Americans or British with the Tunisians. Mast expressed a concern to O'Neill about the activities of OSS and JICA representatives in Tunisia, saying they were interfering with the internal affairs of the country. O'Neill believed Mast's complaints were unfounded and represented only a general concern about foreign aims in North Africa. (117)

Mast was worried about Doctor Frend, a member of the British Psychological Warfare Board, who thought that the administration of Tunisia was too heavy a burden for the French and that the troubles in Tunisia could only be remedied by replacing the Bey's ministers with members of the Destour who enjoyed the confidence of the Tunisians. Frend thought an interallied commission should be formed to study and find solutions to the Tunisian problems. Frend had 
been in touch with Ben Youssef and Bourguiba through the intermediary of SIim Driga "ancien secretaire de M. Doolittle." (118) Mast thought it was important to call these "agitations" to the attention of the British and have him recalled from Tunisia. (119)

On a trip to Paris Mast met with Malige, now Counselor for Economic Affairs at the American Embassy, to complain of a certain oss agent who was consorting with a notorious Arab prostitute. He ended by saying "with a smile" that this was "the only problem of importance which existed in the relations between the United States and the French Protectorate of Tunisia." (120)

Mast's overzealousness may have been partly due to his own personality, formed by a military career, which could not tolerate any threats to his authority. John Utter, who was also working in Paris, saw Henri Gantes, a French controller from sfax, who explained why he had refused the job offered to him by Mast as Chef du Cabinet. In giving his reasons, he was very critical of Mast who, he thought, saw everything from a military point of view. He considered Mast to be too rigidly maintaining an outdated colonial system.

He is not in agreement with the General's Arab policy. - Gantes was born and brought up in Egypt, has a thorough knowledge of the English treatment of this moslem country and is definitely inclined to such methods for French North Africa. He fears strongly that France is not keeping pace with the world-wide evolution of colonial policy and is sure to run into trouble if definite actions and unselfish gestures are not substituted for fine yet vague words. The top-heavy structure of Functionnaires in the Regency appalls him. 
Gantes does not want to work closely with a man who views everything from a purely military angle, and he feels that Mast does not listen to advice. (121)

While Mast may have had such limitations, his policy simply reflected that of the de Gaulle administration and the very nature of colonialism. The watchword of the de Gaulle administration was maintenance of the colonial status quo. This stemmed from its own weakness. The Committee, later the Provisional Government, could not afford to alienate the large landholding colonialists and industrialists in the colonies, who, of course, had always felt threatened by any hint of change or liberalization that might benefit the Tunisians. The Committee itself included members formerly connected with big business and the army. Naturally, the Committee stuck to the traditional colonial line. Even if members of the Committee had wanted to change that line, the committee was too preoccupied with attempting to strengthen itself internally and establishing itself as the representative of France to begin new programs.

De Gaulle's anticipation of France's post-war situation was a major factor in his colonial policy. He felt in order for France to regain its position as a first rate power, it needed the Empire, and he did not wish to give the colonial peoples the slightest hope of independence. This rigid policy probably came from the fear that colonies might break away if given any privileges while France was in such a weak position. Preserving the greatness of France was the dominant idea of all the Gaullists. Macmillan described the 
French attitude in the fall of 1943:

They are really as touchy as a divorced woman about their 'reputation' and their 'position in European society'. If they could get a ticket for the Great Powers Enclosure they would be happy. (123)

The French bureaucracy was composed of officials, many of whom had held their posts since before the war. Since their major concern was their pensions, it was not surprising that they didn't want to give up the traditional colonial policy for some new liberal ideas. Furthermore, the bureaucracy contained many pro-Vichyites who were motivated by hanging-on rather than introducing new ways. (124)

The very nature of colonialism was at the heart of the problem. Memmi in Portrait du Colonisé, precede du Portrait du Colonisateur described how the colonizer became a reactionary, even a fascist, since he had no choice but to approve the discrimination and codification of injustice. The colonizer worried whenever any political change was suggested and could support only governments that were oppressive and reactionary or at least conservative. (125)

According to Memmi, racism symbolized the fundamental relation between the colonizer and the colonized. The colonized had lost the habit of active participation in government. At first the colonized attempted to imitate the colonizer, but, in this attempt at assimilation, he was denying himself and his traditions. The next step was to revolt. Memmi did not think it was a coincidence that many colonial leaders, such as Bourguiba, had mixed marriages. 
Having pushed the attempt at assimilation to its limit, they had returned to their own base and to the realization that their own future coincided with that of their people. (126) While still imprisoned in Marseille, Bourguiba had written his intimates that the colonized had a responsibility for his servitude. The first thing he needed to do was to become aware of the mediocrity of his condition and the pride of being liberated from it. "The day when the colonizer will have been delivered from his complex of dominator and the colonized from his complex of servitude, colonialism will have seen its end." (127)

It was the colonial system that was at the heart of the problem between Doolittle and Murphy as well as between de Gaulle and Roosevelt. Even if Roosevelt and de Gaulle had been able to meet again and perhaps overcome personality problems, there would have remained their fundamental difference over colonialism. The reason De Gaulle refused Roosevelt's invitation to meet in Algiers was a demonstration of this. De Gaulles' readiness to take as an insult Roosevelt's inviting him to the same cruiser on which he had talked with the presidents of Syria and Lebanon shows something of his touchy attitude of superiority toward these colonials.

For his part Murphy took the side of the French. Since he had been the counselor of the Embassy in Paris before coming to North Africa, he was, perhaps, in the habit of identifying with French goals. Because of his role in 
obtaining French help for the North African invasion and then keeping it during the Tunisian campaign, it was understandable why he avoided consideration of Tunisian goals.

Murphy had his critics. Roosevelt received several letters and telegrams complaining about his appointment of Murphy as Ambassador to Germany in the fall of 1944. One telegram suggested that Roosevelt would be hurt in his campaign for reelection by his appointment of Murphy. A letter entered a protest against Murphy's appointment because of his record which was "at such variance with the Democratic Ideals expressed by you [Roosevelt] and longed for by most people." (128) Another letter suggested that Murphy was being appointed only because of "personal appearance and handsome social manners." (129)

It would seem that Doolittle might have resented Murphy's part in his recall. According to his daughter, Katya, however, this was not the case. Katya indicated that he continued to feel friendly towards Murphy. Paul O'Neill, who later served with Murphy in Brussels, thought this was not surprising because Murphy was very affable. Possibly Doolittle was unaware of the case Murphy built up against him and thought it was primarily the influence of Mast on Eisenhower that had caused his withdrawal.

Roosevelt and Doolittle shared similar beliefs about carrying out the goals of the Atlantic Charter. Roosevelt envisioned a world without colonialism with trusteeships for 
former colonies serving as an intermediary stage. He would have Iiked French Indochina to have been one of these. One of the reasons he had tried to block de Gaulle from power was because of the latter's wish to restore France and its Empire to its former glory. Not only did Roosevelt not succeeed in preventing de Gaulle from taking power, in retrospect it was obvious that he had far less influence on the French than he thought he should have.

Iike Roosevelt, Doolittle thought the United states could influence French policy. Military necessity was the reason for not interfering. While this may have been sufficient reason during the war, it need not have kept the United states from lending a sympathetic ear to the problems of the North Africans and attempting to understand their nationalist goals.

This was what Doolittle had done. In a letter to another Foreign Service officer, Doolittle speculated that his outspokeness had hindered his advancement in the state Department. Doolittle wrote that his own career was

marred and often retarded by an unfortunate propensity for expressing what I believed in the interests of the country rather than what the powers that be in the Department wished to have reported. (130)

Doolittle was Minister to Pakistan when he retired to live in Tangier. In his letter he told the friend if he came to Tangier to

Go to Cape Spartel and turn left into the valley. Look for a vine covered stone hut surrounded by some straggling weeds and a bench where a aisreputable elderly native is 
trying to catch a prawn for a frugal supper. Him, the native will be me - ex F.S.O. (131)

While Doolittle's career advancement may have been hindered by his forthrightness, he did receive the Medal of Freedom for

his active and successful role in the work of preparation for the landing of Allied forces in French North Africa. Speaking the French and Arabic languages, Mr. Doolittle was able successfully to establish useful contacts with the resistance movement in French Morocco and Tunisia and to assist in counteracting the subversive activities of the German and Italian Armistice Delegations and their agents operating in that area. (132)

Bourguiba credited Doolittle's intervention on his behalf in 1943 for saving the Neo-Destour from oblivion. On June 7,1966 , the anniversary of the date that Bourguiba was given his freedom, Bourguiba honored Doolittle at a celebration in Tunis. At that time Bourguiba recalled in a radio address the help Doolittle had given him. Only recently Doolittle's daughter, Katya, and granddaughter were welcomed by Bourguiba and his wife on a visit to Tunisia. On that visit they discovered that there was a Hooker A. Doolittle street in Tunis.

The fact that Tunisia obtained independence without bloodshed may perhaps be attributed to Bourguiba's patient and sensible guidance. In his radio broadcast of June 7 , 1966 he stated

We were able to disengage ourselves from a difficult situation by using audacity, suppleness and perseverance.

Bourguiba continued that was the method of fighting which 
had always succeeded for them. By his help and encouragement Hooker Doolittle had played a role in that successful fight. 
NOTES

CHAPTER VIII

1. Malige to Hull, July 15, 1944, 851S.00/7-1544.

2. Ibid.

3. Ibid.

4. Ibid.

5. De Gaulle, Mémoires de Guerre: Le Salut, 223.

6. Quoted in Malige to Hull, May 8, 1944, 8515.00/320.

7. Ibid.

8. Interview in Libération, October 7, 1944 transmitted in Malige to Hull, November 10, 1944, 851S.00/11-1044.

9. Ibid.

10. Ibid.

11. Ibid.

12. Ibid.

13. Ibid.

14. Ibid.

15. Ibid.

16. Ibid.

17. Malige to Hull, February 23, 1944, 8515.00/302.

18. Malige to the author, February 24,1984 .

19. Malige to Hull, February 23, 1944, 8515.00/302.

20. Ibid. 
21. Ibid.

22. Ibid.

23. Ibia.

24. Ibid.

25. Ibia.

26. Malige to Hull, May 5, 1944, 851s.00/319.

27. Ibid.

28. Ibid.

29. Ibid.

30. Ibid.

31. Ibid.

32. Ibid.

33. Ibia.

34. Malige to Hull, October 25, 1944, 8515.00/10-2544.

35. Ibid.

36. Ibid.

37. Ibid.

38. Ibid.

39. Ibid.

40. Malige to Hull, October 2, 1944, 8515.00/10-244.

41. Malige to Hull, November 13, 1944, 851S.00/11-1344.

42. Mast to Massigli, March 1944, vol. 908, Quai d'orsay. d'orsay.

43. Monthly Report by Mast, March 1944, vol 865, Quai

44. Ibid, May 1944.

45. Ibid, March 1944. 
46. Malige to Hull, August 7, 1944, 8515.00/8-744.

47. Excerpt from Alexandria Consulate's Political Review (Doolittle), June 2, 1945 transmitted by $S$. Pinkney Tuck to Hul1, June 9, 1945, 890B.00/6-945.

48. Cole to Hull, January 18, 1944, 8515.00/298.

49. Malige to Hull, October 23, 1944, 8515.00/10-2344.

50. Malige to the author, February 24, 1984.

51. Malige to Hull, January 16, 1945, 8515.00/1-1645.

52. Ibid.

53. Mast to Massigli, September 16, 1943, vol. 866.

54. Macmillan, War Diaries, 264.

55. Ibid.

56. Ibid.

57. Ibid.

58. O'Neill to Hull, January 29, 1945, 8515.00/1-2945.

59. Mast to Massigli, August 1944, vol. 865.

60. Malige to Hull, November 27, 1944 , $8515.00 / 11-2744$.

61. Ibid.

62. Murphy to Hull, October 30, 1944, 8515.00/10-3044.

63. Murphy to Hul1, October 17, 1944,851s.00/10-944.

64. Stimson Diary, September 14, 1944.

65. Malige to Hull, May 8, 1944, 8515.00/321.

66. Ibid, June 17, 1944, 8515.00/6-1744.

67. Ibid.

68. Ibia.

69. Ibid.

70. Dallek, Franklin D. Roosevelt and American Foreign Policy 1932-1945, 367 . 
71. Malige to Hull, October 30, 1944, 851s.00/10-3044.

72. Interview with O'Neill, December 11, 1983, Bethesda, Maryland.

73. Ibid.

74. O'Neill to Hull, February 6, 1945, 8515.00/2-645.

75. Dallek, Franklin D. Roosevelt and American Foreign Policy 1932-1945, 510, 512 .

76. De Gaulle, Mémoires de Guerre: Le Salut, 88.

77. Ibid.

78. O'Neill to Hull, January 29, 1945, 8515.00/1-2945.

79. Ibid, January 22, 1945, 8515.00/1-2245

80. Ibid.

81. Ibid.

82. Ibid.

83. O'Neill to Hull, January 29, 1945, 8515.00/1-2945.

84. O'Neill to kull, March 26, 1945, 8515.00/3-2645.

85. O'Neill to Hull, February 19, 1945, $8515.00 / 2-1945$.

86. O'Neill to Hull, February 28, 1945, $8515.00 / 2-2845$.

87. Ibid.

88. Ibid.

89. Ibid.

90. Ibid.

91. Ibid.

92. O'Neill to Hull, March 15, 1945, 8515.00/3-1545.

93. Ibid.

94. O'Neill to Hull, March 26, 1945, 8515.00/3-2645. 95. Ibid. 
96. Ibid.

97. O'Neill to Hull, April 10, 1945, 8515.00/4-1045.

98. Ibid.

99. Interview with O'Neill, December 11, 1983, Bethesda, Maryland.

100. Ibià.

101. O'Neill to Hull, April 25, 1945, 851S.00/4-2545.

102. Ibid.

103. Ibid.

104. O'Neill to Hull, April 10, 1945, 8515.00/4-1045.

105. Excerpt from Alexandria Consulate's Political Review, June 2, 1945, transmitted by S. Pinkney Tuck to Hull, June 9, 1945, 890B.00/6-945.

106. Ibid.

107. Ibid.

108. Ibia.

109. Ibid.

110. Telephone interview with Natasha Van Deusen, November 15, 1983.

111. O'Neill to Hull, May 18, 1945, 851S.00/5-845.

112. Loy $W$. Henderson, State Department Memorandum of Conversation, September 24, 1945, 851S.00/9-2445.

113. Ibid.

114. Ibia.

115. G. P. Merriam, State Department Memorandum of Conversation, November 1, 1945, 851S.00/11-145.

116. Ibid.

117. O'Neill to Hull, July 19, 1945, 8515.00/7-1945.

118. Mast to Massigli, February 9, 1944.

119. Ibia. 
120. Hugh S. Fullerton to Hull, August 25, 1945, $851 \mathrm{~S} .00 / 8-2545$.

121. O'Neill to Hull, July 19, 1945, 8515.00/7-1945.

122. R\&A 1469.

123. Macmillan, War Diaries, 122.

124. R\&A 1469.

125. Albert Memmi, Portrait du Colonisé, précédé du Portrait du Colonisateur (Paris: n.p., 1957), 76-86.

126. Ibid, 176-177.

127. Quoted in Felix Garas, Bourguiba et la Naissance d'une Nation (Paris: n.p., 1956), 11.

128. H. I. Pommer to Roosevelt, September 6, 1944, Roosevelt Library, Hyde Park, New York.

129. J. C. Carter to Roosevelt, September 4, 1944, ibid.

130. Doolittle to Ray Thurston, September 10, 1949 , Katya Coon.

131. Ibid.

132. War Department, Citation of Medal of Freedom, Katya Coon.

133. "Le Président Bourguiba Retrace Les Événements du 7 Juin 1943," June 8, 1960. 
BIBIIOGRAPHY

PRIMARY SOURCES

\section{Manuscript Sources}

Leahy, William D. Manuscript Diary. Library of Congress, Washington, D.C.

Papers deposited in the Archives du Ministere des Affaires Etrangeres, 37 Quai d'orsay, Paris, France.

President's Secretary's File. Franklin D. Roosevelt Iibrary, Hyde Park, New York.

Research and Analysis Reports of the organization of Strategic Services deposited in the National Archives, Washington, D.C.

State Department Papers deposited in the National Archives, washington, D.C.

Stimson Diary, Yale University, New Haven, Conneticut.

\section{Published Sources}

Bullitt, Orville H., ed. For the President: Personal and Secret Correspondence Between Franklin D. RooseveIt and William C. Bullitt. Boston: Houghton Miffin Company, 1972.

Butcher, Harry C. U.S.N.R. MY Three Years with Eisenhower. New York: Simon and schuster, 1946.

Chandler, Alfred D., ed. The Papers of Dwight David Eisenhower. Baltimore: Johns Hopkins Press, 1970. VOIS. I and II.

Churchill, winston $S$. The second world War: The Hinge of 
Fate. Boston: Houghton Mifflin, 1950.

Clark, Mark W. Calculated Risk. New York: Harper, 1950.

Coon, Carleton S. Adventures and Discoveries: The

Autobiography of Carleton S. Coon, Anthropologist and Explorer. Englewood, New Jersey: Prentice Hali, 1981.

OSS A North African Story: The Anthropologist as 1980.

Cooper, Duff (Viscount Norwich). Old Men Forget. London: Rupert Hart-Davis, 1954.

Crusoé (Jacques Lemaigre-Dubreuil). Vicissitudes d'une Victoire. Paris: Les Edition de I'Ame Française, 1946.

De Gaulle, Charles. Mémoires de Guerre: 3 vols. (L'Appel, L'Unité, Le Salut). Paris: Librairie Plon, 1954.

Department of state. Foreign Relations of the united States, Diplomatic Papers, 1940, II. Washington, D.C.: United states Government Printing office, 1957.

- Foreign Relations of the United states, Diplomatic Papers, 1941, II. Washington, D.C.: united states Government Printing office, 1959.

- Foreign Relations of the United States, DiplomaEic Papers, 1942, II. Washington D.C.:

United states Government Printing office, 1962.

Foreign Relations of the United States: The Conferences of Washington, 1941-1942 and Casablanca, 1943, washington D.C. United States Government Printing office, 1968.

Dodas-Parker, Douglas. Setting Europe Ablaze: Some Accounts of Ungentlemanly Warfare. Windlesham, Surrey: Springwood Books Limited, 1984.

Eisenhower, Dwight. Crusade in Europe. Garden City, New York: Garden City Books, 1948 .

Hull, Cordell. The Memoirs of Cordell Hull. 2 vols., New York: Macmilian, 1957-8.

Juin, Alphonse. Mémoires: Alger, Tunis, Rome. Paris: Librairie Artheme Fayard, 1959-60.

Knaplund, Paul. Letters from the Berlin Embassy 1871-1874. 3 vols., of Annual Report of the American Historical Association 1942. Washington D.C.: Government Printing 
Office, 1944 .

Leahy, william D. I was There. New York: Whittlesey House, 1950 .

Macmillan, Harold. The Blast of War 1939-1945. London: Harper and Row, 1967 .

Macmillan, Harold. War Diaries: Politics and War in the Mediterranean January 1943-May 1945. New York: St. Martin's Press, 1984.

Mast, Charles, Histoire d'une Rébellion: Alger 8 Novembre 1942. Paris: n.P., 1969.

Murphy, Robert. Diplomat Among Warriors. Garden City, New York: Doubleday, 1964 .

Pendar, Kenneth. Adventures in Diplomacy. New York: Dodd, Mead and company, 1945.

Roosevelt, Eleanor. This I Remember. New York, Harper, 1949.

Roosevelt, Elliot. As He Saw It. New York: Duell, Sloan and Pearce, 1946 .

Roosevelt, Elliot, ed. F.D.R.: His Personal Letters

1928-1945. 4 vols., New York: Duell, Sloan and Pearce, $1947-50$.

Rosenman, Samuel I., ed. The Public Papers and Addresses of Franklin D. RooseveIt. XI, New York: Harper, 1938-1950.

Sherwood, Robert $E$. Roosevelt and Hopkins: An Intimate History. New York: Harper and Brothers, 1948.

Stimson, Henry and McGeorge Bundy. On Active Service in Peace and War. New York: Harper, 1948.

Weygand, Maxime. Recalled to Service. Garaen City, New York: Doubleday, I952.

Interviews, Letters and Miscellaneous

Bourguiba, Habib. Letter to Franklin D. Roosevelt, June 7, 1943, transmitted by Hooker Doolittle. In the possession of Katya Coon, Marshfield, Massachusetts. 
Radio Interview. "Le President Bourguiba Rétrace Les Evénements du 7 Juin 1943. "Printed in La Dépêche Tunisienne, June 8,1960 . In the possession of Katya Coon, Marsheield, Massachusetts.

Carter, J.C. Letter to Franklin Roosevelt, September 4, 1944. Roosevelt Library, Hyde Park, New York.

Coon, Katya. Interview, December 10, 1983, Marshfield, Massachusetts.

............. Telephone interview, August 4, 1985.

Doolittle, Hooker. Essay. "L'Affaire Doolittle." Undated. In the possession of Katya Coon, Marshfield, Massachusetts.

1949. In the possession of Katya coon, Marshfield, Massachusetts.

Malige, Marcel. Letter to author, February 24, 1984.

O'Neill, Paul. Interview, December 11, 1983, Bethesda, Maryland.

Pommer, H.I. Letter to Franklin Roosevelt, Septermber 6, 1944. Roosevelt Library, Hyde Park, New York.

Van Deusen, Natasha. Telephone interview, November 15, 1983.

War Department. Citation of Medal of Freedom. In the possession of Katya Coon, Marshfield, Massachusetts.

\section{SECONDARY SOURCES}

Books

al-Fasi, Allal. The Independence Movements in North Africa. Translation Hazem Zaki Nusiebeth. American Council of Learned Societies, 1954.

Aron, Robert. The Vichy Regime 1940-44. New York: Macmillan, 1958.

Barbour, Nevill, ed. A Survey of North west Africa (The Maghrib). Oxford: Oxford University Press, 1959.

Berque, Jacques. French North Africa: The Maghrib Between 
Two World wars. Translated by Jean Stewart. London:

Frederick A. Praeger, 1967.

Blair, Leon Borden. Western window in the Arab World.

Austin: University of Texas, 1971.

Coles, Harry L. and Albert $K$. Weinberg. Civil Affairs:

Soldiers Become Governors. Washington, D.C.: Office of

the chief of Military History Series, United states

Army in world War II. Department of the Army, 1964.

Dallek, Robert. Franklin D. Roosevelt and American Foreign Policy 1932-1945. New York: Oxford University Press, 1979 .

De La Gorce, Paul-Marie. The French Army. Translated by Kenneth Douglas. New York: George Braziller, Inc., 1963.

Dougherty, James J. The Politics of Wartime Aid: American Economic Assistance to France and French West Africa

1940-1946. Westport, Conneticut: Greenwood Press, 1978 .

Duroselle, Jean-Baptiste. France and the united States: From the Beginning to the Present. Chicago: University of Chicago Press, 1978 .

Feis, Herbert. Churchill, Roosevelt, Stalin: The war They Waged and the Peace They Sought. Princeton: Princeton University Press, 1967.

Funk, Arthur I. Charles de Gaulle: The Crucial Years 1943-1944. Norman: University of Oklahoma Press, 1959.

The Politics of Torch: The Allied Landing and the Algiers Putsch, 1942. Lawrence: University Press of Kansas, 1974 .

Gallagher, Charles F. The United States and North Africa: Morocco, Algeria and Tunisia. Cambridge: Harvard University Press, 1960.

Garas, Felix. Bourguiba et la Naissance d'une Nation. Paris: $\mathrm{n} \cdot \mathrm{P} ., 19 \overline{56 .}$

Hahn, Lorna. North Africa, Nationalism to Nationhood. Washington, D.C.: Public Affairs Press, 1960 .

Howe, George F. United States Army in world War I I Northwest Africa: Seizing the Initiative in the west.

Washington, D.C.: Office of the Chief of Military

History, Department of the Army, 1957. 
Hytier, Adrienne D. Two Years of French Foreign Policy Vichy 1940-1942. Geneva: E. Droz, 1958.

Julien, Charles-André. L'Afrique du Nord en Marche. Paris: Rene Juillard, $19 \overline{72 .}$

Kammerrer, Albert. Du Débarquement Africain au Meutre de Darlan. Paris: Flammarion, 1949.

Laffont, Pierre. Histoire de la France en Algérie. n.p.: Librarie Plon, 1980.

Langer, william. Our Vichy Gamble. New York: Knopf, 1947.

Ling, Dwight L. Tunisia from protectorate to Republic.

Bloomington: Indiana University Press, 1967.

Marrus, Michael R. and Robert O. Paxton. Vichy France and the Jews. New York: Schocken Books, 1983.

Maurois, André. A History of France. Translated by Henry I. Binsse. New York: Farrar, Strauss and Cudahy, 1956.

MCNeil, william H. America, Britain and Russia: Their Cooperation and ConfIICt 1941-1946. London: Survey of International Affairs, 1953.

Memmi, Albert. La Statue de sel. Paris: Gallimard, 1966.

Memmi, Albert. Portrait d'un colonisé, précédé du portrait d'un colonisateur. Paris: n.p., I9ST.

Micaud, C.A., Leon Carl Brown, and Clement Henry Moore. Tunisia: The Politics of Modernization. New York: F. A. Praeger, 1964.

Moore, clement Henry. Politics in North Africa: Algeria, Morocco and Tunisia. Boston: Little Brown, 1970.

Paxton, Robert 0 . Parades and Politics at Vichy: the French officer Corps under Marshal Petain. Princeton, New Jersey: Princeton Universiey Press, 1966.

-.... Vichy France: Old Guard and New Order, 1940-44. New York: Norton, 1972.

Renouvin, Pierre. Les crises du XXe Silecle. 2 vols., of Histoire des Relations Internationales, Tome Huitieme. Paris: Hachette, 1957-58.

Salem, Norma. Habib Bourguiba. Islam and the creation of Tunisia. London: Croom Helm, 1984.

Smith, R. Harris. OSS: The Secret History of America's First 
Central Intelligence Agency. Berkeley:

University of California Press, 1972.

Strauss, Davia. Menace in the West: The Rise of French Anti-Americanism in Modern Times - Westport, Conneticut: Greenwood, 1978.

Thomas, R.T. Britain and Vichy: The Dilemma of Anglo-French Relations 1940-1942. New York: St. Martin's Press, 1979 .

Vigneras, Marcel. Rearming the French. Washington, D.C.: United states Government Printing Office, 1957.

Viorst, M. Hostile Allies: FDR and Charles de Gaulle. New York: Macmillan, 1965.

White, Dorothy Shipley. Seeds of Discord: De Gaulle, Free France and the Allies. Syracuse: Syracuse university Press, 1964.

Ziadeh, Nicola A. Whither North Africa. Aligarh, India: Institute of Islamic Studies, 1957.

Articles

Barbour, Nevill. "Variations of Arab National Feeling in French North Africa." The Middle East Journal, 8, 1954 .

"Bourguiba et Doolittle." L'Action, June 5, 1966. In the possession of Katya Coon, Marshfield, Massachusetts.

Brown, Leon Carl. "The United States and the Maghrib." The Middle East Journal, 30, 1976.

"De la Campagne de Tunisie." La Dépêche Tunisienne, June 7 , 1960. In the possession of Katya Coon, Marsheield, Massachusetts.

Funk, Arthur L. "Negotiating the 'Deal with Darlan.'" Journal of Contemporary History, 8:2, 1973.

Julien, Charles-André. "France and Islam." Foreign Affairs, 18, July 1940 .

Lemaigre-Dubreuil, Jacques. "Giraud et de Gaulle a Alger." Revue de Paris, July 1949.

Neville-Bagot, Geoffrey. "Habib Bourguiba, Prime Minister of 
Tunisia: A Portrait of North Africa's Greatest Statesman." The Islamic Review, 44, no. 12, 1956.

Rivlin, Benjamin. "The Tunisian National Movement: Four Decades of Evolution." The Middle East Journal, 6 , 1952 .

Romeril, Paul E.A. "Tunisian Nationalism: A Bibliographical Outline." The Middle East Journal, 14, 1960.

Roosevelt, Franklin D. "Our Foreign Policy: A Democratic View." Foreign Affairs, 6, July 1928.

Smith, Kingsbury. "Unrevealed Facts about Robert Murphy." American Mercury, 59, no. 251, November 1944.

Villard, Henry. "Action in North Africa." American Foreign Service Journal, 19, no. 12, December 1942. 